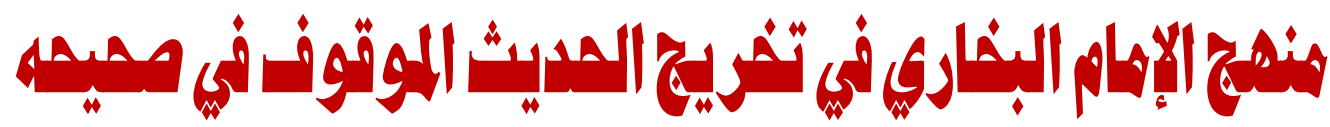 \\ (دراستّ تطبيقيت من كتاب الصلاة إلى نهايت كتاب الجنائز) \\ إعداد \\ د ـ خالد محمهد الشرمان \\ الأستاذ المشارك بقسم أصول الدين

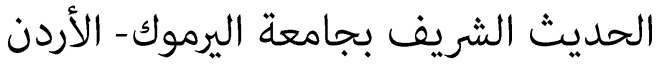

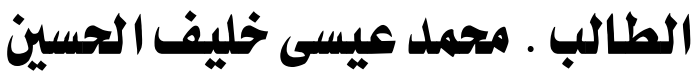

مرحلة الدكتوراة- الحديث الشريف بجامعة اليرموك- الأردن

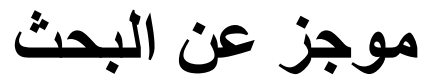

موضوع البحث: تبين هذه الدراسة منهجية الإمام البخاري في تخريج الحديث الموقوف، من حيث أنواعه، وطرق سياقته بإسناده أو تعليقه والسبب الذي من أجله

يقوم بتخريجه، وعلاقته بترجمة الباب وعلاقته بالحديث المرفوع، ودلالته على فقهه.

$$
\text { أهداف البحث: }
$$

ا ـ الكشف عن أسباب ذكر البخاري للحديث الموقوف.

r. الوقوف على منهج البخاري في سياقة الموقوفات.

r. التعرف على منهج البخاري من إسناد الموقوف وتعليقه.

ع . بيان منهج البخاري في علاقة الموقوف بترجمة الباب.

ه . بيان منهج البخاري في علاقة الموقوف بالحديث المرفوع في الباب.

7 ـ استخر اج منهج البخاري في ذكر الموقوفات للاستدلال الفقهي.

منهج البحث: المنهج الاستقرائي والمنهج الاستنباطي 


\section{أهم النتائج:}

ا ـ يخرج البخاري الموقوف الجلي والموقوف الخفي الذي يتميز عن المرفوع

بالقر ائن.

r. يخرج البخاري الموقوف ويترك المرفوع لترجيحه الوقف ، لعلة ظهرت في

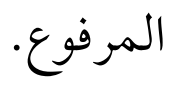

r. العلاقة بين الموقوف وترجمة الباب ذات صلة وثيقة بمقاصد البخاري. ع. العلاقة بين الموقوف والحديث المرفوع في الباب ذات صلة وثيقة بمقاصد

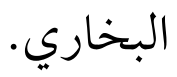

ه. الموقوفات إحدى مصادر فقه البخاري من استنباط الحكم الشرعي

$$
\text { أهم التوصيات: دراسة جميع الأحاديث الموقوفة في صحيح البخاري }
$$

الكلمات المفتاحية: الموقوف، صحيح البخاري، منهج ، تخريج الحديث . 
The Approach Of Imam Al-Bukhari In Graduating The Suspended Hadith In His Sahih An Applied Study From The Prayer Book To The End Of The Funeral Book

Khaled Mohammed Al-Sharman

Muhammad Issa Khleif Al-Hussein

Department of Fundamentals of Religion, The Noble Hadith , Yarmouk University, Jordan

* Corresponding Author E-mail : khalida@yu.edu.jo

\begin{abstract}
:
Research topic: This study shows the methodology of Imam al-Bukhari in producing the waqf hadith, in terms of its types, the methods of its direction with its isnad or suspension, the reason for which he is producing it, its relationship to the translation of the chapter and its relationship to the raised hadith, and its evidence for his jurisprudence.
\end{abstract}

\title{
research aims:
}

1) Exposing the reasons for al-Bukhari's mention of the suspended hadith.

2) Standing on the method of Al-Bukhari in driving the detainees.

3) Knowing the method of Al-Bukhari from the chain of transmission and its suspension.

4) Explanation of Al-Bukhari's approach in the relationship of the detainee to the translation of the chapter.

5) Explaining the method of Al-Bukhari regarding the relationship of the arrested with the hadith raised in the chapter.

6) Extracting Al-Bukhari's method of mentioning the mawqif for jurisprudential reasoning.

Research Methodology: Inductive approach and deductive approach

Main results:

1) Al-Bukhari brings out the clear mawqoof and the hidden mawquf that is distinct from the raised evidence.

2) Al-Bukhari removes the suspended and leaves the suspended one, because it is more likely to be held, due to a bug that appeared in the suspended one.

3) The relationship between the arrested and the translation of the chapter is closely related to the purposes of al-Bukhari.

4) The relationship between the arrested and the hadith raised in the chapter is closely related to the purposes of al-Bukhari.

5) The mawqifat is one of the sources of al-Bukhari's jurisprudence from the deduction of the legal ruling

Main recommendations: Study all hadiths suspended in Sahih Al-Bukhari

key words: Al Mawqouf, Sahih Al-Bukhari, Approach, The graduation of the hadith. 


\section{مقدمة}

الحمد لله و الصلاة و السلام على رسول الله محمد صلى الله عليه وسلم ويعد: إن دراسة الحديث الشريف من أسمى أنواع العلوم وأرفعها مكانة بعد دراسة كتاب الله، وصحيح البخاري من أبرز الكتب الحديثية التي نالت اهتمام العلماء قديمًا وحديثًا، وما زال العلماء ينقبون عن كنوزه، وهذه الدراسة هي نوع من الكشف عن كنوز هذا الكتاب العظيم ألا وهو الحديث الموقوف، فمن خلال هذا البحث نقف على الغايات التي من أجلها أودع الإمام البخاري الحديث الموقوف في صحيحه، والمنهجية التي اتبعها البخاري في هذه الموقوفات، ونسأل الله تعالى أن نقدم هذه الدر اسة طلبًا لمرضاته تعالى، وفائدة لطلبة العلم، والله الموفق.

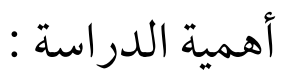

تكمن أهمية هذه الدراسة من خلال النقاط الآتية: ( ) أهمية الحديث الموقوف لعلاقته بالمرفوع من جهات عدة. r) كثرة الحديث الموقوف عند البخاري r)الكشف عن منهج البخاري في الموقوفات. حدود الدراسة : الأحاديث الموقوفة في صحيح البخاري من كتاب الصلاة إلى كتاب الجنائز. مشكلة الدراسة: ويمكن تحديد مشكلة الدراسة من خلال الإجابة عن السؤال

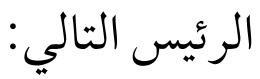

ما منهج البخاري في تخريج الحديث الموقوف في صحيحه. ويتفرع عن هذا السؤال

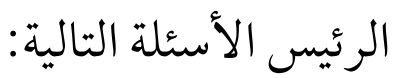




\section{( )ما تعريف الحديث الموقوف، وما أهميته؟}

r) ما أسباب ذكر البخاري للحديث الموقوف؟

r)ما أنواع الموقوف من حيث الظهور و الخفاء ومنهج البخاري فيه؟

ع)ما منهج البخاري في سياقة الموقوفات؟

ه)ما منهج البخاري في تخريج الحديث الموقوف للعلاقة بينه وبين ترجمة الباب

$$
\text { والحديث المرفوع؟ (ب) (ب) }
$$

7)ما منهج البخاري في ذكر الموقوفات للاستدلال الفقهي؟

أهداف الدراسة: وتهدف الدراسة إلى الآتي:

() تعريف الحديث الموقوف، وبيان أهميته.

r) (أسباب ذكر البخاري للحديث الموقوف.

r)أنواع الموقوف من حيث الظهور والخفاء ومنهج البخاري فيه. ع)منهج البخاري في سياقة الموقوفات.

0)منهج البخاري في تخريج الحديث الموقوف للعلاقة بينه وبين ترجمة الباب و الحديث المرفوع في الباب.

7)منهج البخاري في ذكر الموقوفات للاستدلال الفقهي.

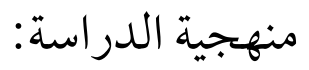

() المنهج الاستقرائي: حيث يتم استقراء جميع الأحاديث الموقوفة من كتاب الصالاة إلى كتاب الجنائز

Y)المنهج الاستنباطي: هو استنباط منهج البخاري في الحديث الموقوف من خلال ما تم دراسته من الأحاديث الموقوفة. 


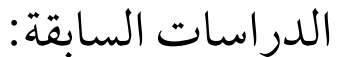

بعد البحث والتفتيش لم أجد بحثًا يختص بفكرتنا هذه إلا أن هنالك عدد من الدراسات التي لها علاقة بدراستي هذه أذكر منها ما يلي: ( )البناء المنهجي للموضوع عند البخاري "كتاب الإيمان نموذجا"، الدكتور خالد

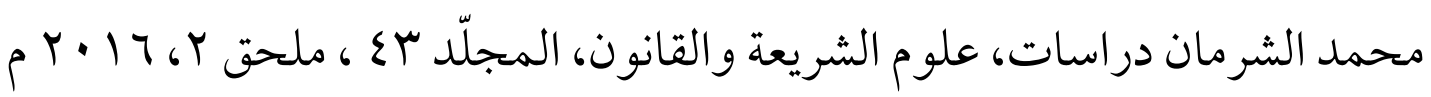
r)سامية توفيق صالح، الحديث الموقوف الذي له حكم المرفوع، مجلة جامعة القرآن الكريم والعلوم الإسلامية، جامعة القرآن الكريم والعلوم الإسلامية - مركز

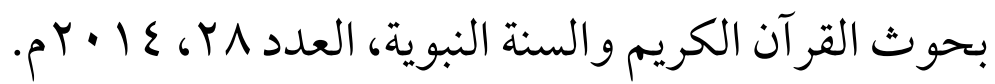
س)عبدالفتاح المبروك الكاسح، قول الصحابي أمرنا أو نهينا بين الرفع و الوقف، مجلة العلوم الشرعية، الجامعة الأسمرية الإسلامية - كلية العلوم الشرعية بمسلاتة، العدد ب، $\cdot r^{r} \cdot 17$

ع)فضلان محمد عثمان وآخرون، الأحاديث الموقوفة التي لها حكم الرفع وحجيتها عند العلماء، مجلة العلوم الإسلامية، ماليزيا، العدد الأول، المجلد الأول، \1 • ب م. وفي جميع الدراسات السابقة لم أجد من بينّ منهج البخاري في الأحاديث الموقوفة 


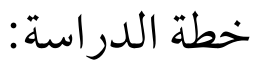

\begin{tabular}{|c|c|}
\hline الحديث الموقوف: تعريفه، وأهميته & تمهيد: \\
\hline المقاصد العامة لذكر البخاري للحديث الموقوف & 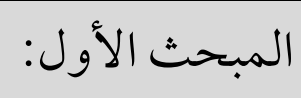 \\
\hline أنواع الموقوف من حيث الظهور والخفاء ومنهج البخاري فيه & 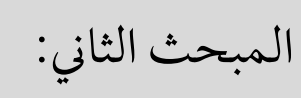 \\
\hline أن يكون الحديث الموقوف جليًا & 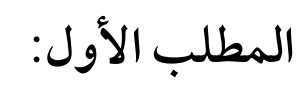 \\
\hline أن يكون الحديث الموقوف خفيًا & 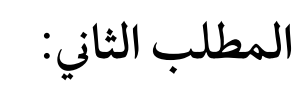 \\
\hline أنواع الموقوفات عند البخاري من حيث الاتصال والتعليق & 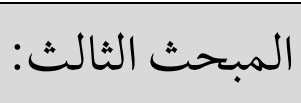 \\
\hline ما رواه البخاري موقوفًا مسندًا & المطلب الأول: المل \\
\hline ما رواه البخاري موقوفًا معلقًا & 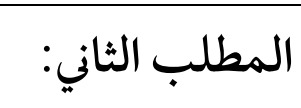 \\
\hline ما رواه البخاري بصيغة قال لنا & 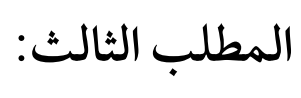 \\
\hline منهج البخاري في سياقة الموقوفات & 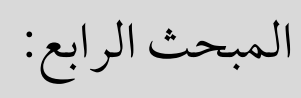 \\
\hline واحد البخاري لأكثر من حديث موقوف والمتن والإسناد & 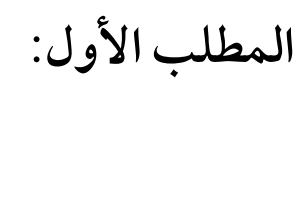 \\
\hline متفرقة بأسانيد مختلفة البخاري للموقوفات عن الصحابي الواحد وهي أحاديث & المطلب الثاني: \\
\hline 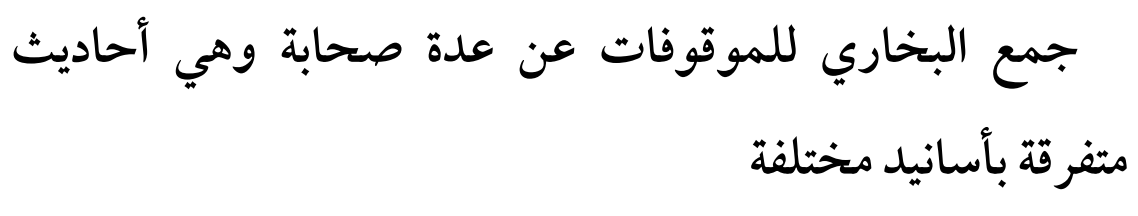 & 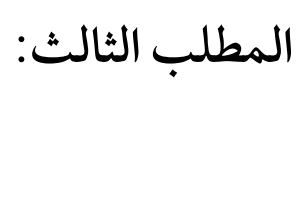 \\
\hline العلاقة بين الحديث الموقوف و ترجمة الباب والحديث & 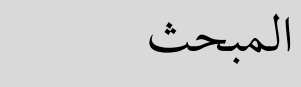 \\
\hline
\end{tabular}




\begin{tabular}{|c|c|}
\hline المرفوع في الباب عند البخاري & 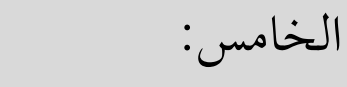 \\
\hline العلاقة بين الحديث الموقوف وترجمة الباب & 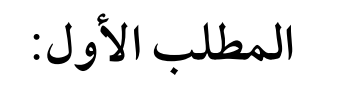 \\
\hline العلاقة بين الحديث الموقوف والحديث المرفوع في الباب & المطلب الثاني: الثب \\
\hline منهج البخاري في ذكر الموقوفات للاستدلال الفقهي & المبحث \\
\hline أهم ما توصلت إليه الدراسة من نتائج & الخاتمة والنتائج \\
\hline بحيح البخاري في كل كتاب & 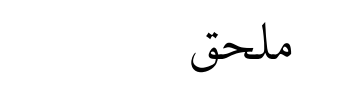 \\
\hline
\end{tabular}




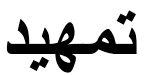 \\ الحديث الموقوف ( تعريفه، وأهميته ) \\ أولاً: تعريف الحديث الموقوف لغة واصطلاحًا ( ) تعريف الموقوف لغة:}

عند الرجوع إلى كتب اللغة وجدنا أن أهل اللغة يطلقون الوقف على معنى الحبس، والسوار، وخِخَاَف الجُلوس.

قال الفراهيدي: وقف: الوَقْفُ: مصدر قولك: وَقَفْتُ الدابة ... والوَقْفْ: المسك الذي يجعل للأيدي، عاجـَ كان أو قرنَّا مثل السوار(1). وقال ابن دريد: والوَقْف: كل

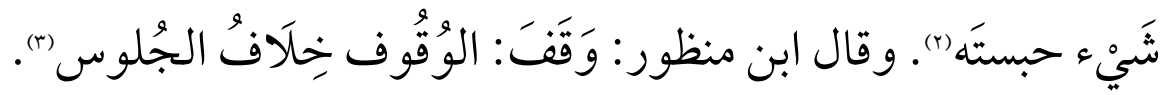

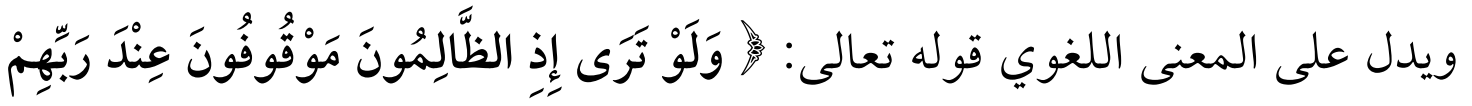

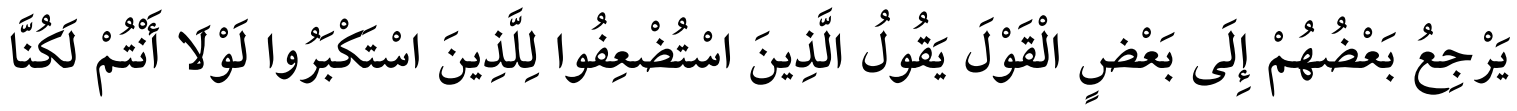
مُؤْمِنِينَ فكأنّ المحدثين أخذوا هذا المعنى اللغوي وأطلقوه على رواية الصحابي وأفعاله فهو

(1) الخليل بن أحمد الفراهيدي، "كتاب العين". تحقيق د. مهدي المخزومي، د. إبراهيم السامرائي. (دار ومكتبة

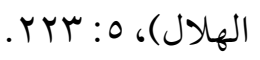

(Y) محمد بن الحسن بن دريد، "جمهرة اللغة". المحقق: رمزي منير بعلبكي. (ط ا، بيروت: دار العلم للملايين، $.97 V: r ،(\rho) 91 \mathrm{~V}$

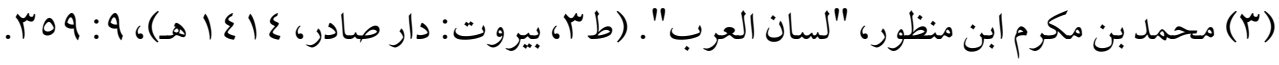

(ع) محمد بن أحمد القرطبي، "الجامع لأحكام القرآن". تحقيق: أحمد البردوني وإبراهيم أطفيش. (طب،

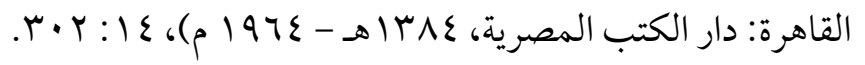




$$
\text { محبوس عنده لا يتعداه إلى غيره كالسوار (1). }
$$

r) تعريف الحديث الموقوف اصطلاحًا: وهو ما يروى عن الصحابة رضي الله عنهم من أقوالهم أو أفعالهم ونحوها، فيوقف عليهم، ولا يتجاوز به إلى رسول الله صلى الله عليه وسلم (r)

\section{ثانيًا: أهمية معرفة الموقوف}

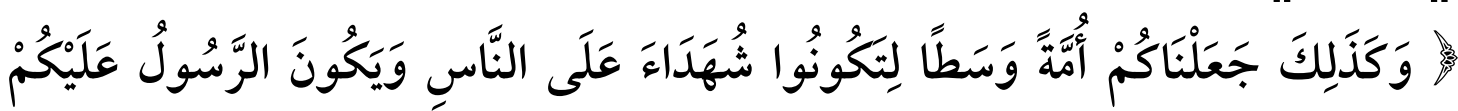

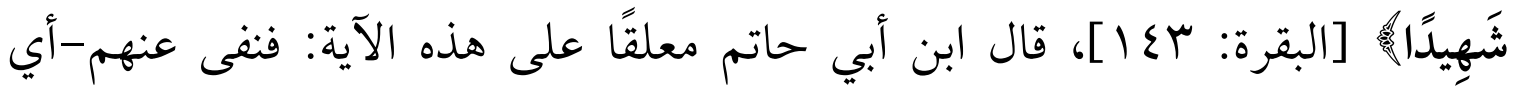
الصحابة- الشك والكذب والغلط والريبة والغمز، وسماهم عدول الأمة، ففسر النبي صلى الله عليه وسلم عن الله عز ذكره قوله (وسطا) قال: عدلا. فكانوا عدول الأمة، وأئمة الهدى، وحجج الدين، ونقلة الكتاب و السنة).(r).

(1) لم أجد في كتب المصطلح من تكلم عن الموقوف من الناحية اللغوية، وقد ذكرها من المعاصرين الدكتور

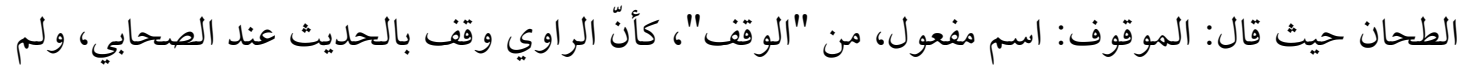

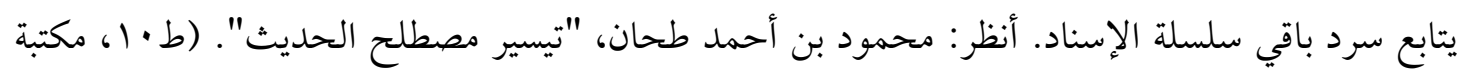

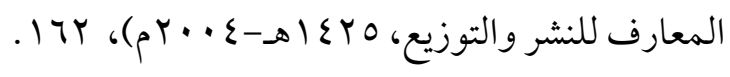

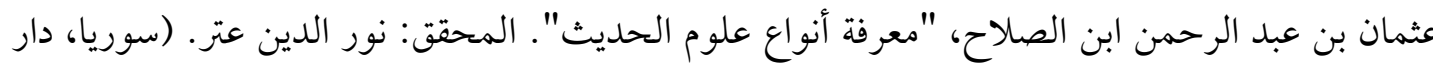

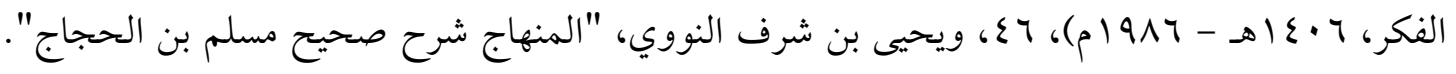

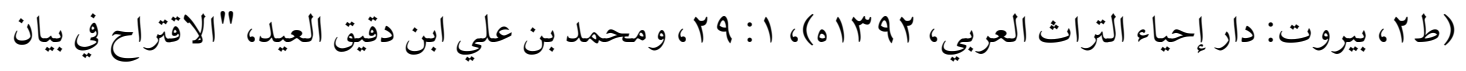

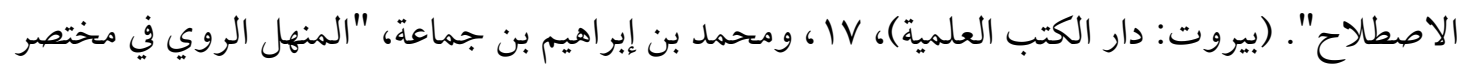

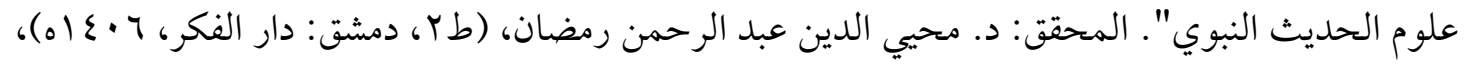

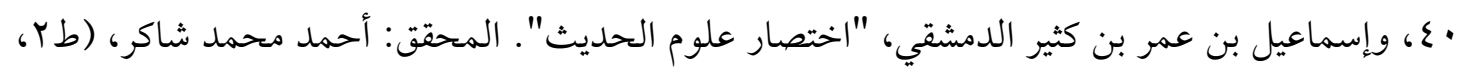

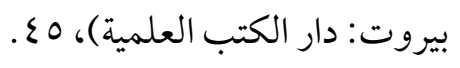

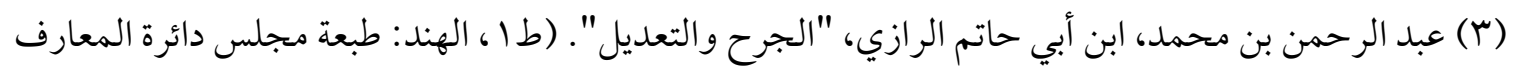

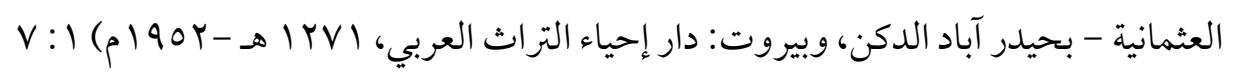




\section{وتأتي أهمية معرفة الموقوف بأمور من أهمها:}

( ) الصحابة رضو ان الله عليهم هم أفضل الأمة لأن الله أختارهم لصحبة النبي صلى الله

عليه وسلم قد أقامو الدين واتبعوه وقد حسنو ا مقصدهم ونياتهم ببر القلوب.

قال عبد الله بن مسعود: (امن كان مستنا فليستن بمن قد مات، أولئك أصحاب محمد

صلى الله عليه وسلم كانوا أفضل الأمة، أبرها قلوبا، وأعمقها علما، وأقلها تكلفا، قوما اختارهم الله لصحبة نبيه صلى الله عليه وسلم، وإقامة دينه، فاعرفوا لهم فضلهم، واتبعوهم في أثرهم، وتمسكوا بما استطعتم من أخلاقهم، ودينهم، فإنهم كانوا على له

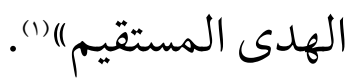

قال ابن تيمية -رحمه الله- معلقًا على قول عبد الله بن مسعود السابق (اكلام جامع، بين فيه حسن قصدهم ونياتهم ببر القلوب، وبين فيه كمال المعرفة ودقتها بعمق العلم، وبين فيه تيسر ذلك عليهم وامتناعهم من القول بلا علم بقلة التكلف)|(r). Y) أهمية كلامهم وفقهاهم فإن الصحابة شاهدوا الوحي والتنزيل، وعرفوا مراد رسول الله صلى الله عليه وسلم، وما أروع كلام الشافعي رحمه الله في أهمية أقوال الصحابة في معرض حديثه عن فضائل الصحابة رضوان الله عنهم أجمعين فقال: "هم أدَّوا إلينا سنن رسول الله، صلى الله عليه وسلم، وشاهدوه و الوحي يُنزل عليه، فعلموا ما أراد رسول الله، صلى الله عليه وسلم، عامَّا وخاصَّا، وعَزْمَّا وإرشاداً،

(1) أحمد بن علي بن ثابت الخطيب البغدادي، "تلخيص المتشابه في الرسم". تحقيق: سُكينة الشهابي، (طا ،

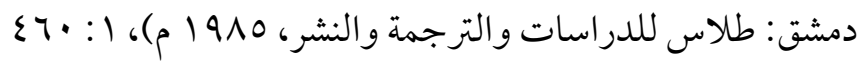

(Y) أحمد بن عبد الحليم بن عبد السلام ابن تيمية، "منهاج السنة النبوية في نقض كلام الشيعة القدرية". المحقق:

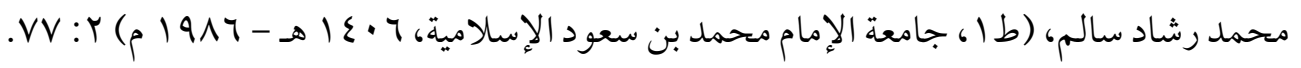


وعرفوا من سنته ما عرفنا وجهلنا، وهم فوقنا في كل علم واجتهاد، وورع وعقل، وأمرٍ استدرك به علم واستنبط به. وآراؤهم لنا أَحْمَدُ وأولى بنا من آرائنا عندنا لأنفسنا" (1) ( )

ץ) وأمر آخر في أهمية معرفة الموقوف وعلاقته بالمرفوع: فإن بعض الروايات المرفوعة تأتي من أوجه موقوفة فيقع الإشكال بتعارض الرفع والوقف فيصعب التمييز بين الموقوف والمرفوع، وهذا له أهمية في كتب المسانيد قال الزركشي: ومعرفة هذا النوع-أي الموقوف والمرفوع- مهمة فمن أراد أن يخرج مسانيد الصحابة فإنه يحتاج إلى معرفة المتون المرفوعة والموقوفة فإن منها ما يُشكل (r).

(1) أبو بكر أحمد بن الحسين البيهقي (101 هـ)، "مناقب الشافعي". المحقق: السيد أحمد صقر. (ط ا، القاهرة:

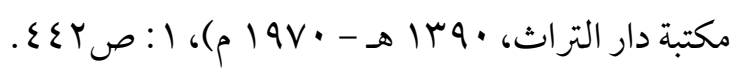




\section{المبحمث الأول \\ المقاصد العامة لذكر البخاري للحديث الموقوف الأن}

من المقاصد التي من أجلها أورد البخاري الموقوفات في صحيحه:

أولاًا: أن يفرق البخاري بين الموقوف وبين ما كان على شرطه في أصل كتابه').

إن المقصود من تصنيف البخاري لكتابه الصحيح هو الأحاديث الصحيحة المسندة

الذي يشعر به اسمه الذي سماه به وهو الجامع المسند الصحيح). قال ابن حجر:

فالمقصود من هذا التصنيف بالذات هو الأحاديث الصحيحة المسندة وهي التي ترجم لها والمذكور بالعرض والتبع الآثار الموقوفة والأحاديث المعلقة والآيات المكرمة فجميع ذلك مترجم به (r).

ثانيًا: أن يضيق على البخاري في ترجمة الباب حديثًا مرفوعًا على شرطه أو حديثًا مرفوعًا معلقًا على غير شرطه:

إنّ البخاري عندما يترجم للباب يذكر الحديث المرفوع في الباب الذي على شرطه، فإذا لم يجد على شرطه علق حديثًا مرفوعًا على غير شرطه، فإن لم يجد ذكر آثار الصحابة)

(1) ابن الملقن عمر بن علي، "المقنع في علوم الحديث". المحقق: عبد الله بن يوسف الجديع. (ط ا ، السعودية:

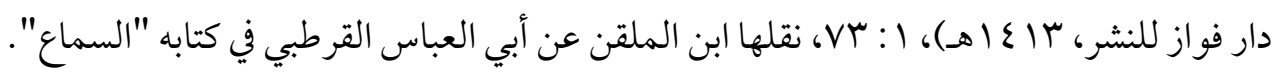

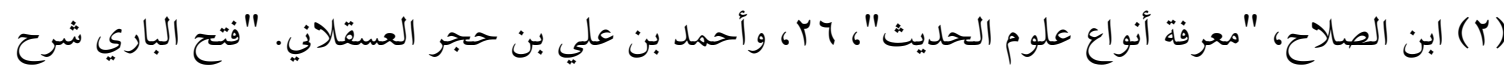

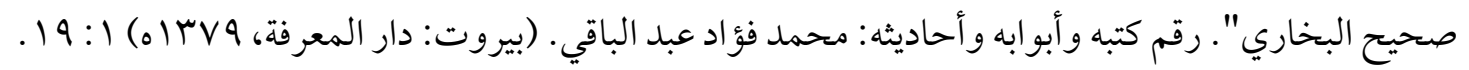

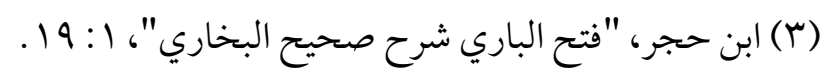

(ع) عبد الرحمن بن أحمد بن رجب الحنبلي، "فتح الباري شرح صحيح البخاري". تحقيق: محمود بن شعبان

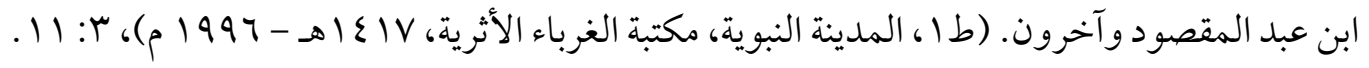


قال ابن رجب في الرد على الحاكم في إخراجه حديثًا قال عنه الحاكم على شرط

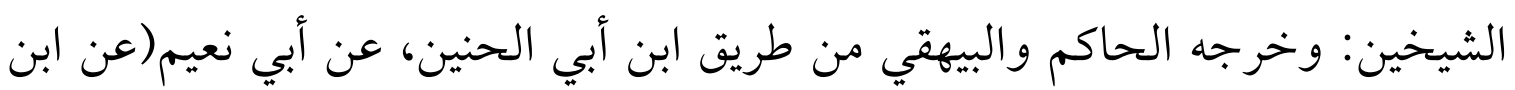

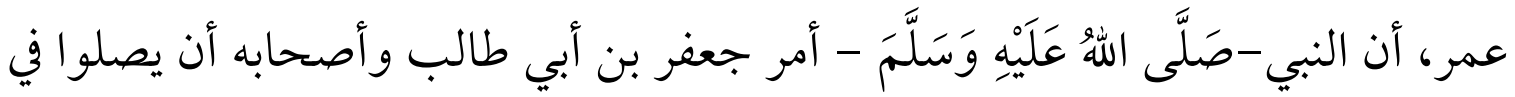

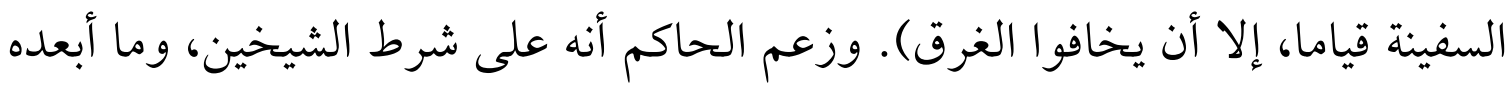
من ذلك، ولو كان مقاربا لشرط البخاري فضلا عن أن يكون على شرطه لذكره تعليقا، ولم يقتصر على ما روى عن الصحابة خاصة"). ولعل هذا المنهج الذي سلكه البخاري تأثر فيه ممن سبقه من مذاهب القدماء من مشهوري الفقهاء. - مشاء قال الخطيب: إن مذاهب القدماء من مشهوري الفقهاء لا يورد من ذلك-أي الأحاديث المسندات- إلا ما ثبتت عدالة رجاله واستقامت أحوال رواته فإن لم يصح في الباب حديث مسند اقتصر على إير اد الموقوف و المرسل (r). ثالثًا: يورد الموقوفات على طريق الاستئناس والتقوية لما يختاره من المذاهب في المسائل التي فيها الخلاف بين الأئمة'). رابعًا: جمع النصوص الشرعية من آيات وأحاديث مرفوعة وأحاديث موقوفة ليفسر بعضها بعضًا. قال ابن حجر: إن الآثار الموقوفة والأحاديث المعلقة والآيات المكرمة المترجم بها

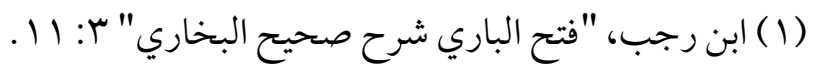

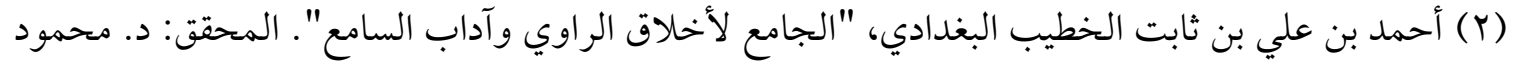

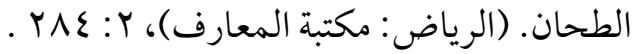

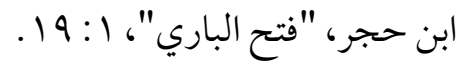


إذا اعتبرت بعضها مع بعض واعتبرت أيضا بالنسبة إلى الحديث يكون بعضها مع بعض منها مفسر ومنها مفسر فيكون بعضها كالمترجم له باعتبار ولكن المقصود بالذات هو الأصل (1)

خامسًا: الإشارة إلى تعارض الوصل والإرسال وترجيح أحدهما: فإذا تعارض الوصل والإرسال في المرفوع عند البخاري أخرج الموقوف لهذه العلة

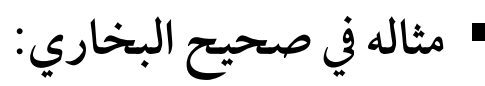

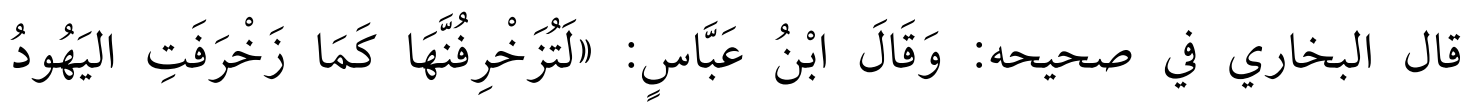
وَالنَّصَارَى")(1). قال ابن حجر: وكلام ابن عباس فيه مفصول من كلام النبي صلى الله عليه وسلم في الكتب المشهورة وغيرها، وإنما لم يذكر البخاري المرفوع منه للاختلاف على يزيد بن سين

$$
\text { الأصم في وصله وإرسالدها.". }
$$

قال العيني: هذا التعليق رواه أبو داود موصولا عن ابن عباس هكذا موقوفا، وروي عنه مرفوعا، قال: حدثنا محمد بن الصباح عن سفيان أخبرنا سفيان بن عيينة عن سفيان الثوري عن أبي فزارة عن يزيد بن الأصم عن ابن عباس، قال: قال رسول صلى الله عليه

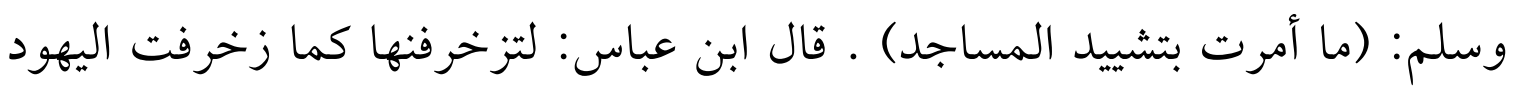
والنصارى، وأبو فزارة اسمه راشد ابن كيسان، وإنما اقتصر البخاري على الموقوف منه

$$
\begin{aligned}
& \text { (1) (1) المرجع السابق. }
\end{aligned}
$$

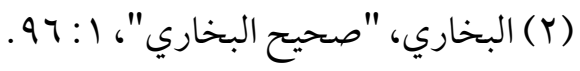

$$
\begin{aligned}
& \text { (r) ابن حجر، "فتح الباري"، إ: • } 0 .
\end{aligned}
$$




\section{ولم يذكر المرفوع منه للاختلاف على يزيد بن الأصم في وصله وإرساله"(1). سادسًا: الإشارة إلى أن الحديث المرفوع معلول وضعيف:}

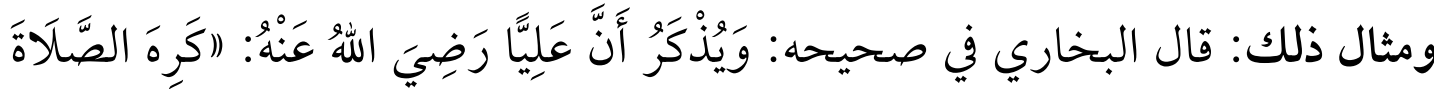

$$
\text { بحخَسْفِ بَابَلَ)(1) }
$$

قال ابن حجر: هذا الأثر رواه بن أبي شيبة من طريق عبد الله بن أبي المُحِلّ قال: كنا مع علي فمررنا على الخسف الذي ببابل فلم يصل حتى أجازه أي تعداه ومن طريق أخرى عن علي قال: ما كنت لأصلي في أرض خسف الله بها ثلاث مرار... ورواه أبو داود مرفوعا من وجه آخر عن علي ولفظه نهاني حبيبي صلى الله عليه وسلم أن أصلي في أرض بابل فإنها ملعونة في إسناده ضعف واللائق بتعليق المصنف ما تقدم"(r). ومثال آخر: قال البخاري في صحيحه: وَيْذْكَرُ عَنْ بِلَلٍ: (أَنَّهُ جَعَلَ إِصْبَعَيْهِ فِي

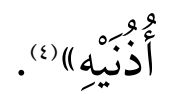

وحديث بلال قد روي موقفًا ومرفوعًا: فالموقوف صحيح لذلك أخرجه البخاري(م)، والحديث المرفوع: فقد بين الحافظ ابن رجب أنها روايات معلولة وقال: ولهذا لم

$$
\begin{aligned}
& \text { (1) العيني، "عمدة القاري"، ؟: 0.r. }
\end{aligned}
$$

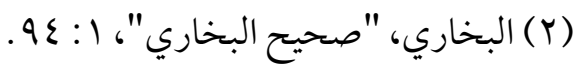

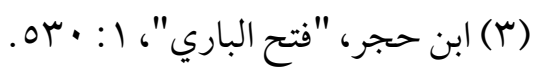

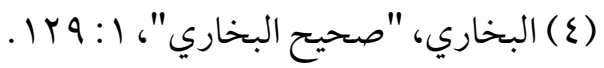

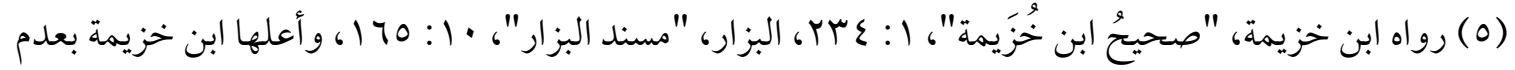
سماع الحجاج من عون بن أبي جحيفة، ورد ابن حجر: بأنه صرح بالسماع عند سعيد بن منصور في السنن،

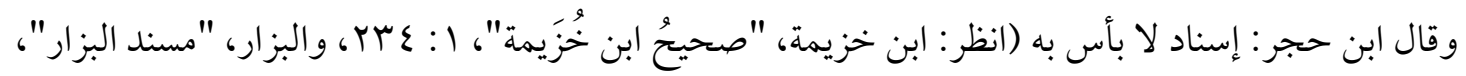

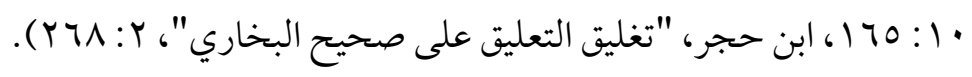


يخرجها البخاري مسندة، ولم يخرجها مسلم - أيضا، وعلقها البخاري بصيغة التمريض، وهذا من دقة نظره ومبالغته في البحث عن العلل والتنقيب عنها - رضي الله عنه"(). وبين الحافظ ابن حجر أن في هذا الحديث زيادتان إحداهما الاستدارة والأخرى

$$
\text { وضع الإصبع في الأذن وهي مدرجة(r). }
$$

\section{سابعًا: الإشارة إلى تعارض الوقف والرفع وترجيح الوقف:}

ومثال ذلك: قال البخاري في صحيحه: وَقَالَ نَافِعْ: اركَانَ ابْنُ عُمَرَ يَضَعُ يَدَيْهِ قَبْلَ

$$
\text { (r) (I) }
$$

قال ابن رجبَ(): وأما ما ذكره البخاري، عن نافع -تعليقـًا -، قال: كان ابن عمر يضع يديه قبل ركبتيه. فخَّرج ابن خزيمة في ((صحيحه)) (م)، و الدارقطني (1) من رواية أصبغ بن الفرج، عن الدراوردي، عن عبيد الله بن عمر، عن نافع، عن ابن عمر، إنه كان يضع يديه

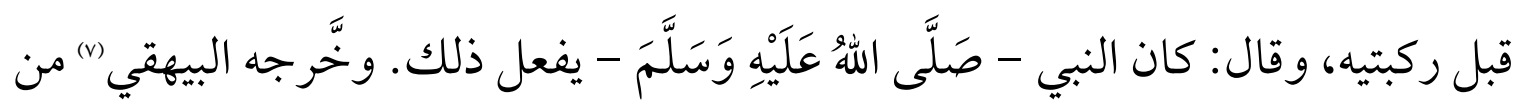

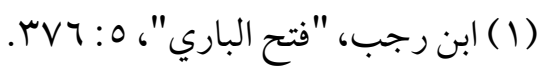

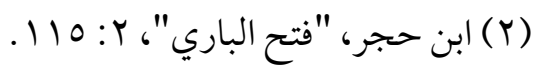

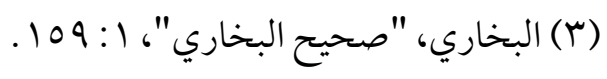

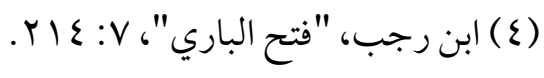

(0) محمد بن إسحاق ابن خزيمة، "صحيحُ ابن خُزَيمة". حَققعُ وعَلِّق عَلَيه وَخَرَّجَ أحَاديثه وَقَدَّم له: الدكتور

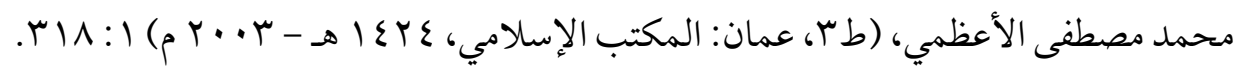

علي بن عمر الدارقطني، "سنن الدارقطني". حققه وضبط نصه وعلق عليه: شعيب الارنؤوط، وأخرون

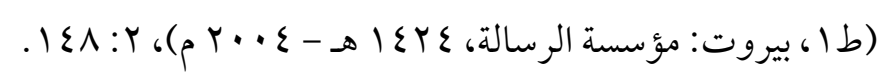

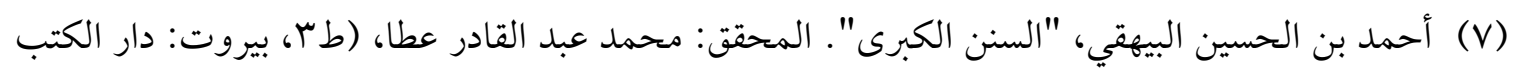

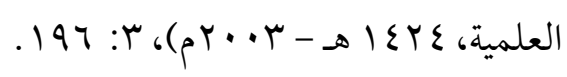


رواية محرز بن سلمة، عن الدراوردي، به. وقال البيهقي (1): ما أراه إلا وهمكا - يعني:

رفعه.

وقد رواه ابن أخي ابن وهب، عن عمه، عن الدراوردي كذلك. وقيل : أن أشهب رواه

عن الدراوردي كذلك. ورواه أبو نعيم الحلبي، عن الدراوردي، فوقفه على ابن عمر، قال الدارقطني (r): وهو الصواب.

ثامنًا: تأكيد الحديث الموقوف للحديث المرفوع:

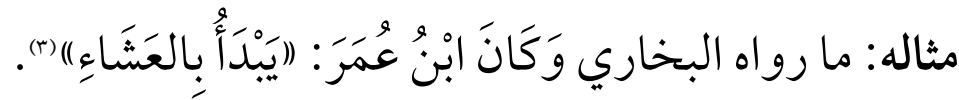

قال العيني: هذا الأثر مذكور في الباب بمعناه مسندا قريبا حيث قال البخاري: حَدَّثنَّا

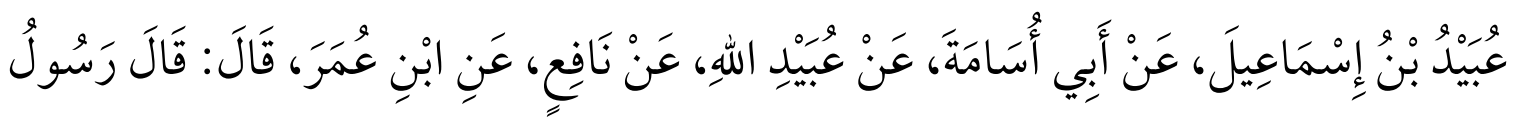

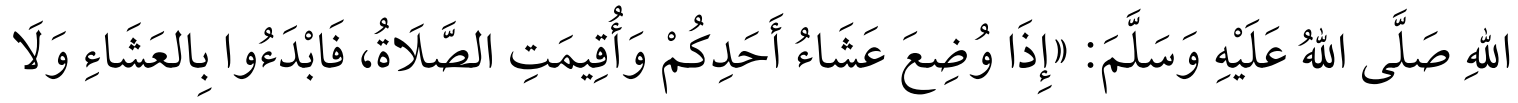

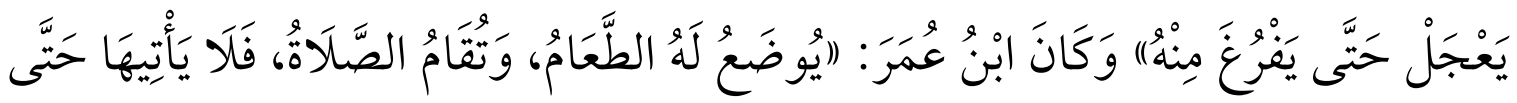

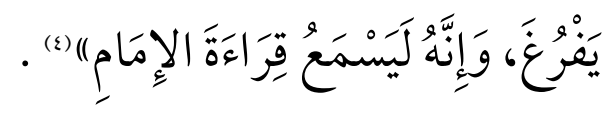

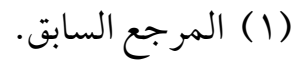

(Y) لم أجد هذا القول للدارقطني في السنن، وقد روى هذا الحديث في "الإفر اد" ب: rاع، ولم يذكر هذا القول أيضًا، ولعل ابن رجب اطلع على نسخة أخرى غير الذي بين أيدينا.

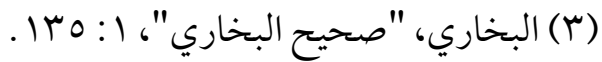

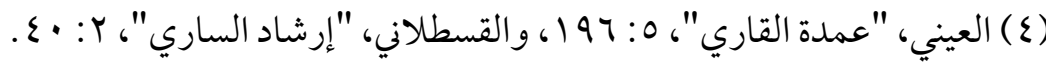




\section{المبحث الثماني \\ أنواع الموفوف من حيث الظهور والخفاء ومنهج البخاري فيه يُقسم الحديث الموقوف من حيث ما يميزه عن المرفوع والمقطوع إلى قسمين: \\ - - أن يكون الموقوف جليا يظهر لكل أحد'). r - r أن يكون الموقوف خفيا"(}

وبيان هذا التقسيم في صحيح البخاري هو كالتالي: المطلب الأولٍ هول

أن يكون الحديث الموقوف جلينًا:

وهو ما لا يحتاج إلى مزيد نظر لتمييزه عن المرفوع وعن المقطوع، ومن أمثلة ذلك ما

$$
\text { ورد في صحيح البخاري: }
$$

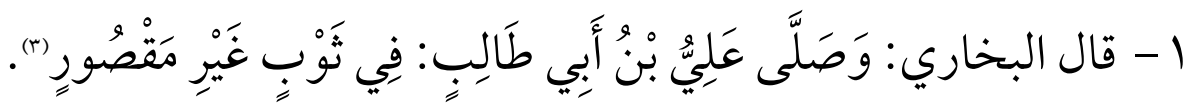

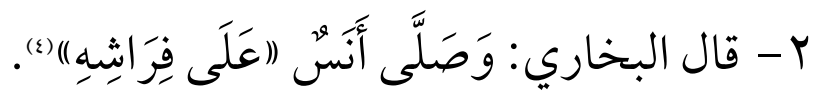

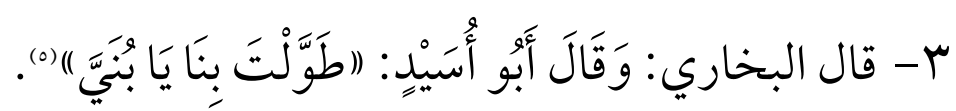

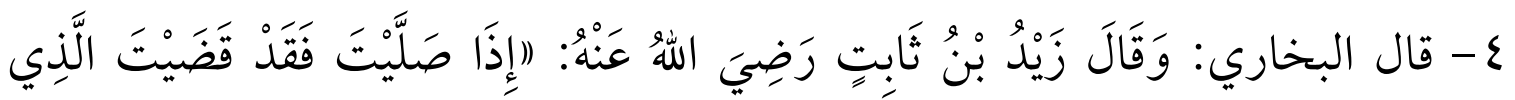
(1) (1) عَلَيْكَ

(1) محمد بن عبد الله الزركشي، "النكت على مقدمة ابن الصلاح". المحقق: د. زين العابدين بن محمد بلا

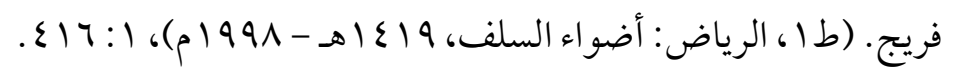

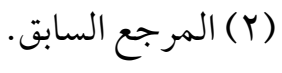

(r) البخاري، "صحيح البخاري"، كتاب الصلاة، باب الصلاة في الجبة الشامية، I: 11.

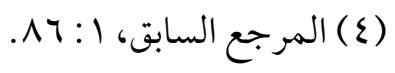

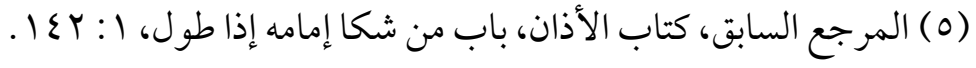

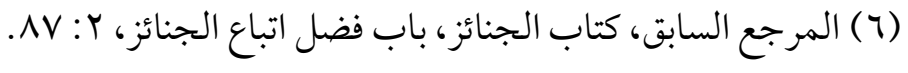




\section{المطلب الثاني}

\section{أن يكون الحديث الموقوف خفيًا}

وهو ما يحتاج إلى مزيد نظر لتمييزه عن المرفوع وعن المقطوع، فحتى نميزه لا بد من الرجوع إلى الروايات الأخرى، والبحث في القرائن، وإلى كلام العلماء الذين وقفوا على أصول الروايات في المصادر المتنوعة، ومن هذه الصور:

\section{الصورة الأولى: الظاهر أن الحديث موقوف والصحيح أنه مقطوع:}

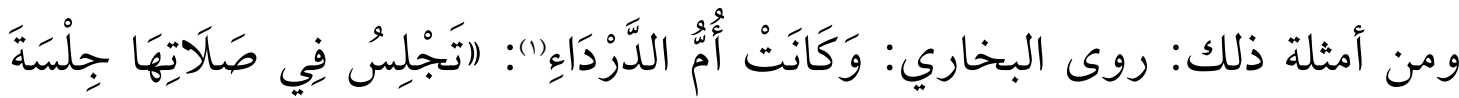

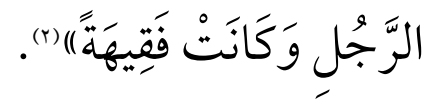

فإن الناظر إلى هذا المروي يظن أن أم الدرداء هي الصحابية فيحكم عليه أنه حديث موقوف، ولكن عند مراجعة هذه الرواية فقد رواها البخاري في التاريخ الأوسط: عَن

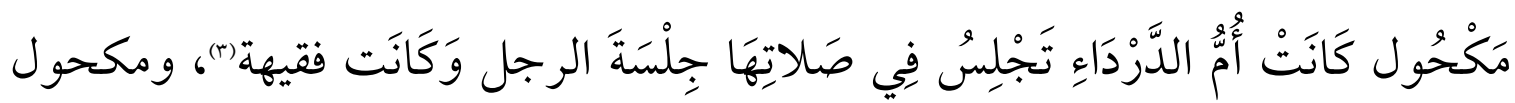
الشامي له رواية عن أم الدرداء الصغرى وليس له رواية عن الكبرى() فتبين أن هذه

(1 ) أم الدرداء الصغرى اسمها هجيمة، وقال بعضهم: جهيمة وهي بنت حبي الأوصابية قبيلة من حمير، و الكبرى:

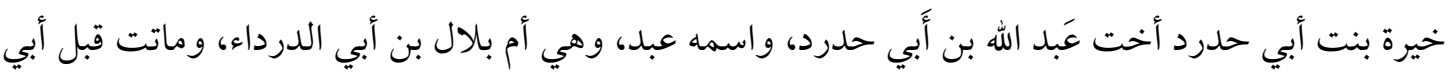
الدرداء، وهما جميعا كانتا تحت أبي الدرداء، وماتت الصغرى بعد سنة إحدى وثمانين، وكانت من العابدات،

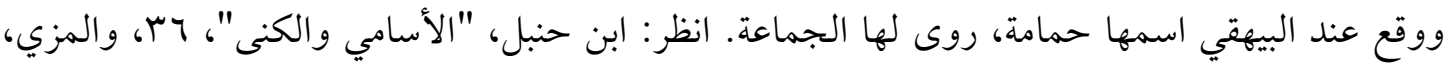

$$
\begin{aligned}
& \text { "تهذيب الكمال في أسماء الرجال"، 0: به r، وابن حجر، "تهذيب التهذيب"، r 1 : 77ع. } \\
& \text { (Y) البخاري، "صحيح البخاري"، كتاب الأذان، باب سنة الجلوس في التشهد، 1: } 170 \text {. }
\end{aligned}
$$

(Y) محمد بن إسماعيل البخاري، "التاريخ الأوسط". المحقق: محمود إبر اهيم زايد. (ط ا، حلب، القاهرة: دار

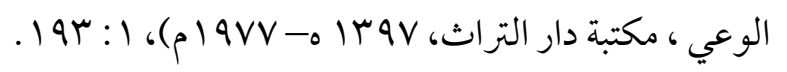

(ع) يوسف بن عبد الرحمن بن يوسف المزي، "تهذيب الكمال في أسماء الرجال". المحقق: د. بشار عواد

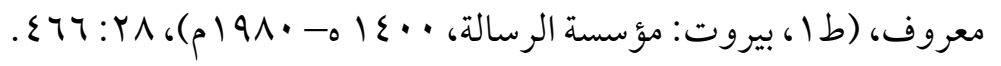


الرواية من روايات التابعين. فقد تميز هذا الأثر المقطوع عن الموقوف بقرينة أن

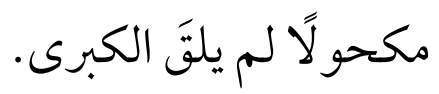

قال ابن حجر: وعرف من رواية مكحول أن المراد بأم الدرداء الصغرى التابعية لا لا

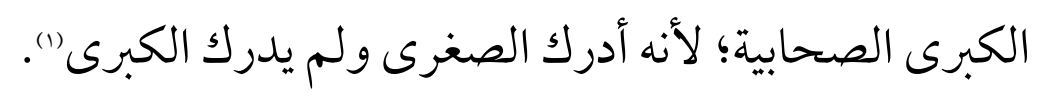

\section{الصورة الثانية: الظاهر أن الحديث موقوف والصحيح أنه مرفوع:}

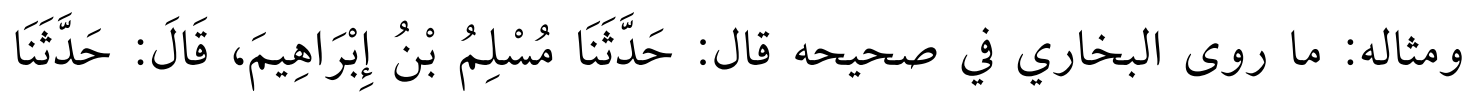

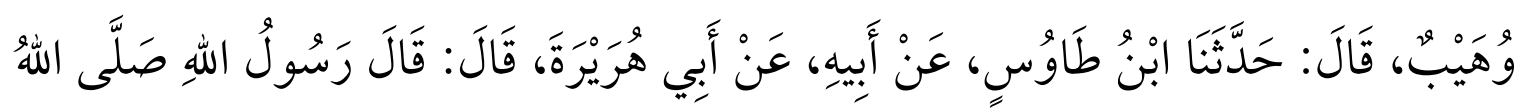

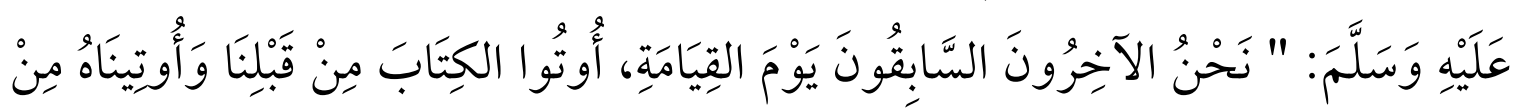

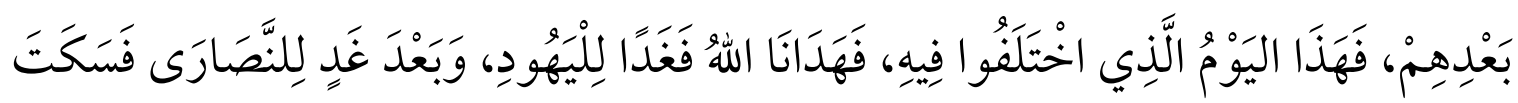

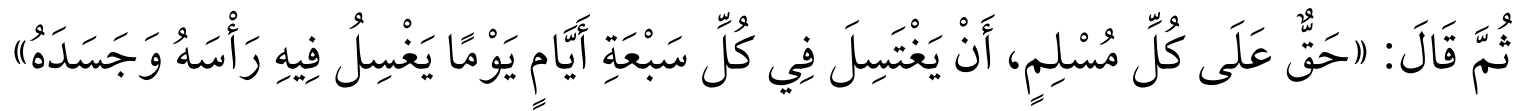

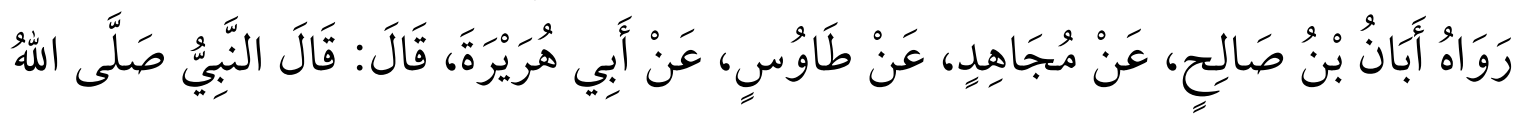

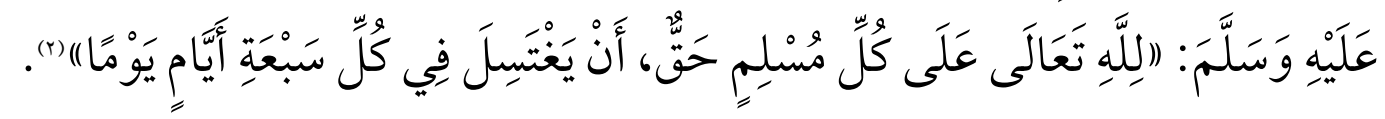
الناظر إلى هذا الحديث عند قوله "فسكت ثم قال" يظن أنه موقوف ولكنه في الحقيقة

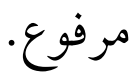
قال ابن رجب("): إنما ذكر رواية أبان بن صالح المعلقة؛ ليبين أن آخر الحديث -

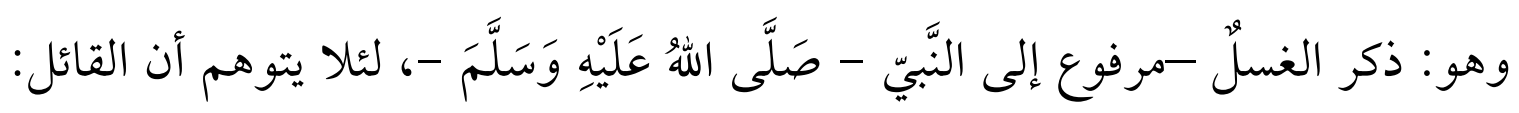

$$
\begin{aligned}
& \text { (1) (1) (بن حجر، ، "فتح الباري"، r: צ.r. }
\end{aligned}
$$

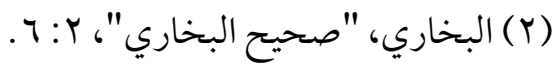

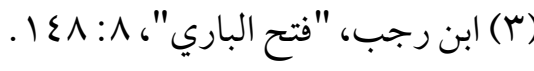


((حقّ على كل مسلمٍ) في آخر حديث وهيبٍ، عن ابن طاوسٍ، عن أبيه -: هو أبو

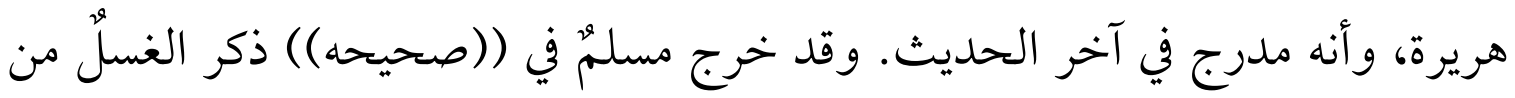

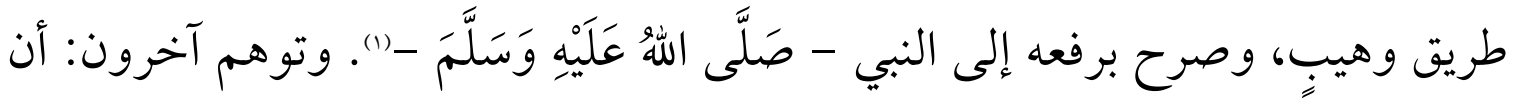

$$
\text { ذكر الغسل في آخر الحديث مدرج من قول أبي هريرة. }
$$

وقال ابن حجر ((): في حديث أبي هريرة فسكت ثم قال حق على كل مسلم إلخ فاعل سكت هو النبي صلى الله عليه وسلم فقد أورده المصنف(") في ذكر بني إسرائيل من وجه آخر عن وهيب بهذا الإسناد دون قوله فسكت ثم قال ويؤكد كونه مرفوعا رواية مجاهد عن طاوس المقتصرة على الحديث الثاني ولهذه النكتة أورده بعده فقال رواه أبان بن

صالح

\section{الصورة الثالثة: الظاهر أن الحديث مرفوع والصحيح أنه موقوف:}

ومقصود ذلك أن نص الكلام يشتبه على القارئ فهو شبيه بكلام النبي صلى الله عليه وسلم ولكن في حقيقة الأمر أنه موقوف من كلام الصحابي.

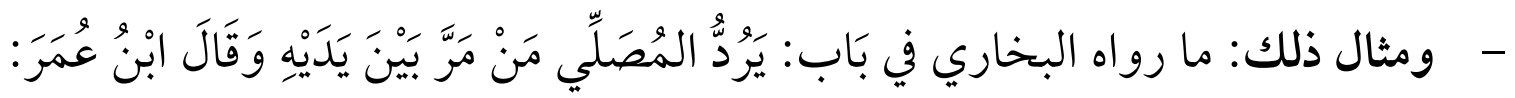

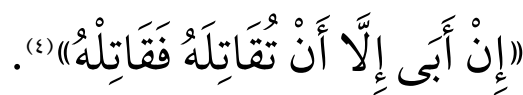

(1) مسلم بن الحجاج، "صحيح مسلم". المحقق: محمد فؤاد عبد الباقي، (القاهرة: دار إحياء الكتب العربية:

$$
\begin{aligned}
& \text { فيصل عيسى البابي الحلبي) Y: r Y Y. }
\end{aligned}
$$

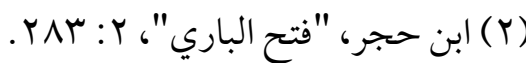

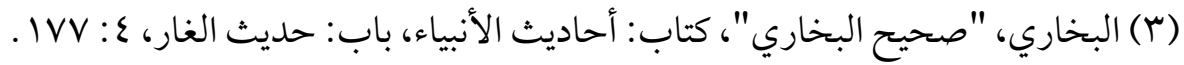

(ع) البخاري، "صحيح البخاري"، ا: v•ا، وعبد الرزاق بن همام الصنعاني، "المصنف". المحقق: حبيب

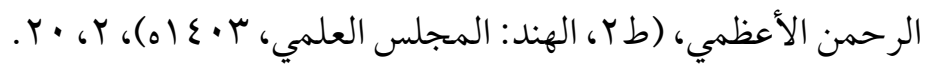


فإن قول ابن عمر يشتبه على القارئ بأنه يشبه كلام النبي صلى الله عليه وسلم فيظن أنه مرفوع، ولكن بيّن ابن حجر أن هذا هو من كلام ابن عمر، قال ابن حجر : هذه الجملة الأخيرة من كلام ابن عمر أيضا، وقد وصلها عبد الرزاق ولفظه عن ابن عمر قال "الَالَََّغْ

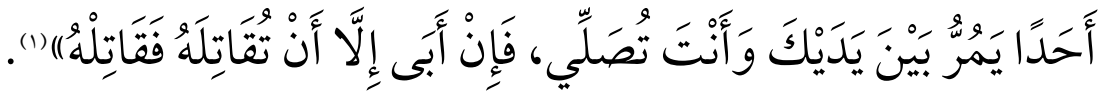

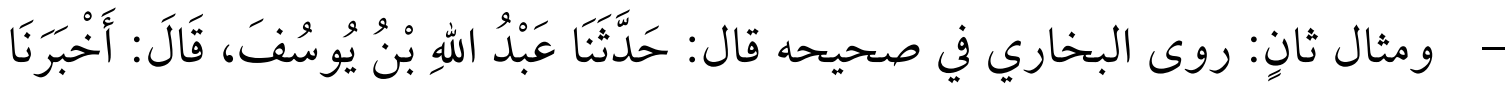

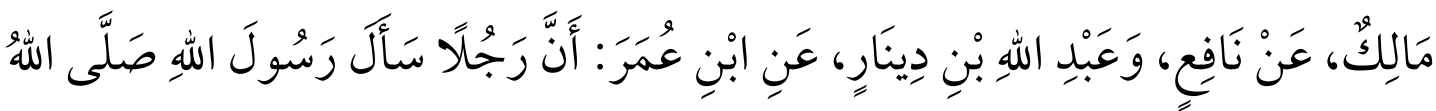

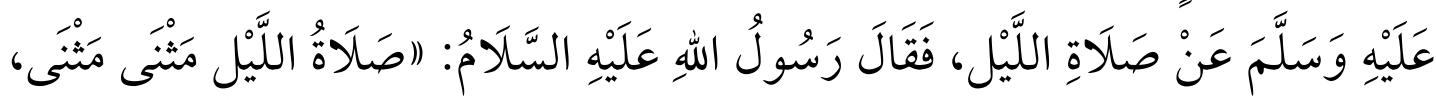

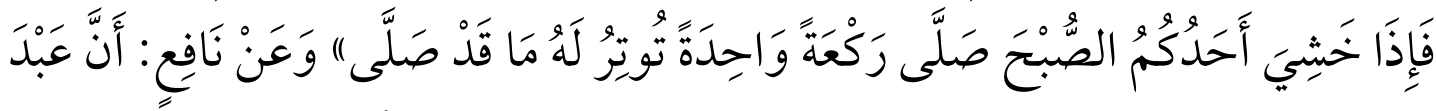

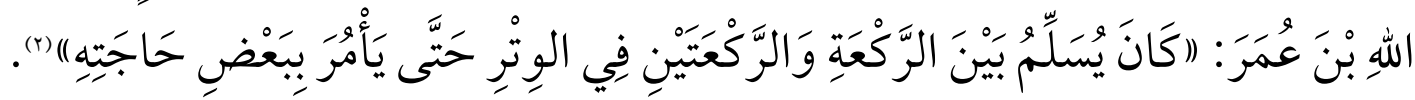
الناظر إلى الحديث الثاني يظن أنه تابع للحديث الأول مرفوع إلى النبي صلى الله عليه وسلم ولكن بيّن العلماء أنه موقوف. قال العيني (r): قال بعضهم: وهو معطوف على الإسناد الأول، وليس كذلك، وإنما هو معلق، ولو كان مسندا لم يفرقه، وإنما فرقه لأمرين: أحدهما: أنه كان سمع كلا منهما مفترقا عن الآخر. و الآخر: أنه أراد الفرق بين الحديث والأثر، وهذا ما رواه مالك عن

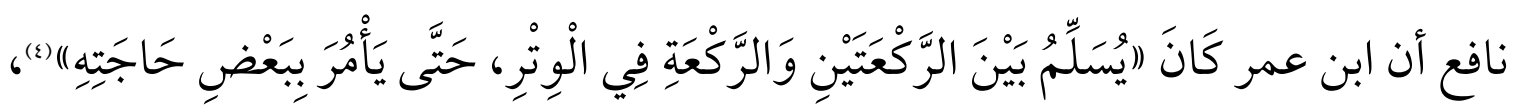

(1) ابن حجر، "فتح الباري"، 1: Y (1)، عبد الرزاق بن همام الصنعاني، المحقق: حبيب الرحمن الأعظمي،

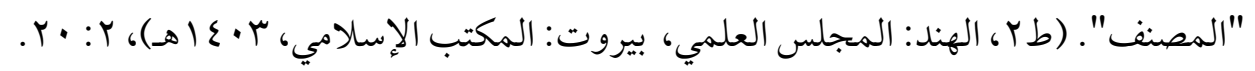

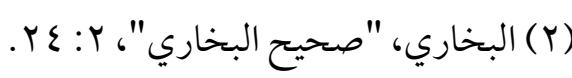

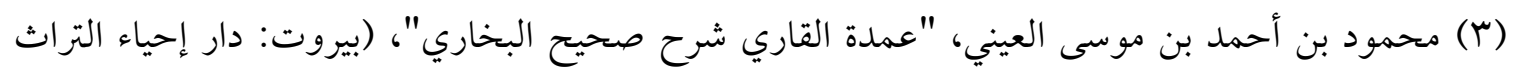

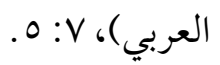
(ع) مالك بن أنس، "الموطأ". صححه ورقمه وخرج أحاديثه وعلق عليه: محمد فؤاد عبد الباقي، (بيروت: دار

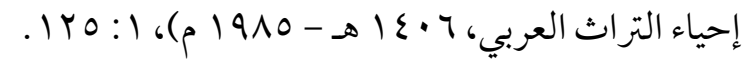


وأخرجه الطحاوي"( أيضا عن يونس بن عبد الأعلى عن أبي وهب عن مالك، وأخرجه

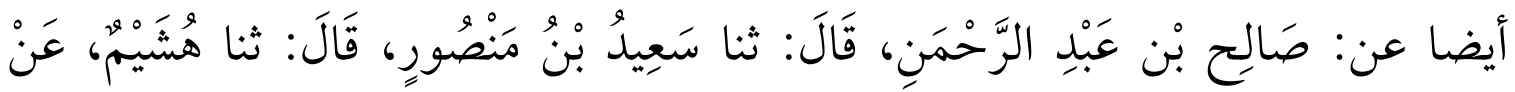

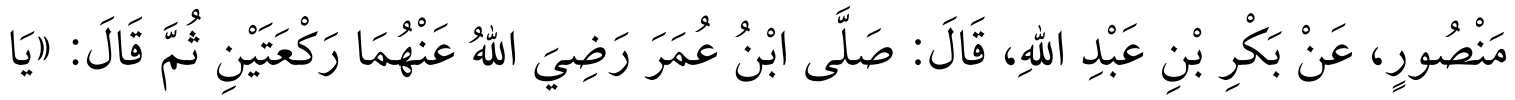

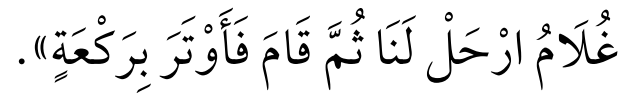
وذكر ابن المنير أنه أثر(م)، وقال ابن حجر عن عن رواية الطحاوي الأولى من طريق مالك

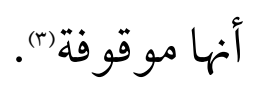

وقد استدرك العلامة محمد بن إسماعيل الأمير -الذي شرح كتاب "تيسير الوصول إلى جامع الأصول" للشيخ العلامة ابن الديبع - على ابن الديبع هذا الحديث وقال: "واعلم أنه في "الموطأ" وجامع ابن الأثير موقوف على ابن عمر، ليس بمرفوع إليه صلى الله عليه وسلم -، و المصنف رفعه إليه - صلى الله عليه وسلم - وهو وهم"(s).

(1) أحمد بن محمد بن سلامة الطحاوي، "شرح معاني الآثار". حققه وقدم له: محمد زهري النجار - محمد سيد

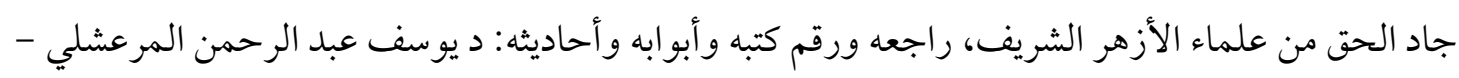

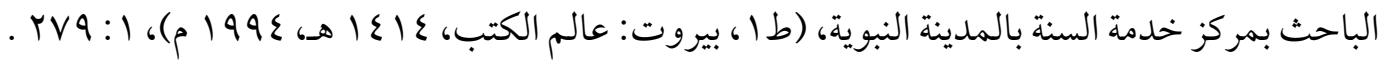
(Y)(Yمر بن علي بن أحمد ابن الملقن، "البدر المنير في تخريج الأحاديث والأثار الواقعة في الشرح الكبير".

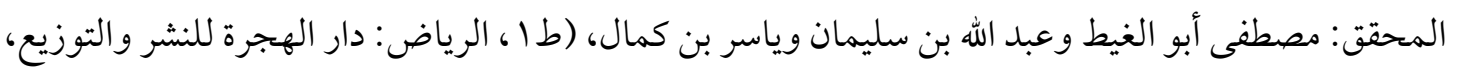

$$
\text { rTะ: }
$$

(r) أحمد بن علي بن حجر العسقلاني، "إتحاف المهرة بالفوائد المبتكرة من أطراف العشرة". تحقيق : مركز خدمة السنة والسيرة ، بإشر اف د. زهير بن ناصر الناصر، راجعه ووحد منهج التعليق والإخراج، (ط ا ، المدينة

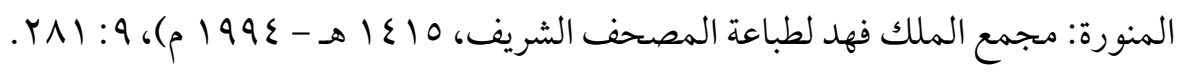

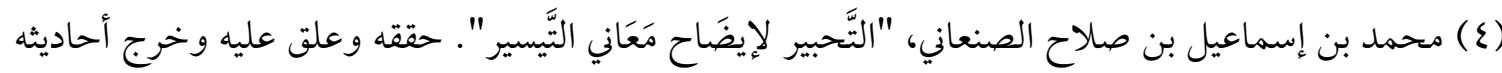

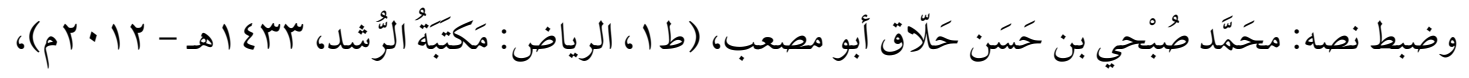


الصورة الرابعة: أن يكون الخفاء مشتر كًا بين الموقوف والمرفوع: مثاله: روى البخاري في بَابِ وَقْت الجُمُعَةِ إِذَا زَالَتِ الشَُّْْْ قال: وَكَذَلِكَ يُرْوَى عَنْ

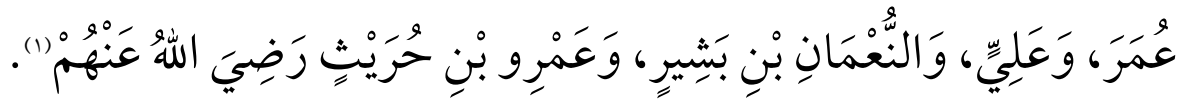
فهل المروي عن هؤلاء الصحابة موقوف أم مرفوع؟ وعند الرجوع إلى كلام العلماء فقد بين ابن رجب والعيني وابن حجر أنها موقوفات على الصحابة، وذكروا من رواها من أصحاب الكتب و المصنفات (r).

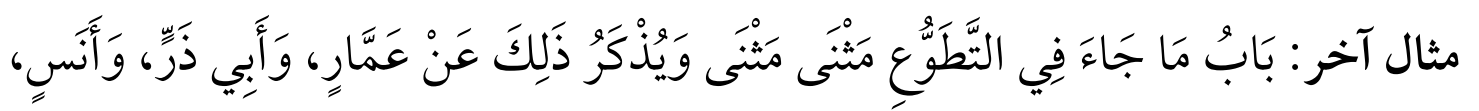

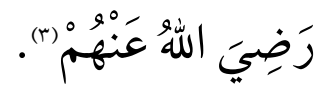

$$
\text { فهل المروي عن هؤلاء الصحابة موقوف أم مرفوع؟ }
$$

وقد ذكر ابن حجر أن رواية عمار ورواية وأبي ذر موقوفان أما رواية أنس فهي مرفوعة، وذكر من رواها من أصحاب الكتب و المصنفات (). ومن خلال ما تم بيانه فهناك بعض القرائن من خلالها يتميز الحديث الموقوف عن

الحديث المرفوع والمقطوع منها: ( ) ( ) تاريخ سماع الرواة Y) مقارنة الروايات بعضها ببعض بعد جمعها.

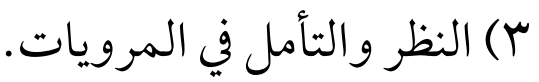

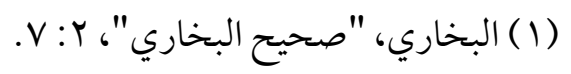

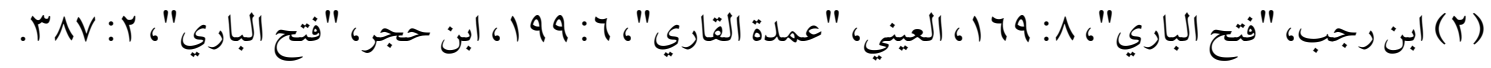

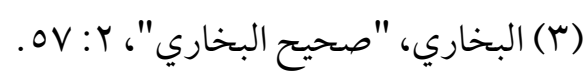

(ع) أحمد بن علي بن حجر العسقلاني، "تغليق التعليق على صحيح البخاري". المحقق: سعيد عبد الرحمن

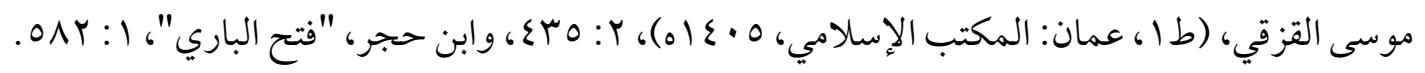




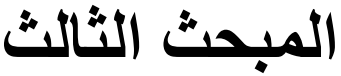

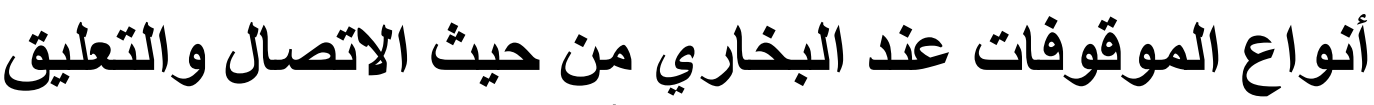
المطلب الأول

\section{ما رواه البخاري موقوفًا مسندًا}

قد يورد البخاري الموقوف أحيانًا متصل الإسناد على خلاف عادته، في إيراده

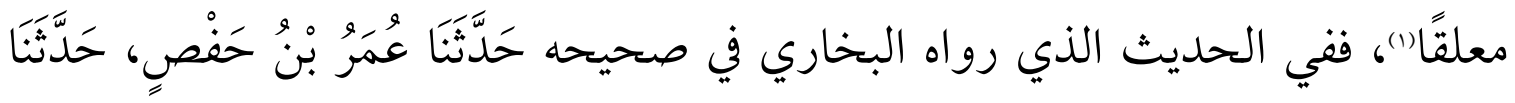

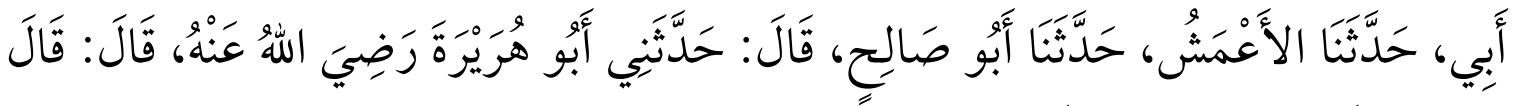

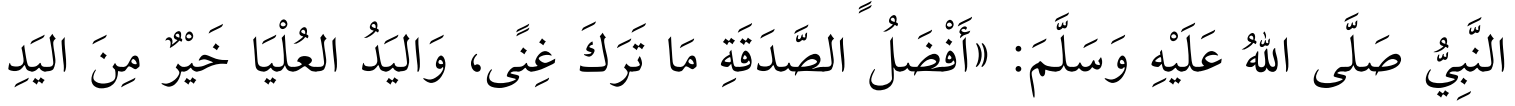

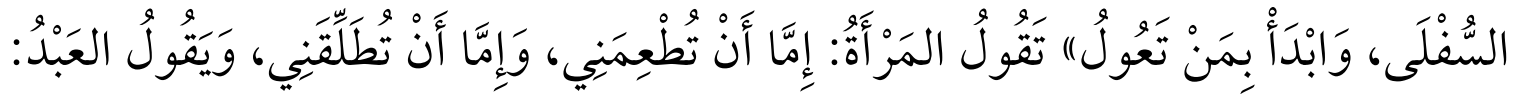

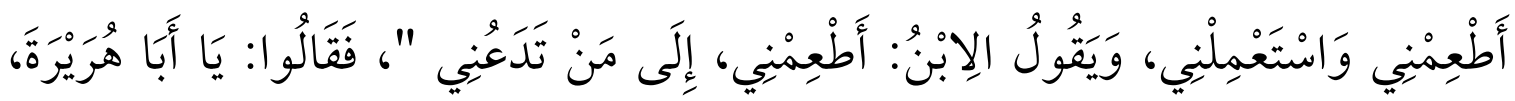

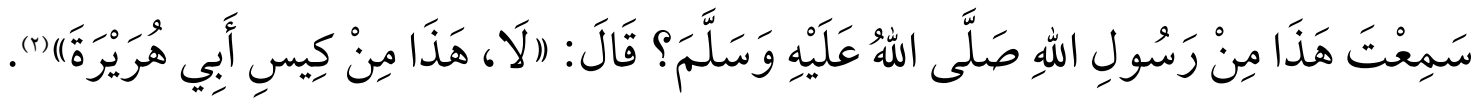
قال ابن حجر فيه: أثر أبي هريرة المتصل بحديث أفضل الصدقة ما ترك عن غنى الحديث، وفيه تقول المرأة إما أن تعطيني وإما أن تطلقني إلخ وبين في آخره أنه من كلام أبي هريرة فهو موقوف متصل الإسناد، وهو من أفراده عن مسلم بخلاف غالب الآثار

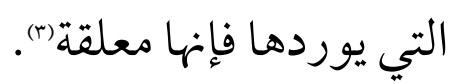
قلنا: إنما ذكره متصلًا لتعلقه بالمرفوع، وقد ذُكر ا بإسناد واحد، ولم يقصد البخاري معاي إسناد الموقوف. ومن أمثلة الموقوف المتصل الإسناد في مجال الدراسة:

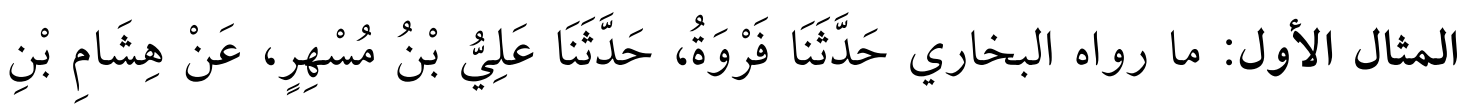

$$
\begin{aligned}
& \text { (1) انظر : ابن حجر، "فتح الباري"، 9 : } 9 \text { IV. }
\end{aligned}
$$

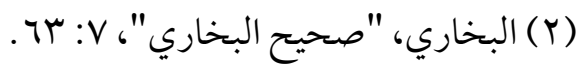

$$
\begin{aligned}
& \text { (r) انظر : ابن حجر، "فتح الباري"، 9 : } 0 \text { IV. }
\end{aligned}
$$




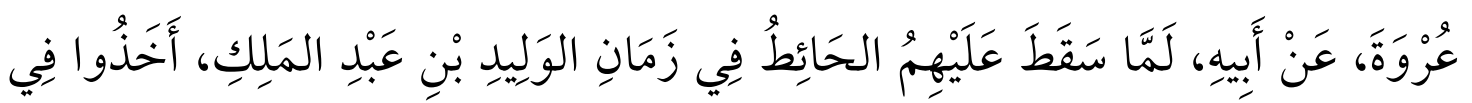

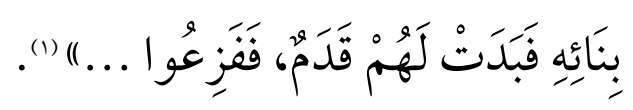

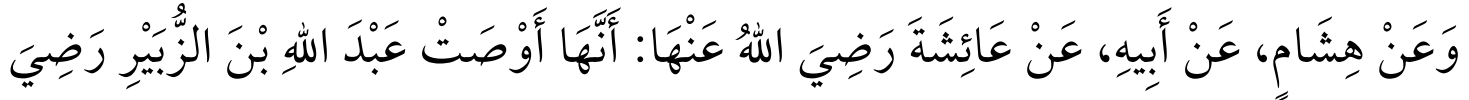

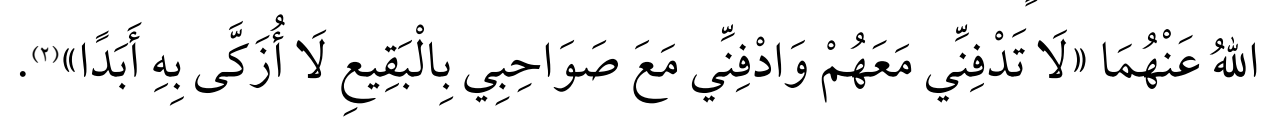

وعن هشام عن أبيه: هو بالإسناد المذكور وقد أخرجه البخاري في الاعتصام من آنسا

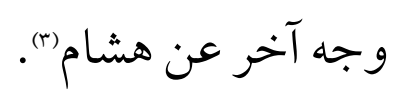

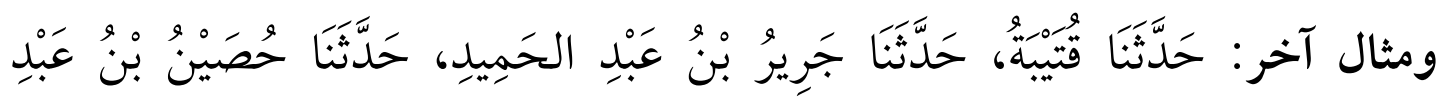

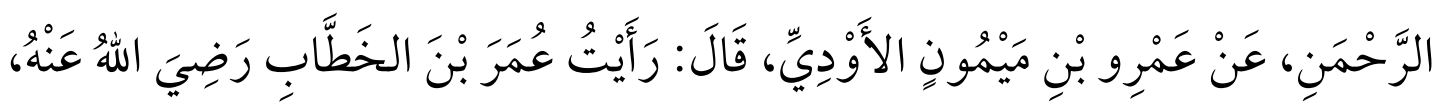

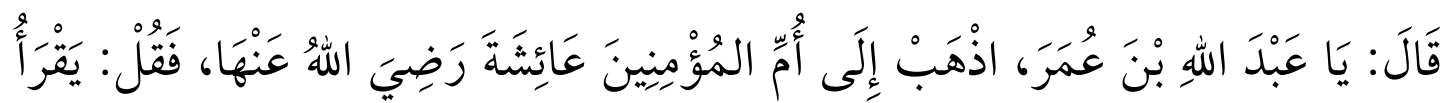

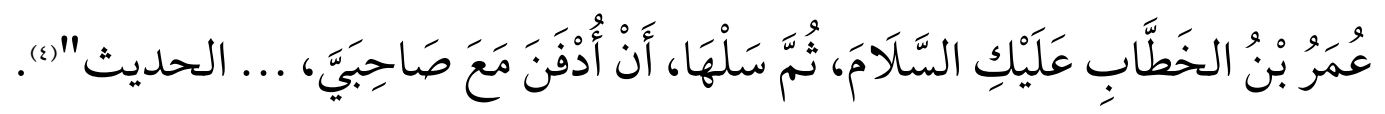

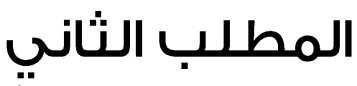 \\ ما رواه البخاري موقوفًا معلقا}

من عادة البخاري أن يورد الموقوفات معلقة(م)، وهو الغالب في كتابه الصحيح ومن مالفا

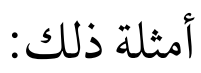

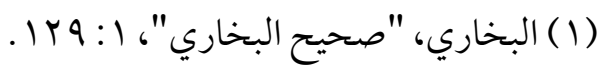

$$
\begin{aligned}
& \text { (Y) المرجع السابق. }
\end{aligned}
$$

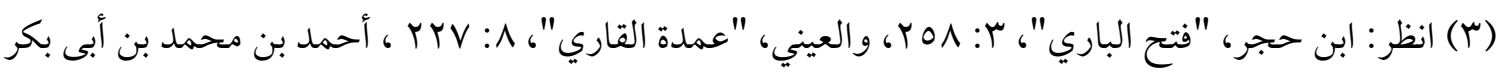

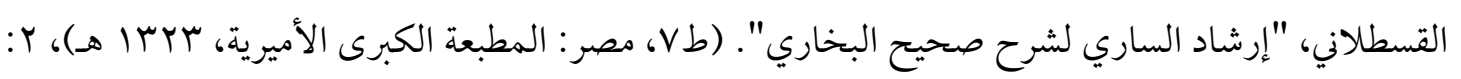

$$
\begin{aligned}
& \text { (0) البخاري، "صحيح البخاري"، ؟: ؟ •1. } \\
& \text { انظر: ابن حجر، "فتح الباري"، } 9 \text { : } 01 \text { ه. }
\end{aligned}
$$




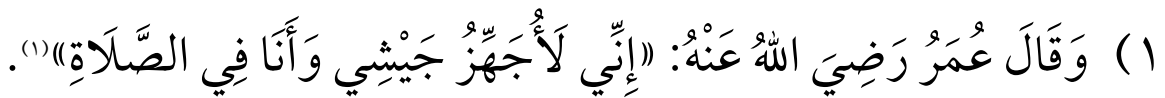

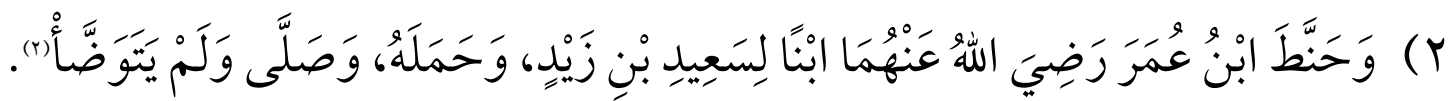

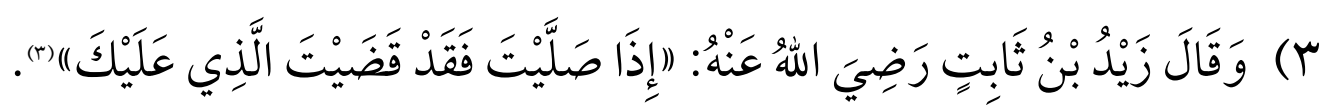

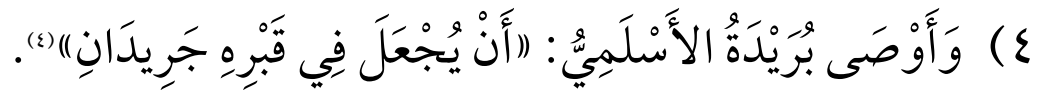

\section{ومن صور التعليق:}

\section{O الصورة الأولى: ما رواه البخاري موقوفًا بصيغة الجزم:}

من إحدى استعمالات البخاري لهذه الصيغة استعمالها في الموقوفات، وقد ذهب كثير من العلماء إلى صحة الحديث الذي جزم به البخاري ومنهم: النووي(ه)، وابن رجب(1)، والشيخ جمال الدين الإسنوي(()، وابن المنير(()، وابن كثير(ه)، وغيرهم. ومن

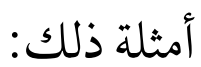

$$
\begin{aligned}
& \text { (1) البخاري، "صحيح البخاري"، ؟: V Y. }
\end{aligned}
$$

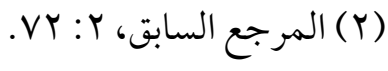

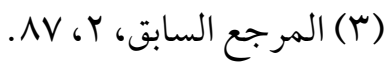

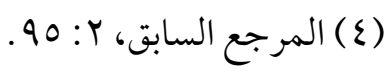

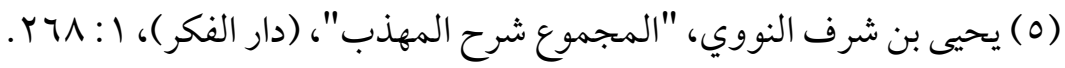

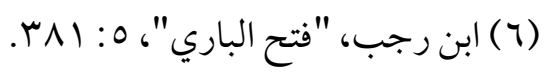

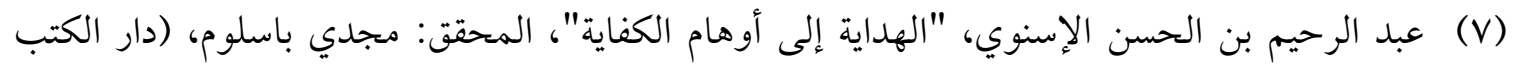

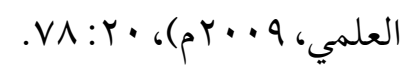

(^) عمر بن علي بن أحمد ابن الملقن، "البدر المنير في تخريج الأحاديث والأثار الواقعة في الشرح الكبير".

المحقق: مصطفى أبو الغيط وعبد الله بن سليمان وياسر بن كمال، (ط ا، الرياض: دار الهجرة للنشر والتوزيع،

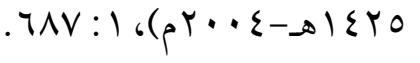

$$
\begin{aligned}
& \text { ابن كثير، "اختصار علوم الحديث"، ع r. }
\end{aligned}
$$




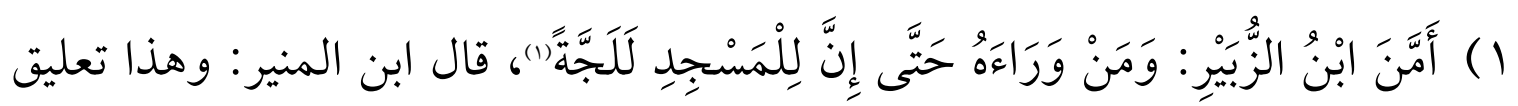
وهو بصيغة جزم فيكون صحيحا"( ).

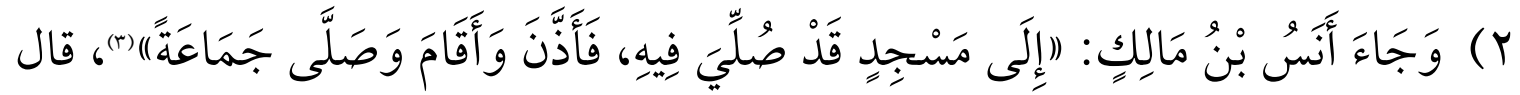
ابن حجر : رواه أبو يعلى بإسناد صحيح موقوف ().

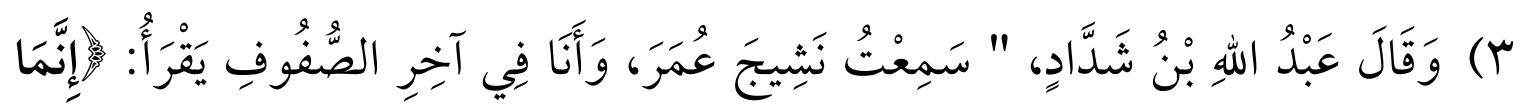

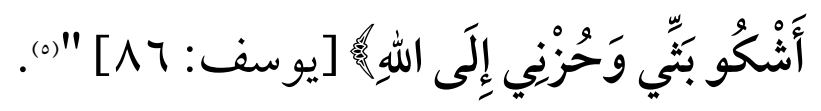

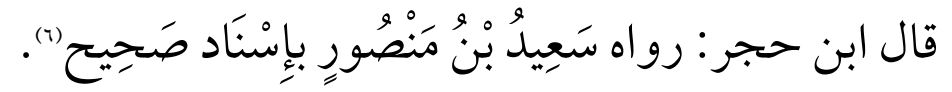

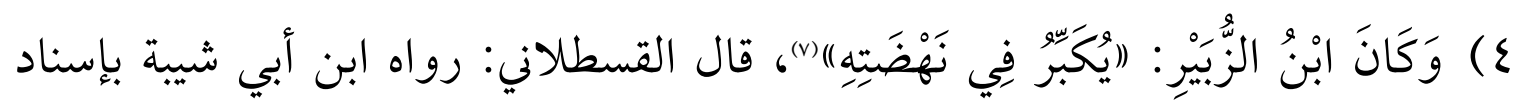
صحيح

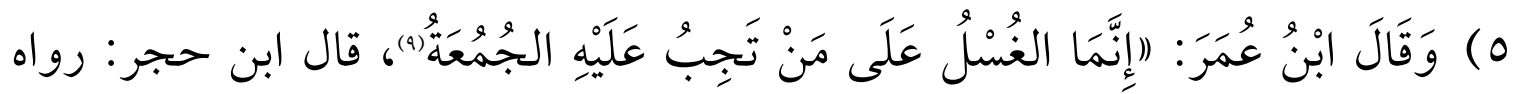
البيهقي بإسناد صحيح (1)، وصححه العيني "(1).

$$
\begin{aligned}
& \text { (1) البخاري، "صحيح البخاري"، 1:107. } \\
& \text { (ץ) ابن الملقن، "البدر المنير"، ع: •9. }
\end{aligned}
$$

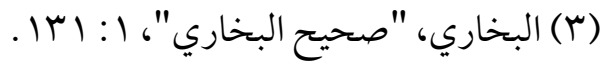

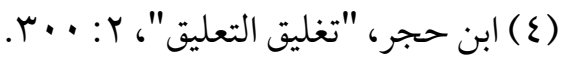

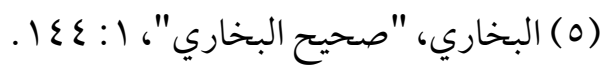

$$
\begin{aligned}
& \text { (7) ابن حجر، تغليق التعليق على صحيح البخاري، ؟: . . بـ. }
\end{aligned}
$$

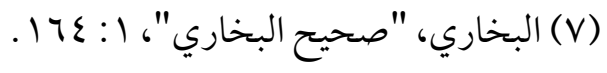

$$
\begin{aligned}
& \text { (^) القسطلاني، "إرشاد الساري"، ؟: } \\
& \text { (9) البخاري، "صحيح البخاري"، ؟: } 0 .
\end{aligned}
$$

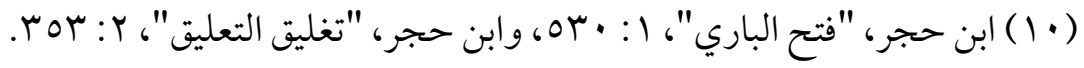

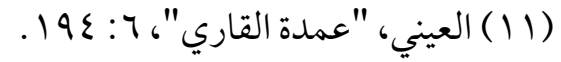




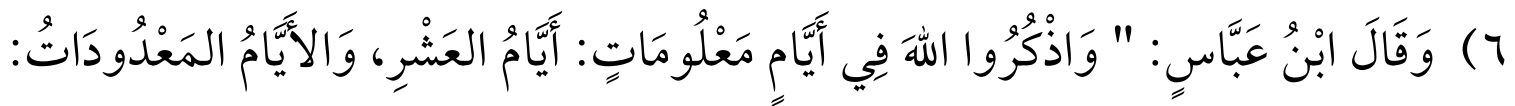
أَيَّامُ التَّشْرِيقِ (1)"، وقال ابن حجر : رواه الشافعي بسند صحيح وصححه أبو علي ابن السكن وعلقه البخاري بصيغة الجزم)

O الصورة الثانية: ما رواه البخاري موقوفًا بصيغة التمريض (r): يستعمل البخاري هذه الصيغة لعدة أسباب منها(:):

( ) ضعف الإسناد Y ) إذا ذكر المتن بالمعنى ب) إذا اختصر المتن ع ) لأنه لا يميل إلى ما في الموقوف من الناحية الفقهية، ويقول بحخلافه. وقد سأل الحافظ ابن حجر شيخه الحافظ العراقي في ذلك فقال: وقد يُستشكل ترك البخاري الجزم به مع صحته عنه؛ وذلك محمول على قاعدة ذكرها لي شيخنا أبو الفضل بن الحسين الحافظ -رحمه الله وهي: أن البخاري لا يخص صيغة التمريض بضعف الإسناد، بل إذا ذكر المتن بالمعنى، أو اختصره أتى بها أيضا لما علم من الخلاف في ذلك (ه).

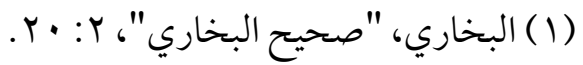

$$
\begin{aligned}
& \text { (ץ) أحمد بن علي بن حجر العسقلاني، "التلخيص الحبير في تخريج أحاديث الر افعي الكبير"، (ط ا، بيروت: دار }
\end{aligned}
$$

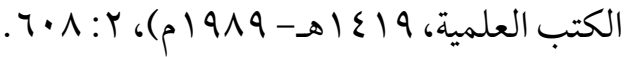

(r) انظر: أحمد عيد العطفي، م"علقات الإمام البخاري في صحيحه دراسة تحليلية". مجلة كلية الدراسات

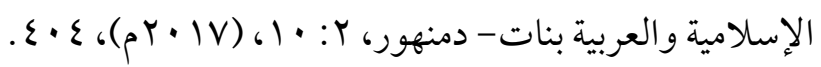

(ع) النقاط الثلاثة الأولى من (فتح الباري لابن حجر) 1: 1111، و النقطة الرابعة مأخوذة من كلام الشيخ زكريا الأنصاري (منحة الباري بشرح صحيح البخاري" r: · مب، وقد ذكر الشيخ زكريا الأنصاري أنه يذكره بصيغة

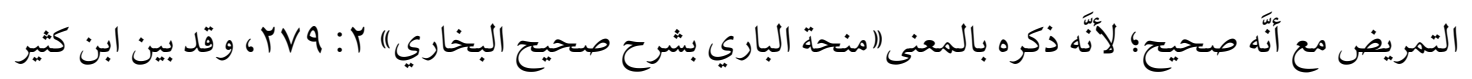
أن صيغة التمريض ليست دائمًا ضعيفة قال: وما كان منها بصيغة التمريض فلا يستفاد منها صحة ولا تنافيها أيضًا. (الباعث الحثيث إلى اختصار علوم الحديث)" ع ع.

$$
\text { ابن حجر، "فتح الباري"، إ: 1111 . }
$$


ومن أمثلة صيغة التمريض لضعف الإسناد ما ذكره البخاري فقال: وَيْذْكَرُ: (أَنَّ

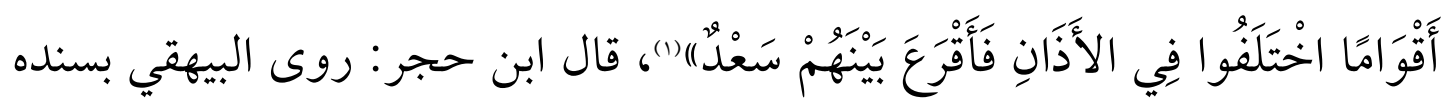
عن ابن شبرمة قال تشاجر الناس في الأذان بالقادسية فاختصموا إلى سعد فأقرع

$$
\text { بينهم وهذا منقطع ولذلك مرضه(r). }
$$

ومن أمثلة ذكر المتن بالمعنى واختصاره مع صحة صيغة التمريض: ما ذكره

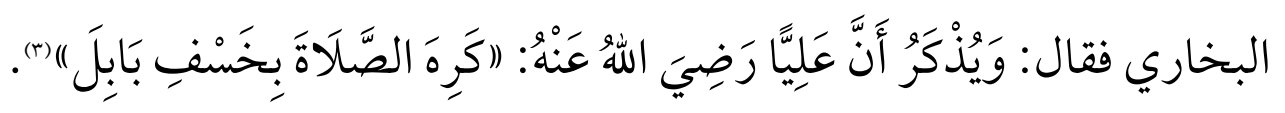
قال ابن رجب: وهذا إسناد جيد(). وقال ابن حجر: وهذا إسناد حسن (0). •ومن أمثلة ذكر صيغة التمريض لأنه لا يميل إلى ما في الموقوف من الناحية الفقهية، ويقول بخلافه.

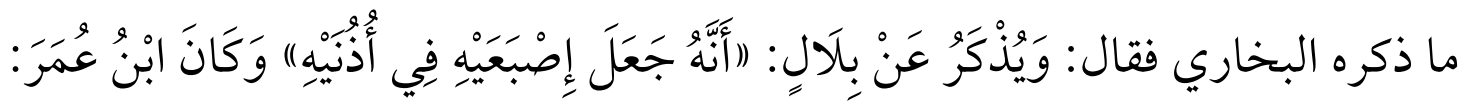

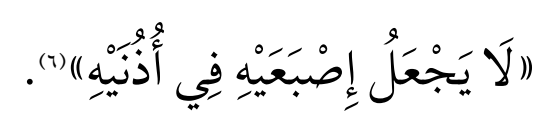

قال الشيخ زكريا الأنصاري: أنَّ ميل البخاريٌّ إلى عدم جعلهما في أذنيه، حيث عبَّر فيه

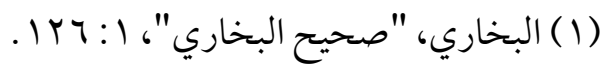

$$
\begin{aligned}
& \text { (r) ابن حجر، "تغليق التعليق"، ؟: ד Y r. }
\end{aligned}
$$

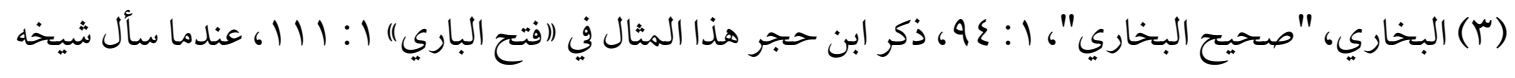
العراقي عن استشكاله صحة هذا السند فذكر الأسباب الأخرى وهي ذكر المتن بالمعنى واختصاره، وانظر مثال آخر على ذكر البخاري بصيغة التمريض مع صحة الإسناد لكونه ذكره بالمعنى (اللامع الصبيح بشرح

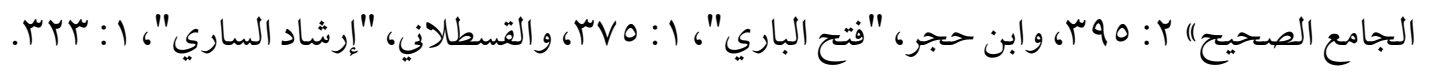

$$
\begin{aligned}
& \text { (ع) ) ابن رجب، "فتح الباري"، ؟: צrr. }
\end{aligned}
$$

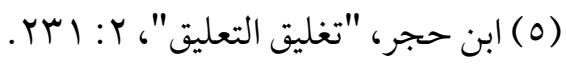

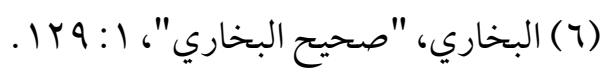




\section{بصيغة الجزم، وفي جعلهما في أذنيه بصيغة التمريض (1). \\ المطلب الثالث \\ ما رواo البخاري بصيغة قال لنا}

من إحدى استعمالات البخاري لهذه الصيغة استعمالها في الموقوفات(م). قال ابن

حجر: و الذي ظهر لي بالاستقر اء أنه إنما استعمل هذه الصيغة في الموقوفات(r).

وقد بلغ عدد المواضع التي استعمل البخاري فيها صيغة" قال لنا (7 ( ) موضعَّا

وعدد المواضع التي استعمل فيها صيغة" قال لي( سب) موضعا، فيكون المجموع

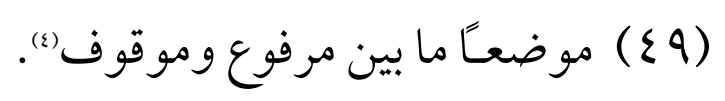

وقال بعض الباحثين: (اوباستقرائي للجامع الصحيح، مع ملاحظة المواضع التي

استعمل فيها البخاري هذه الصيغة، ثم الاستعانة بكلام الحافظ ابن حجر في توضيحها، تبين لي أن البخاري رحمه الله، استعمل صيغة "قال لنا" غالبًا في الآثار الموقوفة، التي يكون ظاهرها الوقف لكنها تحتمل الرفع وليست بصريحة فيه (م).

(1) زكريا الأنصاري، "منحة الباري بشرح صحيح البخاري"، ؟: • مب، وقال ذلك أيضًا البِرِماوي، "اللامع

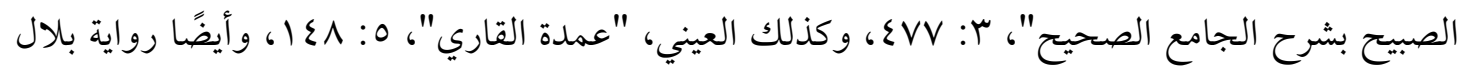

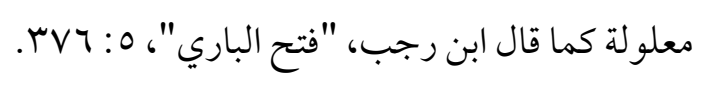

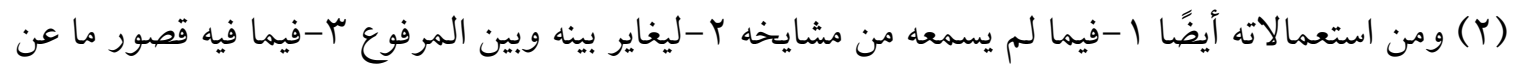

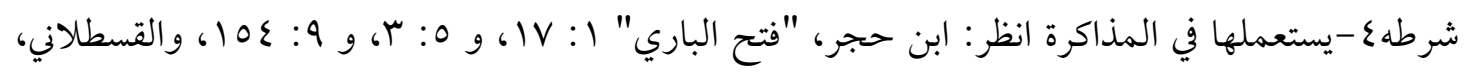

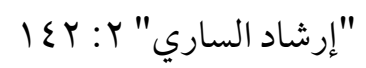

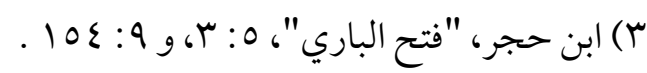

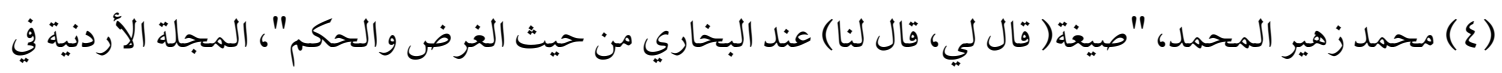

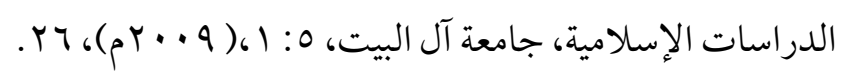

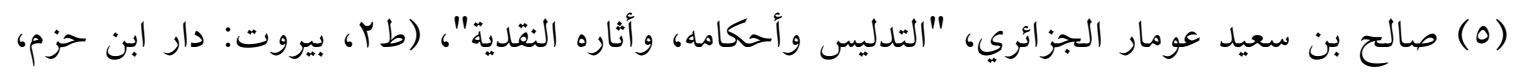

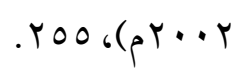




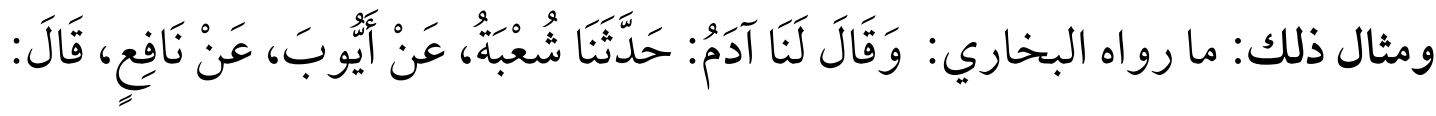

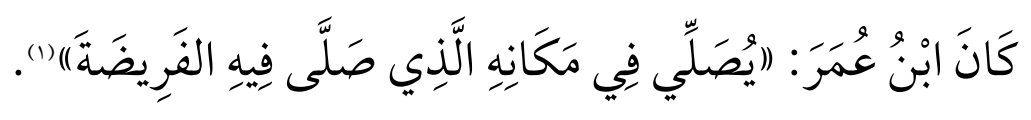

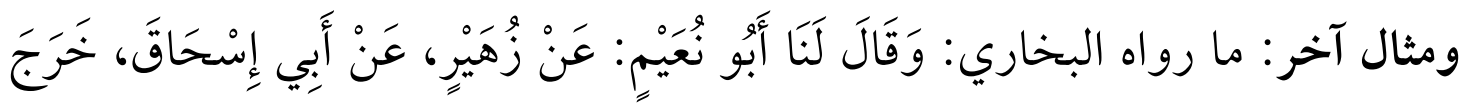

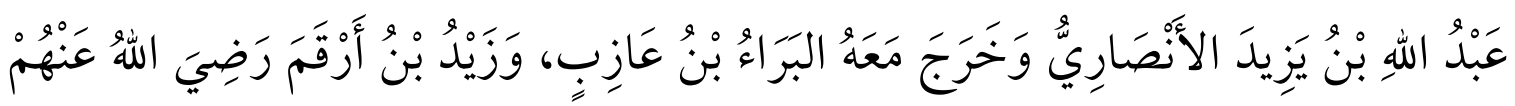

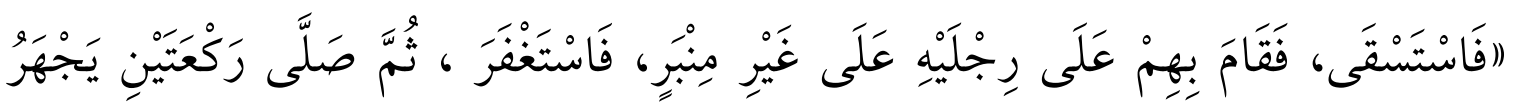

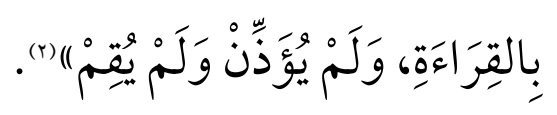

$$
\text { (1) (1) البخاري، "صحيح البخاري"، ع: } 19 \text { البخاري، "صحيح البخاري"، ؟: • ب. }
$$




\section{المبحصث الر ابع \\ منهج البخاري في سباقة الموقيح فئاث}

والمقصود بذلك أن البخاري أحيانًا يذكر عدة أقوال أو أفعال مجتمعات عن صحابي

واحد في نفس الباب في سياق واحد، أو يذكر عدة صحابة، ولهم قول، أو فعل واحد في

سياق واحد، فما هو منهج البخاري في سياقه لهذا الجمع بين الموقوفات؟ المطلب الأول

جمع البخاري لأكثر مـن حديث موقوف والمتن والإسناد واحد المد

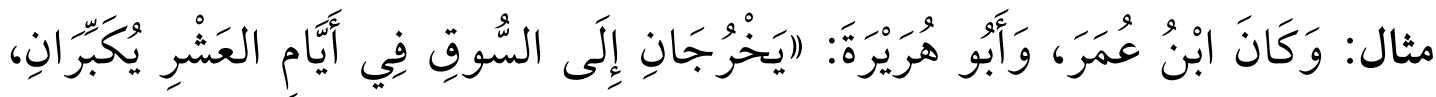

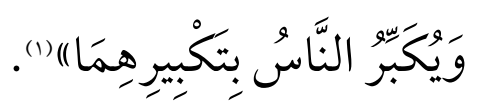

جمع البخاري بين فعل ابن عمر وفعل أبي هريرة في حديث موقوف واحد وهو الخروج إلى السوق في أيام العشر والتكبير، وعند تخريج الحديث تبين أنه حديث واحد بإسناد واحد.

قال ابن رجب: رواه أبو بكر عبد العزيز بن جعفر في ((كتاب الشافي))، وأبو بكر المروزي القاضي في ((كتاب العيدين)) من طريق عفان: نا سلام أبو المنذر عن حميد الأعرج، عن مجاهد قال: كان أبو هريرة وابن عمر يأتيان السوق أيام العشر، فيكبران، ويكبر الناس معهما، ولا يأتيان لشيء إلا لذلك(r).

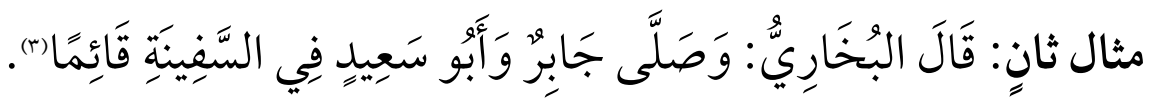
فصلاة جابر و أبي سعيد الخدري في السفينة قائمًا وهي رواية واحدة بإسناد واحد

$$
\begin{aligned}
& \text { (1) المرجع السابق. } \\
& \text { (Y) ابن رجب، "فتح الباري"، 9: } 1 \text { ه. } \\
& \text { (r) البخاري، "صحيح البخاري"، 1. 10. }
\end{aligned}
$$




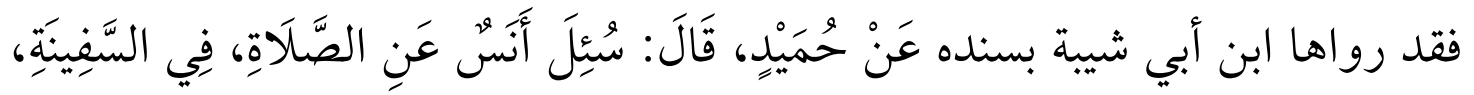

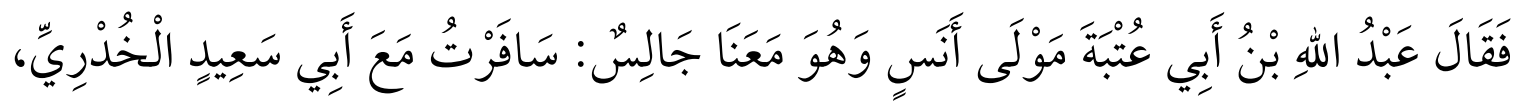

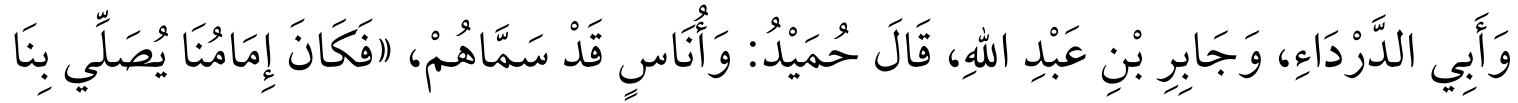

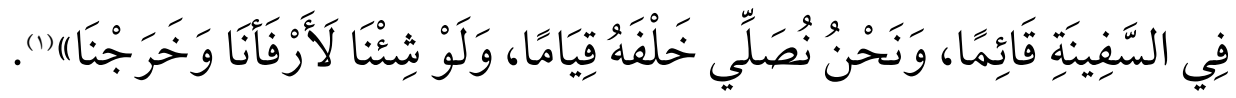

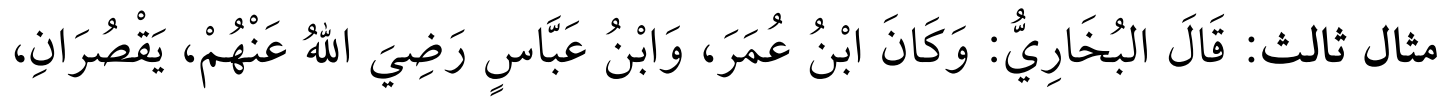

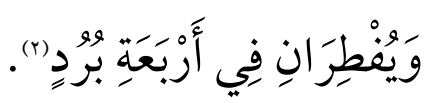

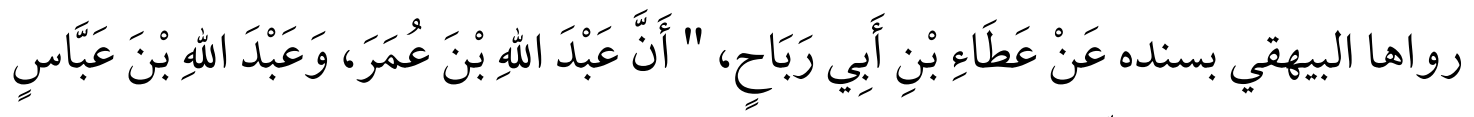

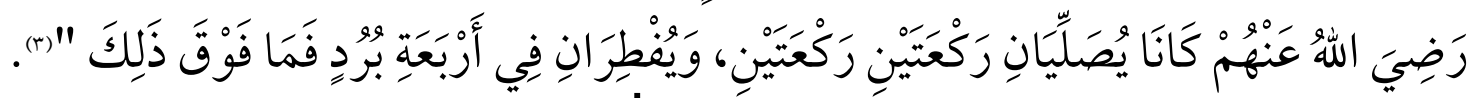

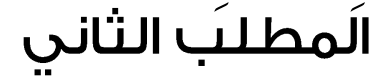 جمع البخاري للموقوفات عن الصحابي الواحد وهي أحاديث متفرقة بأسانيد مختتلغة أعوات}

وهو أن يجمع البخاري عدة أقوال، أو أفعال، أو أقوال وأفعال، عن الصحابي الواحد في مسألة معينة، وعند تخريج هذه الروايات تبين أنها روايات مختلفة، وليست رواية

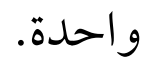

ومثاله ما ذكره البخاري في باب: يرد المصلي من مر بين يديه قال: وَرَدَّ ابْنُ عُمَرَ: فِي

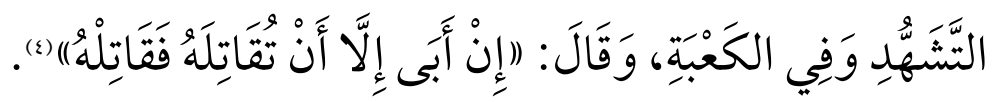

(1) أبو بكر بن أبي شيبة، "المصنف في الأحاديث والآثار"، المحقق: كمال يوسف الحوت، (ط ا، الرياض:

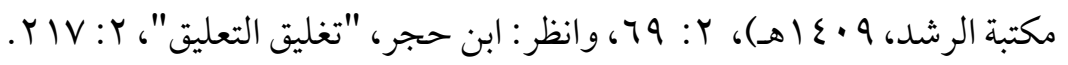

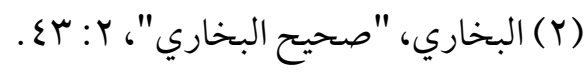
(r) أحمد بن الحسين البيهي، "السنن الكبرى". المحقق: محمد عبد القادر عطا، (ط، بيروت: دار الكتب

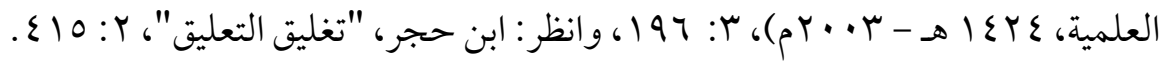

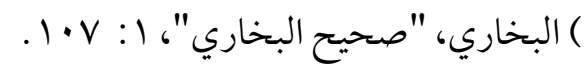


وقد بينّ العيني: "أن المروي عن ابن عمر ههنا على سبيل التعليق بثلاثة أشياء، ثم

ذكر الروايات(1)

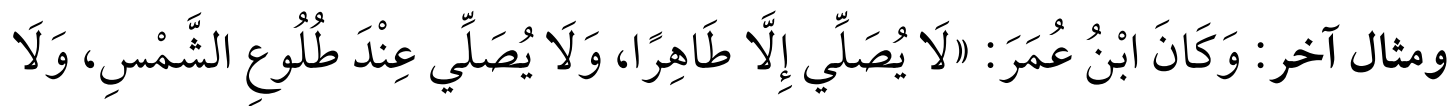

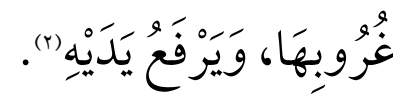

\section{المطلب الثالث}

جمع البخاري للموقوفات عن عدة صحابة وهي أحاديث مـتفرقة بأسانيد مختلفة

ومثاله: ذكر البخاري في بَاب وَقْت الجُمُعَةِة إِذَا زَالَتِ الشَّمْسُ وَكَذَلِكَ يُوْوَى عَنْ عُمَرَ،

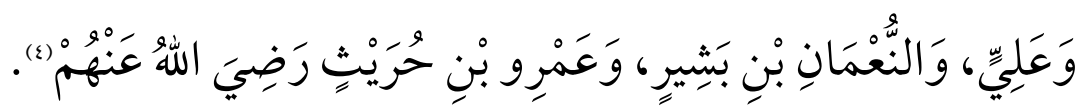

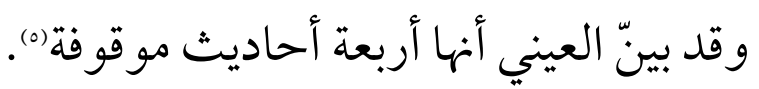

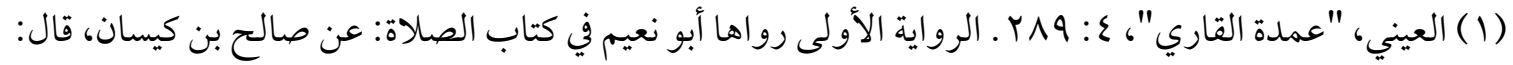

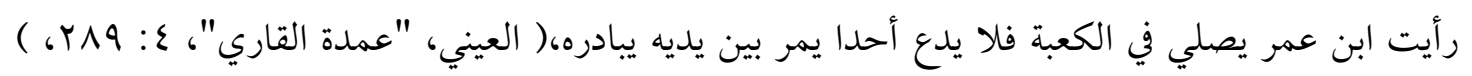

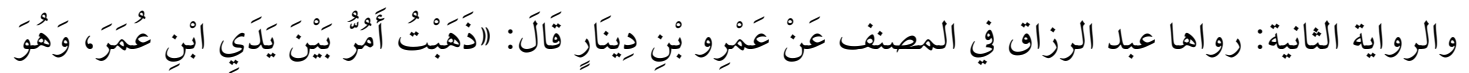

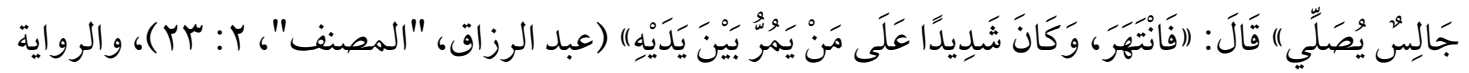

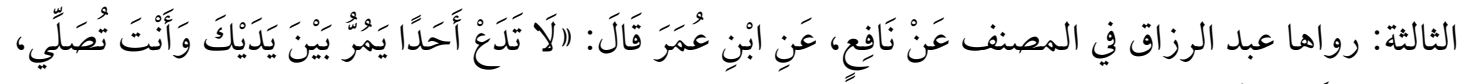

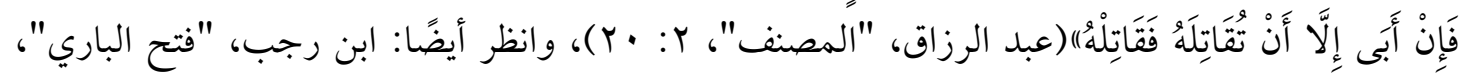

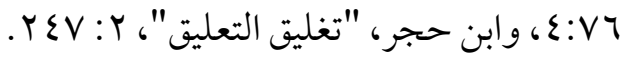

$$
\begin{aligned}
& \text { (Y) البخاري، "صحيح البخاري"، Y : YV. }
\end{aligned}
$$

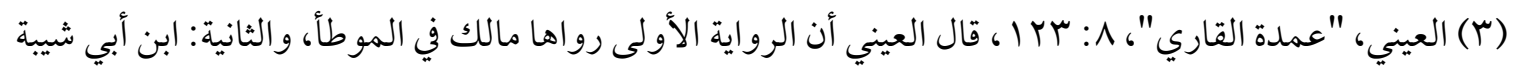

$$
\begin{aligned}
& \text { في (مصنفه)، والثالثة: البخاري في كتاب (رفع اليدين) المفرد. }
\end{aligned}
$$

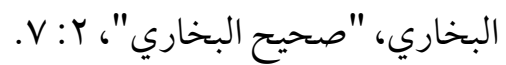

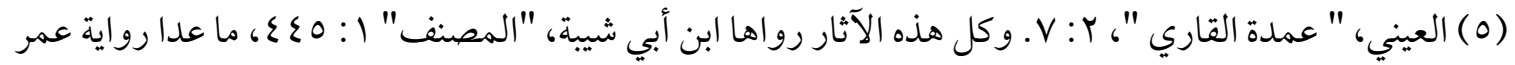

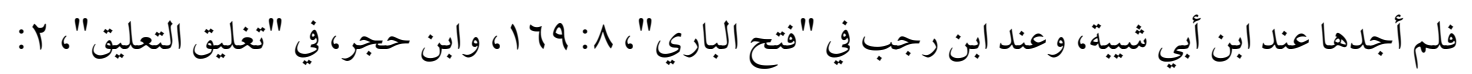

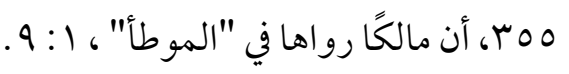




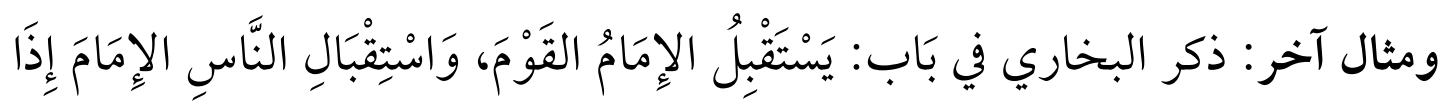

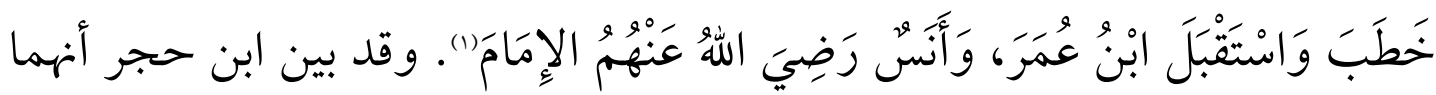
حديثان موقوفان(r) (r) (r)

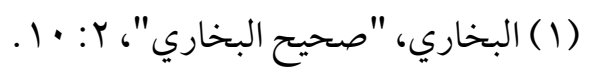

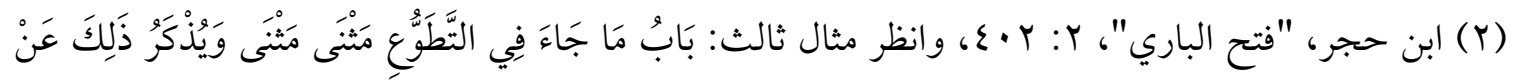

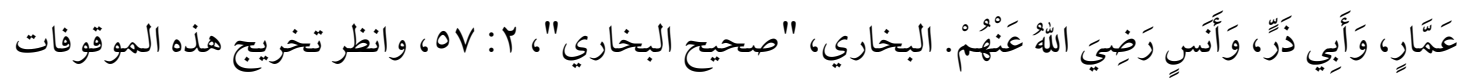

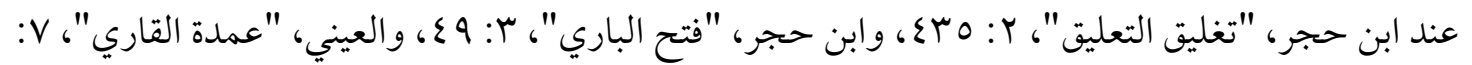




\section{المبحث الخامس}

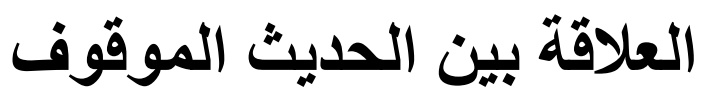

\section{وبين ترجمة الباب والحديث المرفوع في الباب عند البخاري}

قد تكون العلاقة بين الحديث الموقوف وترجمة الباب والحديث المرفوع بينّة واضحة لا تحتاج إلا إعمال فكر كبير، وقد تكون خفية لا تُعرف إلا بإمعان النظر الطويل، ومر اجعة كلام العلماء في بيان تلك العلاقة. المطلب الأول

\section{العلاقة بين الحديث الموقوف وترجمة الباب البوف}

الصورة الأولى: علاقة الحديث الموقوف بترجمة الباب ظاهرة:

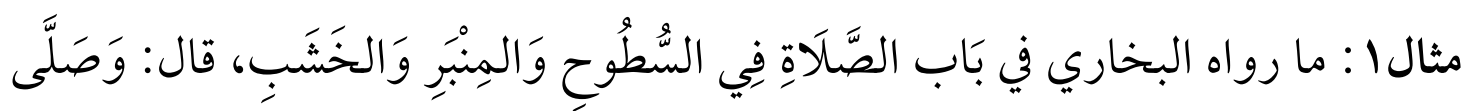

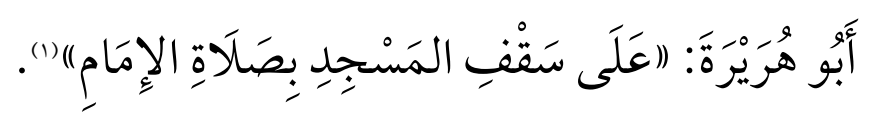

قال العيني: مطابقة هذا الأثثر للترجمة ظاهرة وهي في قوله: (و السطوح) (r).

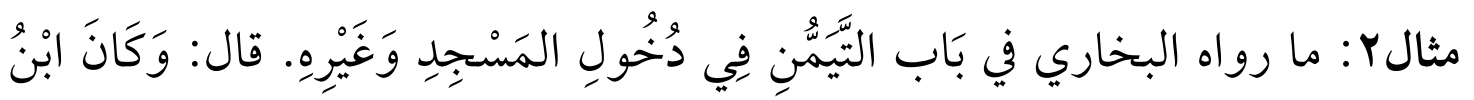

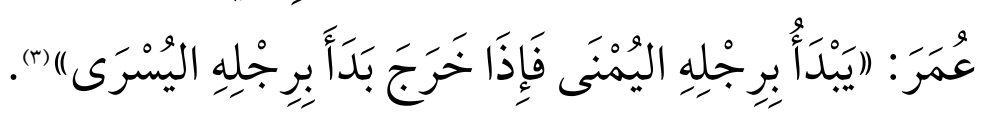

قال العيني: هذا باب في بيان البداءة باليمين في دخول المسجد وغيره. وكان ابن عمر

يبدأ بر جله اليمنى فإذا خرج بدأ بر جله اليسرى مطابقة هذا الأثر للترجمة ظاهرة").

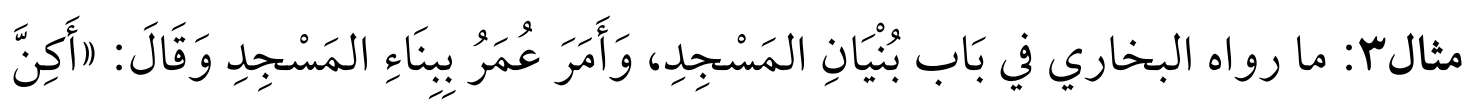

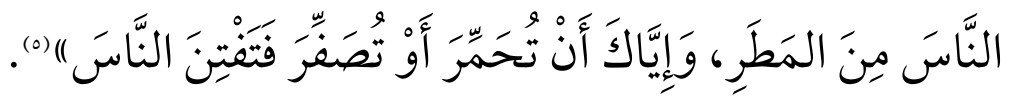

$$
\begin{aligned}
& \text { (1) البخاري، "صحيح البخاري"، 1) 10. (1). }
\end{aligned}
$$

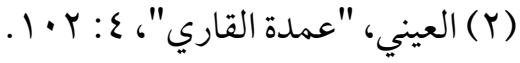

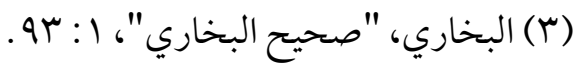

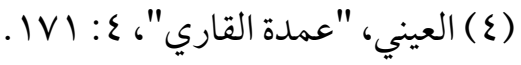

$$
\begin{aligned}
& \text { (0) البخاري، "صحيح البخاري"، (1:97. }
\end{aligned}
$$


قال العيني: مطابقته للترجمة ظاهرة جدًا، و المر اد من المسجد: مسجد رسول اللها.). الصورة الثانية: علاقة الحديث الموقوف بترجمة الباب خفية:

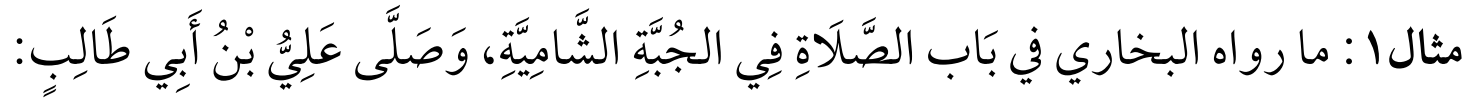

$$
\text { فِي ثَوْبِ غَيْرِ مَفْصُورِ "(r) }
$$

ومعنى غير مقصور: أي خام و المر اد أنه كان جديدًا لم يغسل (r).

فما علاقة غير مقصور (لم يُغسل) بالجبة الشامية؟ وفي إدراك تلك العلاقة كأنّه استُشكل على العيني سبب ذكر البخاري لهذا الحديث الموقوف في هذا الباب ولم يكن جو ابه شافيًا فقال العيني: فإن قلت: ما مناسبة أثر الزهري وعلي للترجمة؟ قلت-القائل العيني: لما ذكر أثر الحسن المطابق للترجمة ذكر الأثرين الآخرين

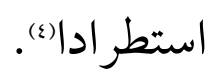

قلنا: ما قاله العيني - رحمه الله - ليس بصواب، ولتوضيح علاقة غير مقصور (لم يُغسل) بالجبة الشامية، رجعنا إلى تخريج هذا الأثر فقد رواه ابن أبي شيبة من طريق

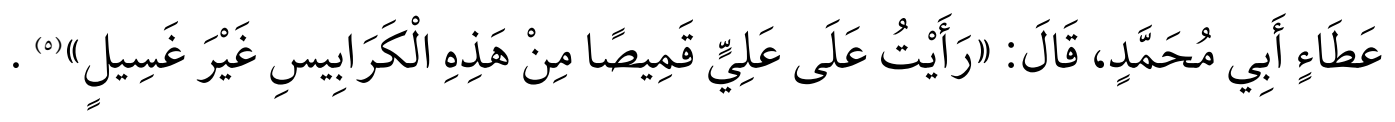

$$
\begin{aligned}
& \text { (1) العيني، "عمدة القاري"، ع: ع •r. }
\end{aligned}
$$

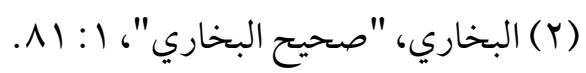

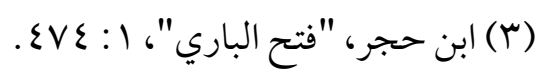

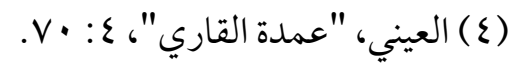

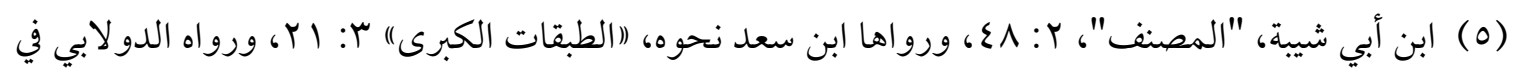

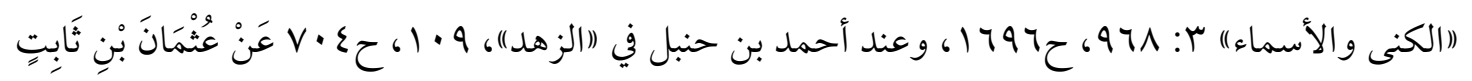

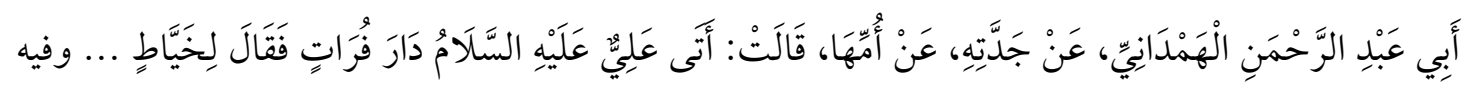

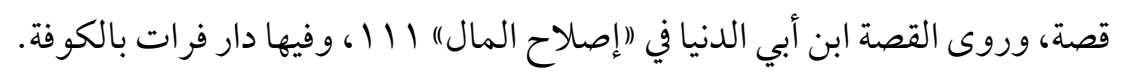


فتتبن أن القميص غَيْر غَسِيلٍ هو من الْكَرَابِيسِ، وعند الرجوع لكتب اللغة قال ابن

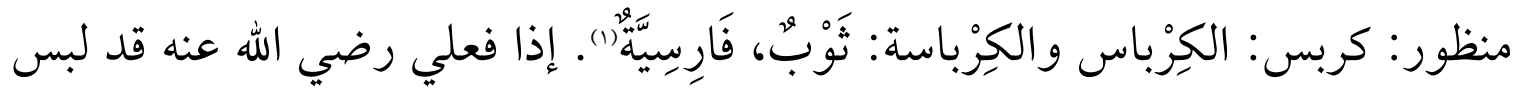
ثيابًا صنعها الكفار وصلى بها من غير غسيل. فتبين مراد البخاري من حديث علي رضي اله عنه الموقوف في أن ثوبه مصنوع في بلاد فارس، فتبين مناسبته الدقيقة للترجمة التي عقدت لبيان جواز الصلاة في ثياب الكفار ما لم يتحقق نجاستها وإنما عبر بالشامية مر اعاة للفظ الحديث (ه). مثال : ما رواه البخاري في بَاب حَكِّ المُخَاطِ بِالحَحَى مِنَ المَسْجِدِ وَقَالَ ابْنُ

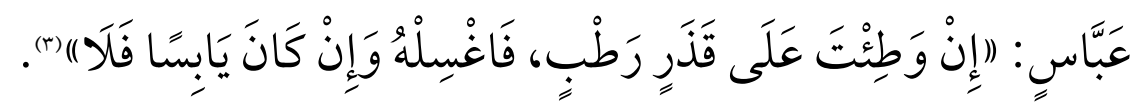

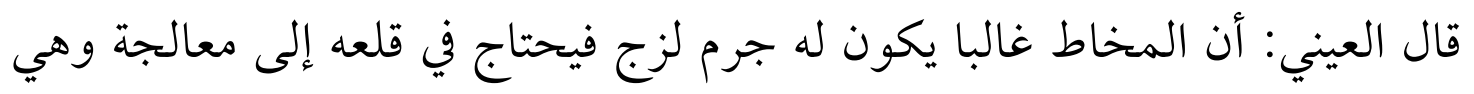
بالحصى ونحوه... ويمكن أن يوجه له تناسب بو جهه وهو أن يقال: المذكور في حديث الباب حك النخامة بالحصى، وفي الترجمة حك المخاط بالحصى، وذا يدل على أنه كان يابسا إذ الحك لا يفيد في رطبه لأنه يتشر به ويزداد التلوث، فظهر الفرق بين رطبه ويابسه وإن لم يصرح به في ظاهر الحديث، فقي الرطب يزال بما تمكن إزالته به، وفي اليابس بالحصاة ونحوها، فكذلك في أثث ابن عباس: الفرق حيث قال: إن كان رطبا فاغسله وإن كان يابسا فلا، أي: فلا يضرك وطؤه، فتكون المناسبة بينهما من هذه

$$
\begin{aligned}
& \text { (1) ) ابن منظور، "لسان العرب"، } 7 \text { (190 ا. } \\
& \text { (Y) ابن حجر، "فتح الباري"، IVIr) }
\end{aligned}
$$

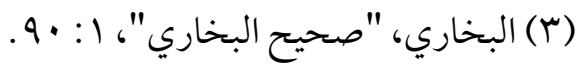

$$
\begin{aligned}
& \text { (ع) العيني، "عمدة القاري"، ع: 101. }
\end{aligned}
$$




\section{الصورة الثالثة: بيان ما أُبهم حكمه من ترجمة الباب:}

ومثال ذلك: ما رواه البخاري في بَاب الصَّلَاةِ فِي مَوَاضِعِ الخَسْفِ وَالعَنَابِ، قال:

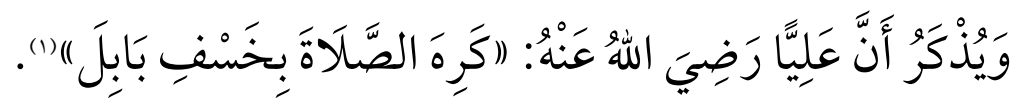

فقي ترجمة الباب لم يبين حكم الصلاة في مواضع الخسف والعذاب، ولما ذكر أثثر

$$
\text { علي بينّ أن الصلاة مكروهة في هذه المو اضع }
$$

قال العيني: أي: هذا باب في بيان حكم الصلاة في الأمكنة التي خسفت أو نزل عليها العذاب، وأبهم حكمه حيث لم يبين: هل هي مكروهة أو غير جائزة؟ ولكن تقديره:

$$
\text { يُمره لدلالة أثر علي على ذلك(r). }
$$

\section{المطلب الثاني}

\section{العلاقة بين الحديث الموقوف والحديث المـرفوع في الباب}

الصورة الأولى: علاقة الحديث الموقوف بالحديث المرفوع في الباب ظاهرة:

ومثال ذلك: ما رواه البخاري في بَاب الصَّلَاِِ عَلَى الفِرَاشِ قال: وَصَلَّلى أَنَُّ عَلَى

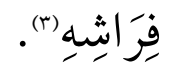

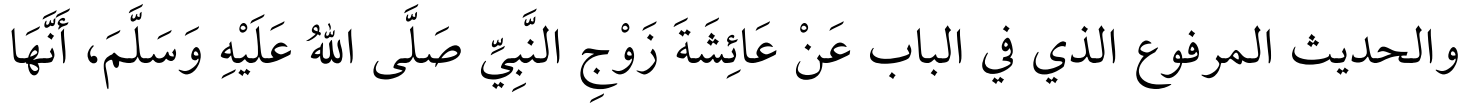

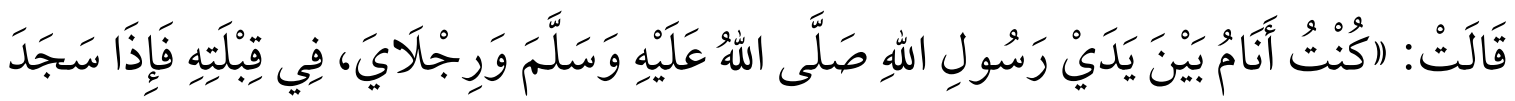

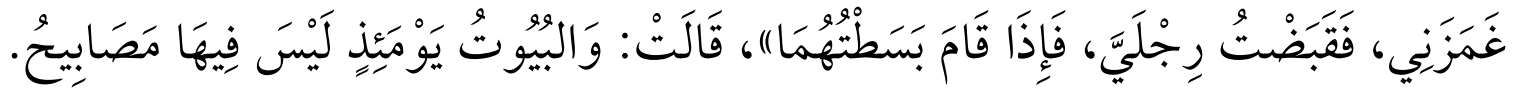

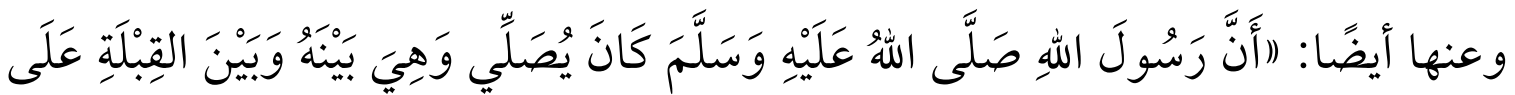

$$
\begin{aligned}
& \text { (1) البخاري، "صحيح البخاري"، (1 ؟9. } \\
& \text { (Y) العيني، "عمدة القاري"، ع: 111. } \\
& \text { (r) البخاري، "صحيح البخاري"، 1. 17. }
\end{aligned}
$$




\section{فِرَاشِ أَهْلِهِ اعْتِرَاضَ الجَنَازَةِ)(1).}

فالحديث الموقوف يدل على جواز الصلاة على الفراش، وأما علاقته بالحديث المرفوع فالحديث الثاني فيه النص على فراش أهله، واما الحديث الأول: فنوم عائشة رضي الله عنها في قبلة رسول الله صلى الله عليه وسلم، وغمزها دلالة على صلاته على الفرش.

قال ابن رجب: وجه الاستدلال بهذا الحديث على جواز الصلاة على الفراش: أن عائشة - رضي الله عنها - كانت تنام على فراش النبي - صلى الله عليه وسلم - الذي ينام هو وعائشة عليه، وكان يقوم فيصلي من الليل وهي نائمة معترضة بين يديه على الفراش، وكانت رجلاها في قبلته، فإذا أراد أن يسجد غمزها فقبضت رجلها ليسجد في موضع، وهذا يدل على أنه كان يسجد على طرف الفراش الذي كانت نائمة عليه، وكانت رجلاها عليه). (r)

ومثال آخر : ما رواه البخاري في بَابُ الإِبْرَادِ بِالظُهْرِ فِي السَّفَِِ (م)، والحديث المرفوع

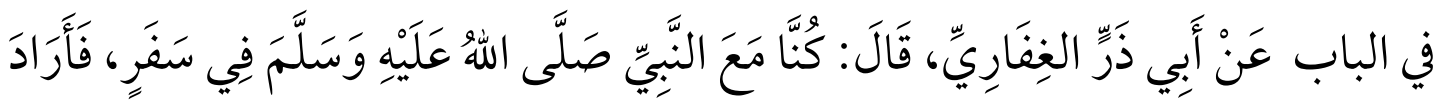

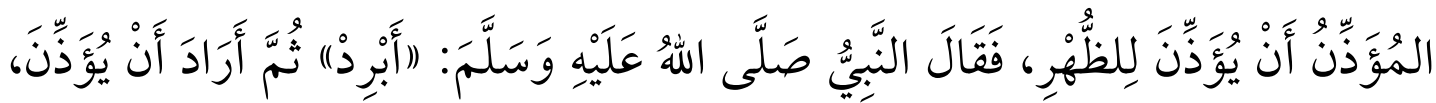

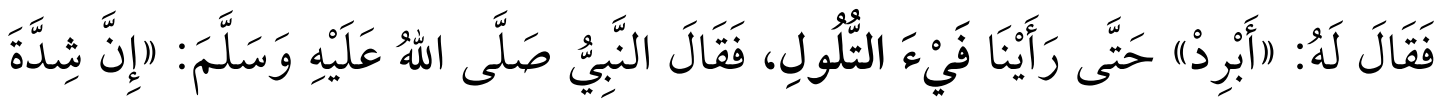

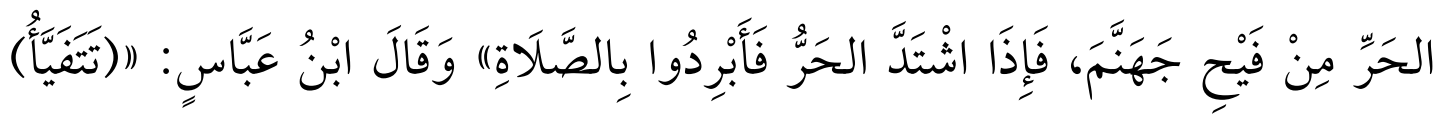

$$
\begin{aligned}
& \text { (1) البخاري، "صحيح البخاري"، 1:14. } \\
& \text { (r) ابن رجب، "فتح الباري"، r r V. }
\end{aligned}
$$

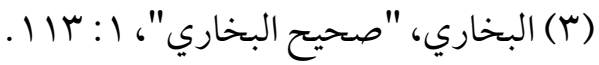




\section{(1) (1)}

قال العيني: ومناسبة ذكر هذا عن ابن عباس لأجل ما في حديث الباب: (حتى رأينا

فيء التلول) (")

\section{الصورة الثانية: علاقة الحديث الموقوف بالحديث المرفوع في الباب خفية:}

ومثال ذلك: ما رواه البخاري في بَابُ الصَّلَةِ عَلَى الحَصِيرِ وَصَلَّى جَابِرُ بْنُ عَبْدِ اللهِ

$$
\text { (افِي السَّفِينَة قَائمًَا)(").). }
$$

والحديث المرفوع الذي في الباب رواه البخاري من طريق أَنَس : فَقُمْتُ إلَّلى حَصِيرِ

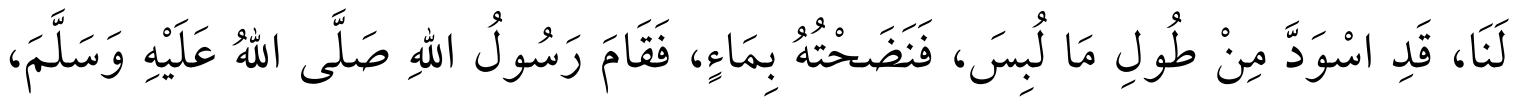

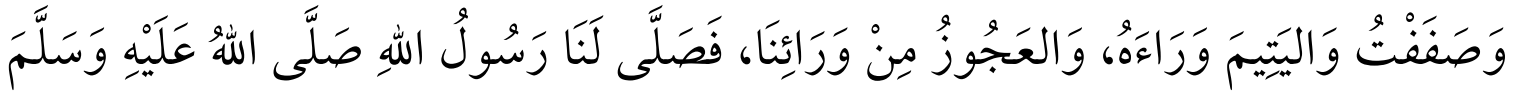

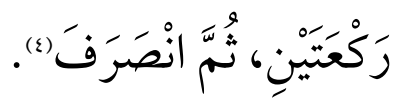

\section{فما علاقة الموقوف وهو الصلاة في السفينة بالحديث المرفوع ؟}

قال ابن رجب: ذكر الصلاة في السفينة؛ لأن المصلي في السفينة لا يمكنه الصلاة على التراب، ولا على وجه الأرض، وإنما يصلي على خشب السفينة، أو ما فوقه من البسط أو الحصير أو الأمتعة والأحمال التي فيهاهـ.

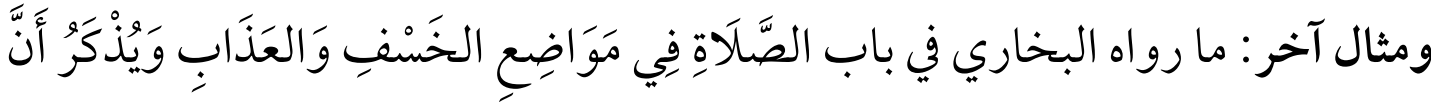

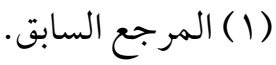

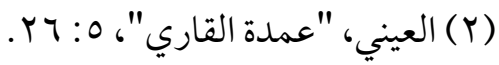

$$
\begin{aligned}
& \text { (Y) البخاري، "صحيح البخاري"، إ:10. }
\end{aligned}
$$

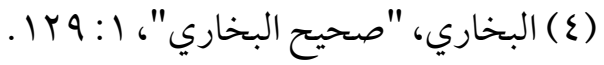

$$
\begin{aligned}
& \text { (0) ابن رجب، "فتح الباري"، ؟: } 1 \text { ـ . }
\end{aligned}
$$




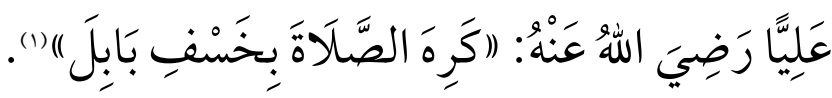

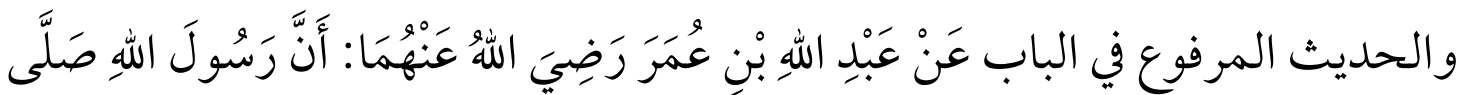

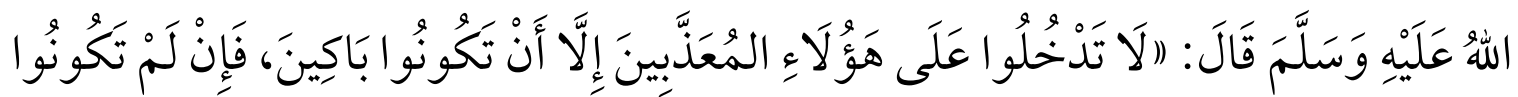

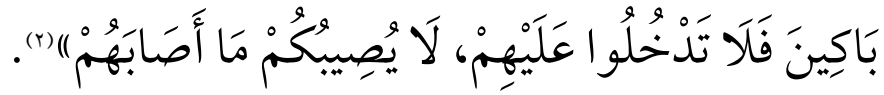
وجه الخفاء بين أثر علي والحديث المرفوع كما استشكلها ابن بطال: أن الحديث المرفوع يدل على إباحة الدخول في مواطن العذاب على وجه البكاء والاعتبار، وأن من صلى هناك لا تفسد صلاته؛ لأن الصلاة موضع بكاء وتضرع وخشوع واعتبار، فإن صلى هناك غير باكٍٍ لم تبطل صلاته، وأثر علي يدل على كراهية الصلاة في هذه المواطن(r)، فكيف يجمع بين جواز دخولها باكين والصلاة فيها حتى ولو غير باكين وبين كر اهية الصلاة فيها؟

قال ابن حجر في الرد على ابن بطال: كأنه يشير إلى عدم مطابقة الحديث لأثر علي قلت و الحديث مطابق له من جهة أن كلا منهما فيه ترك النزول كما وقع عند المصنف في المغازي في آخر الحديث ثم قنع صلى الله عليه وسلم رأسه وأسرع السير حتى أجاز الو ادي فدل على أنه لم ينزل ولم يصل هناك كما صنع علي في خسف بابل (2). وقال العيني: هذا الحديث مطابق لآثر علي من حيث عدم النزول من النبي لما مر

$$
\begin{aligned}
& \text { (1) البخاري، "صحيح البخاري"، (: ع9 . } \\
& \text { (Y) البخاري، "صحيح البخاري"، ( } 9 \text { (Y). }
\end{aligned}
$$

(r) علي بن خلف بن عبد الملك ابن بطال، "شرح صحيح البخاري". تحقيق: أبو تميم ياسر بن إبراهيم، (طr،

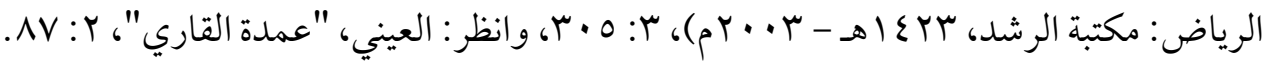

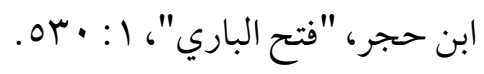


بالحجر ديار ثمود في حال توجهه إلى تبوك، وفعل علي كذلك حيث لم ينزل لما أتى

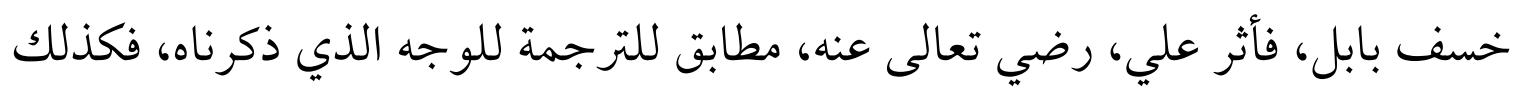
حديث ابن عمر مطابق للترجمة، لأن المطابق للمطابق للشيء مطابق لذلك الشيء،

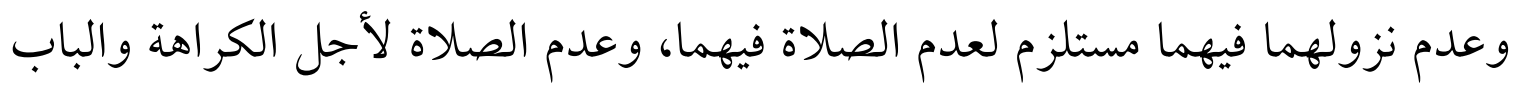
معقود لبيان الكراهة، فحصلت المطابقة فافهم"(1). 


\section{المبحش السبادس}

\section{منهج البخاري في ذكر الموقوفات للاستدلال الفقهي}

اشتهر قول جمع من الفضلاء: أن فقه البخاري في تراجمه(1)، وهذه التراجم تحتاج إلى ما يبينها ويوضحها ويُستشهد لها؛ لذلك كانت الموقوفات إحدى مصادر فقه البخاري، ويظهر فقه البخاري في الموقوفات فيما يلي: أولًا: يستنبط البخاري الحكم الشرعي من الموقوفات:

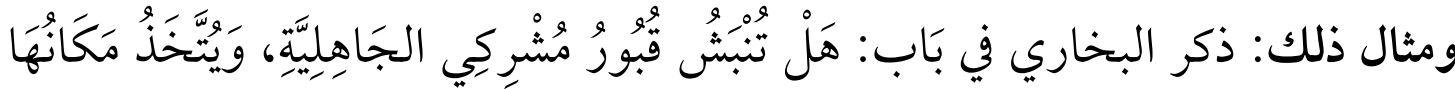

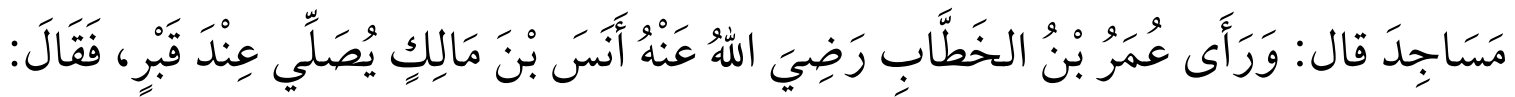

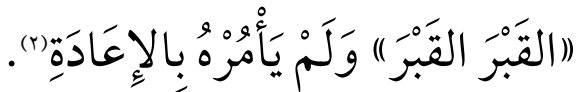

قال ابن حجر: وقوله ولم يأمره بالإعادة استنبطه من تمادي أنس على الصلاة ولو كان ذلك يقتضي فسادها لقطعها واستأنف (r). ثانيًا: يذكر البخاري الموقوفات لتدل على اختيار ما تضمنته عنده:

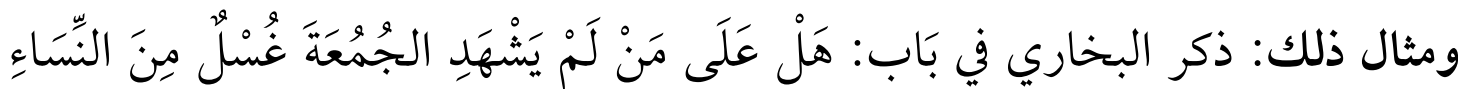

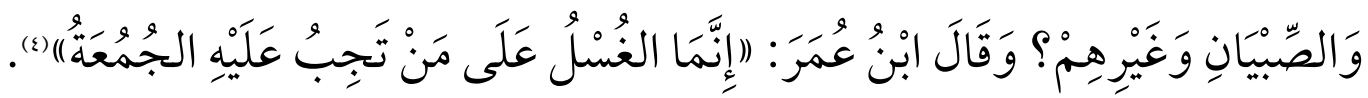
قال ابن حجر: وقد تقرر أن الآثار التي يوردها البخاري في التراجم تدل على اختيار ما تضمنته عنده فهذا مصير منه إلى أن الغسل للجمعة لا يشرع إلا لمن وجبت عليه (0).

$$
\begin{aligned}
& \text { (1) ابن حجر، "فتح الباري"، (؛ با. }
\end{aligned}
$$

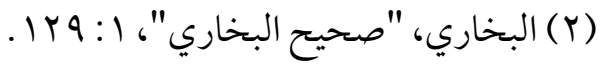

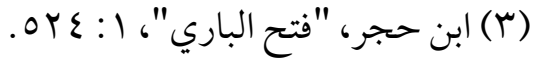

$$
\begin{aligned}
& \text { (ع) البخاري، "صحيح البخاري"، ؟:0 }
\end{aligned}
$$

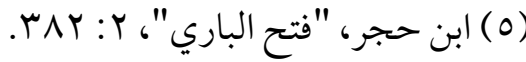




\section{ثالثًا: يجمع البخاري بين حديثين موقوفين ظاهرهما الاختلاف في المسألة الفقهية:}

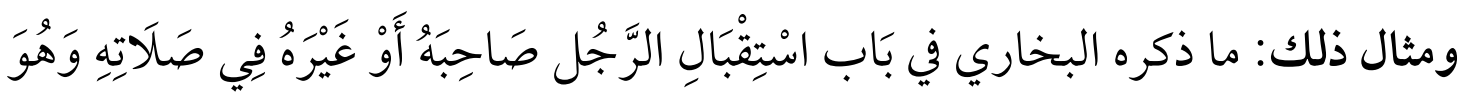

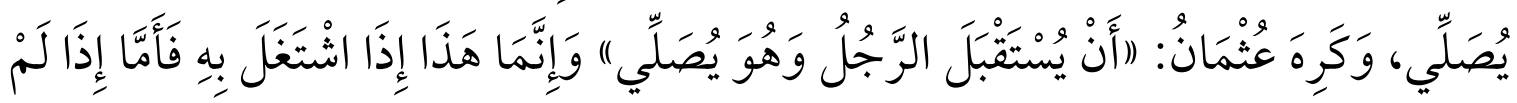

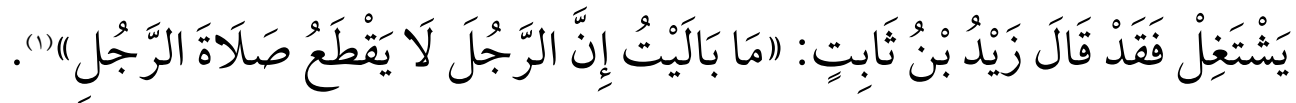

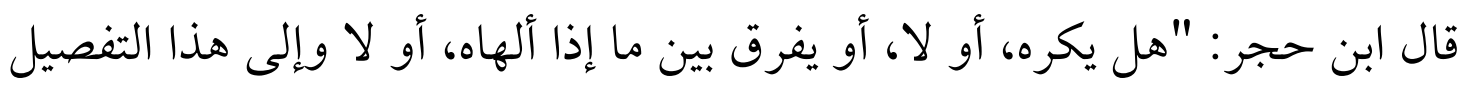
جنح المصنف وجمع بين ما ظاهره الاختلاف من الأثرين اللذين ذكرهما عن عثمان

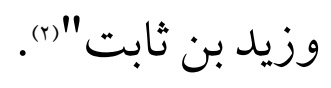

قال ابن الملقن: "هذا من كلام البخاري يشير به إلى أن مذهبه ههنا بالتفصيل، وهو أن استقبال الرجل الرجل في الصلاة إنما يكره إذا اشتغل المستقبل المصلي، لأن علة إنة الكراهة في كف المصلي عن الخشوع وحضور القلب، وأما إذا لم يشغله فلا بأس به" إن.

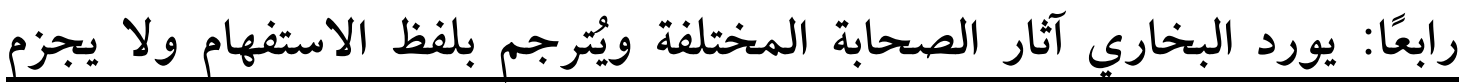
بالحكم الثرعي

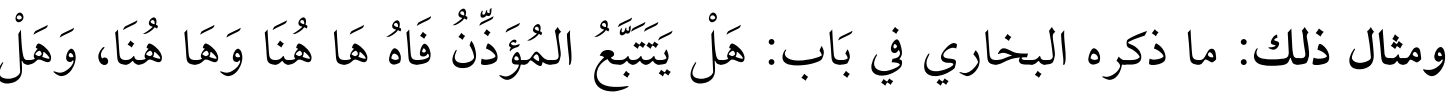

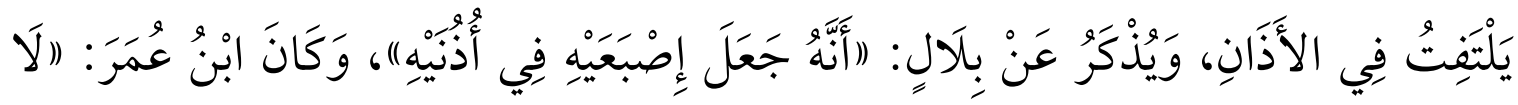
يَجْعَلُ إِصْبَعَيْهِ فِي أَذْنَيْهِ|(s). قال ابن حجر - عن أثر بلال، وابن عمر في جعل الإصبع في الأذن، وعدمه-: وبهذا تعرف مناسبة ذكره لهذه الآثار.

$$
\begin{aligned}
& \text { (1) البخاري، "صحيح البخاري"، 1: 1. 1. }
\end{aligned}
$$

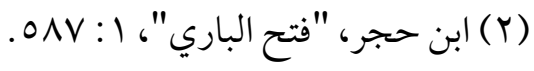

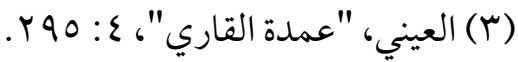

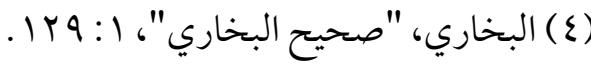


ففي هذه الترجمة أوردها بلفظ الاستفهام، ولم يجزم بالحكم لاختلاف أقوال الصحابة فيها').

\section{خامسًا: يورد البخاري الموقوفات لبيان اختلاف رأيه مع الفقهاء:}

أي أن البخاري يورد الموقوفات على الصحابة لبين الخلاف في المسألة الفقهية، والردعلى المخالف.

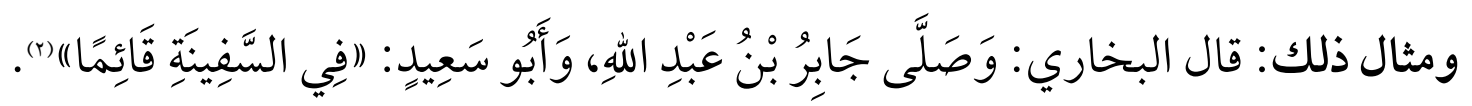
قال ابن حجر: وأشار البخاري إلى خلاف أبي حنيفة في تجويزه الصلاة في السفينة قاعدا مع القدرة على القيام"(r).

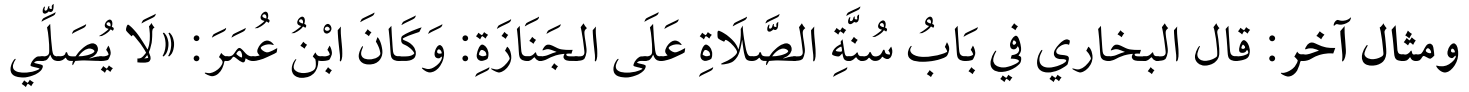
إِلَّ طَاهِرَا (8) قال ابن بطال: غرض البخاري الرد على الشعبي، فإنه أجاز الصلاة على الجنازة بغير

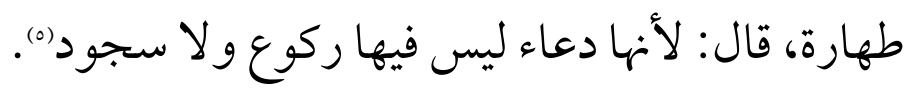

$$
\begin{aligned}
& \text { (1) ابن حجر، "فتح الباري"، ؟: } 110 \\
& \text { (Y) البخاري، "صحيح البخاري"، I. 10. }
\end{aligned}
$$

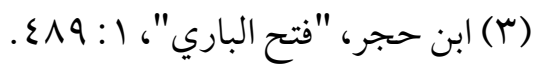

$$
\begin{aligned}
& \text { (ع ) البخاري، "صحيح البخاري"، ؟ : 1V. }
\end{aligned}
$$




\section{الخاتمة و النتائج}

الحمد لله رب العالمين والصلاة على محمد رسول رب العالمين ،،،

توصلت من خلال هذه الدراسة إلى مجموعة من النتائج منها:

1) إن المقصود من تصنيف البخاري لكتابه الصحيح هو الأحاديث الصحيحة المسندة، أما الموقوفات فقد جاءت لاستكمال مقاصد أخرى في الصحيح. r) التمييز بين الحديث الموقوف، وغيره من المرفوع والمقطوع قد يكون واضحًا وقد يكون خفيًا يحتاج إلى تصريح من أحد العلماء أو الوقوف على الرواية الأصلية.

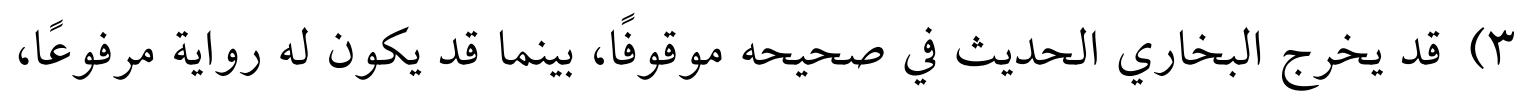
لعلة ظهرت عند البخاري رجح فيها الوقف على الرفع. ع) يورد البخاري الموقوفات بصيغ عديدة مسندة، أو معلقة، وهي الغالبة، وقد تكون بصيغة قال لنا، أو بصيغة الجزم، أو بصيغة التمريض. 0) صيغة الجزم صحيحة إلى من علقه عنه، وصيغة التمريض لا تعني بالضرورة الضعف بل يستعملها البخاري لعدة غايات.

7) يجمع البخاري أحيانًا بين عدة موقوفات من أقوال أو أفعال صحابي واحد، أو يذكر عدة صحابة ولهم قول واحد أو فعل واحد في حديث واحد، فقد يكون هذا الجمع في أصل الرواية مجموعًا، وقد يكون متفرقًا بعدة أحاديث. ليُخرج البخاري الحديث الموقوف في صحيحه؛ لمّا له من علاقة وطيدة بترجمة الباب والحديث المرفوع، فقد تكون هذه العلاقة بيّنة واضحة لا تحتاج إلى كبير

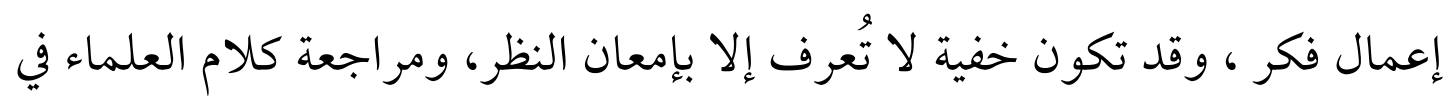

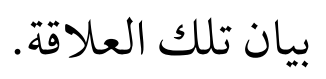




$$
\begin{aligned}
& \text { 1) الموقوفات إحدى مصادر فقه البخاري من استنباط، أو اختيار رأي عنده، أو بيان } \\
& \text { مخالفة غيره من الفقهاء. } \\
& \text { أبرز التوصيات: } \\
& 1 \text { - دراسة الأحاديث الموقوفة في جميع صحيح البخاري. } \\
& \text { r - إبراز أهمية الموقوفات في صحيح البخاري. }
\end{aligned}
$$


ملحق: إحصائيات الموقوفات في صحيح البخاري في كل كتاب

\begin{tabular}{|c|c|c|c|c|c|c|c|c|c|c|}
\hline 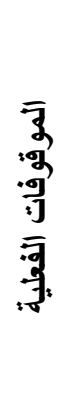 & 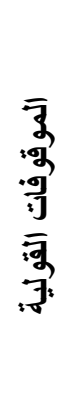 & 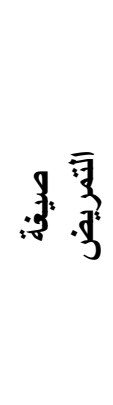 & 承 & 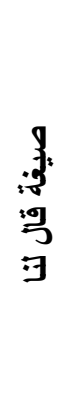 & 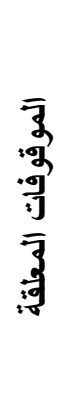 & 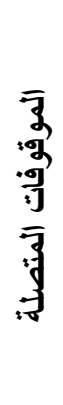 & 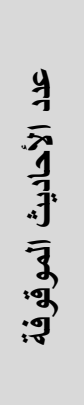 & 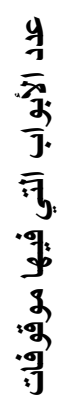 & 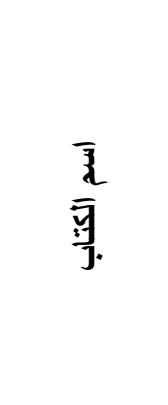 & 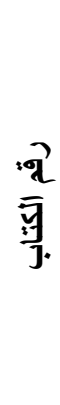 \\
\hline 11 & 9 & 1 & 19 & --- & $r$. & --- & $r$. & 11 & الصَتَّابَُُة & $\Lambda$ \\
\hline --- & 1 & --- & 1 & --- & 1 & --- & 1 & 1 & 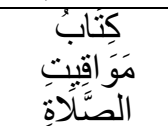 & 9 \\
\hline IV & $r$ & $r$ & 10 & 1 & 11 & 1 & 19 & $1 \varepsilon$ & كِتابُ الأذَان & 1. \\
\hline 7 & $r$ & $\varepsilon$ & $\varepsilon$ & --- & $\wedge$ & --- & $\Lambda$ & 0 & 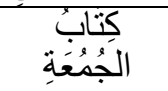 & 11 \\
\hline --- & 1 & --- & 1 & --- & 1 & --- & 1 & 1 & 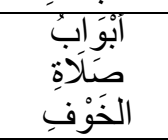 & IT \\
\hline 7 & 1 & --- & V & --- & V & --- & V & $\varepsilon$ & الَبَْوَابَُ & r \\
\hline 1 & --- & --- & 1 & --- & 1 & --- & 1 & 1 & 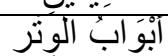 & $1 \varepsilon$ \\
\hline r & --- & --- & r & 1 & $r$ & --- & $r$ & r & 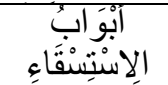 & 10 \\
\hline r & --- & --- & r & --- & r & --- & $r$ & 1 & 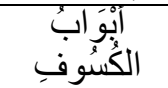 & 17 \\
\hline 1 & $\varepsilon$ & 1 & $\varepsilon$ & --- & 0 & --- & 0 & r & 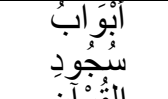 & iv \\
\hline 1 & 1 & --- & r & --- & r & --- & r & r & 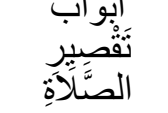 & 11 \\
\hline r & r & r & r & --- & 0 & --- & 0 & r & كتاب & 19 \\
\hline--- & --- & --- & --- & --- & --- & --- & --- & --- & كتاب فضلاة فيل & $r$. \\
\hline 1 & r & --- & r & --- & r & --- & $r$ & r & 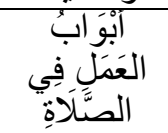 & YI \\
\hline r & --- & --- & r & --- & r & --- & $r$ & r & 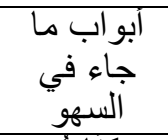 & Yr \\
\hline 9 & r & 1 & 11 & --- & 19 & $r$ & $r r$ & 11 & الَكَنابابُْ & r \\
\hline $7 r$ & rq & 11 & $\Lambda \varepsilon$ & $r$ & $9 V$ & $\varepsilon$ & 1.1 & $7 \pi$ & جموع & \\
\hline
\end{tabular}




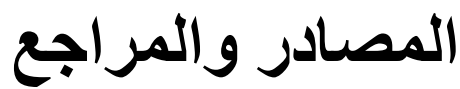

•• الإسنوي، عبد الرحيم بن الحسن بن علي الشافعيّ. "الهداية إلى أوهام الكفاية".

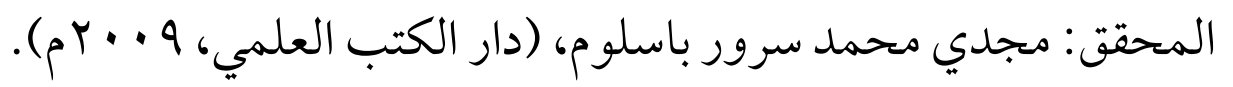

• الأصبحي، مالك بن أنس بن مالك بن عامر المدني. "الموطأ". صححه ورقمه وخرج أحاديثه وعلق عليه: محمد فؤاد عبد الباقي، (بيروت: دار إحياء التراث

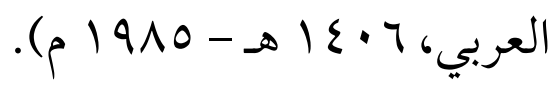

• البخاري، محمد بن إسماعيل بن إبراهيم بن المغيرة. "التاريخ الأوسط". المحقق: محمود إبراهيم زايد، (طا، حلب، القاهرة: دار الوعي ، مكتبة دار التراث،

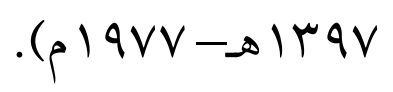

• البخاري، محمد بن إسماعيل أبو عبد الله. "رفع اليدين في الصلاة". وبهامشه جلاء العينين بتخريج روايات البخاري في جزء رفع اليدين، المحقق: بديع الدين

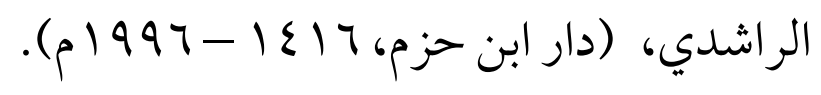

•• البزار، أبو بكر أحمد بن عمرو. "مسند البزار". المحقق: محفوظ الرحمن زين الله

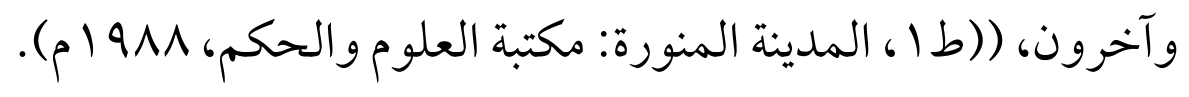

•) بابن بطال، أبو الحسن علي بن خلف. "شرح صحيح البخاري". تحقيق: أبو تميم

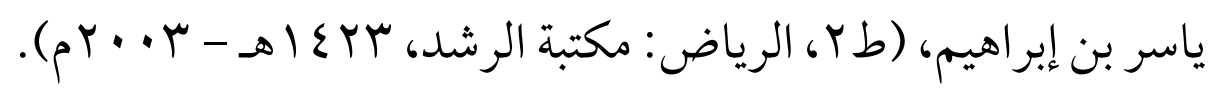

•• البيهقي، أبو بكر أحمد بن الحسين. "مناقب الشافعي" المحقق: السيد أحمد صقر،

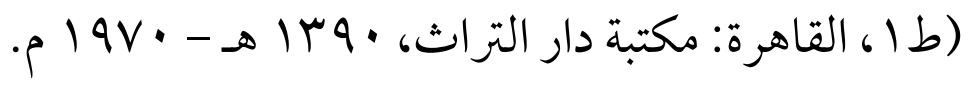

بـالبيقي، أحمد بن الحسين بن علي. "السنن الكبرى". المحقق: محمد عبد القادر

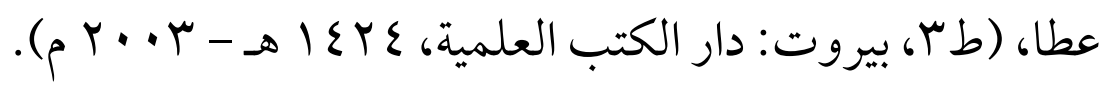


ثخ الترمذي، محمد بن عيسى بن سَوْرة. "سنن الترمذي"، تحقيق وتعليق: أحمد محمد شاكر وآخرون، (ط ץ : مصر، شركة مكتبة ومطبعة مصطفى البابي الحلبي، 90 باهـ

$$
\text { ( ) } 1970-
$$

* ابن جماعة، محمد بن إبراهيم بن سعد ـ "المنهل الروي في مختصر علوم الحديث النبوي" المحقق: د. محيي الدين عبد الرحمن رمضان، (ط ب: دمشق، دار الفكر، . (هـ * ابن حجر، أحمد بن علي العسقلاني . "إتحاف المهرة بالفوائد المبتكرة من أطراف العشرة"، تحقيق : مركز خدمة السنة والسيرة ، بإشراف د زهير بن ناصر الناصر (راجعه ووحد منهج التعليق والإخراج)، (ط ال، المدينة المنورة: مجمع الملك فهد لطباعة المصحف الشريف، 0 (ع 1 هـ - ع 199 م). خابن حجر، أحمد بن علي العسقلاني. "تغليق التعليق على صحيح البخاري" المحقق: سعيد عبد الرحمن موسى القزقي،(طا، عمان: المكتب الإسلامي،

$$
\text { (\$) } 18 \cdot 0
$$

|بن حجر، أحمد بن علي العسقلاني. "التلخيص الحبير في تخريج أحاديث الرافعي

$$
\text { الكبير" (ط (، بيروت: دار الكتب العلمية، } 91 \text { إع (هـ- } 919 \text { (م). }
$$

* ابن حجر، أحمد بن علي العسقلاني. "فتح الباري شرح صحيح البخاري"، رقم كتبه وأبوابه وأحاديثه: محمد فؤاد عبد الباقي، (بيروت: دار المعرفة، وس وسه). •) ابن خزيمة، أبو بكر محمد بن إسحاق النيسابوري. "صحيحُ ابن خُزَيمة". حَققهُ وعَلِّق عَلَيه وَخَرَجَ أحَاديثه وَقََّم له: الدكتور محمد مصطفى الأعظمي، (طس،

$$
\text { عمان: المكتب الإسلامي، ع ع ا هـ - ب... م م). }
$$


•الخطيب، أحمد بن علي بن ثابت البغدادي. "الجامع لأخلاق الراوي وآداب السامع". المحقق: د. محمود الطحان، (الرياض: مكتبة المعارف). •أخطيب، أحمد بن علي بن ثابت البغدادي. "الكفاية في علم الرواية". المحقق: أبو عبدالله السورقي، إبراهيم حمدي المدني، (المدينة المنورة: المكتبة العلمية).

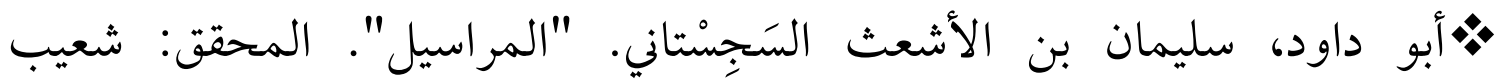
الأرناؤوط، (ط ا، بيروت: مؤسسة الرسالة، 1 • (ع اهـ).

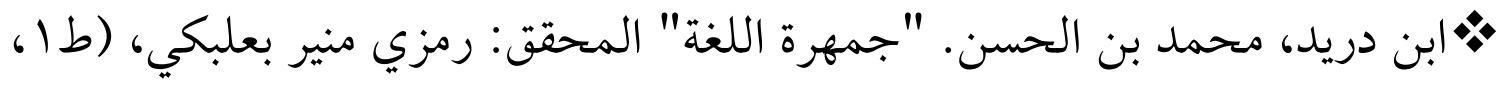

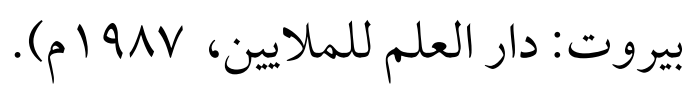

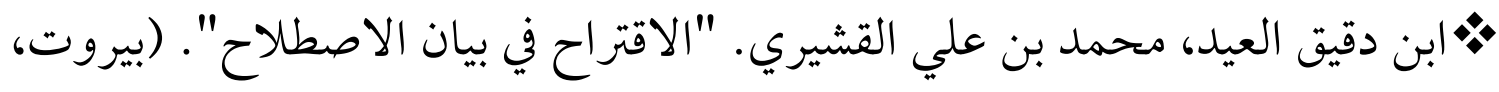

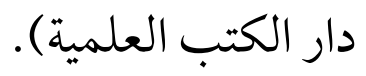
بابن رجب، عبد الرحمن بن أحمد السَلامي الحنبلي. "فتح الباري شرح صحيح

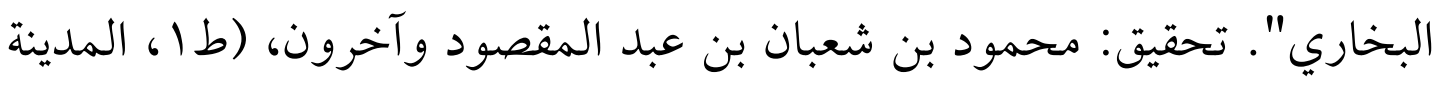

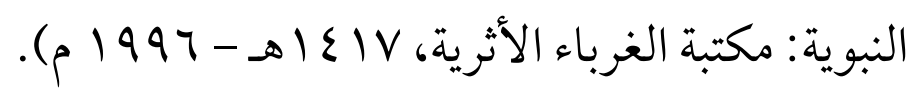

•. الزركشي، محمد بن عبد الله بن بهادر الشافعي. "النكت على مقدمة ابن الصلاح"

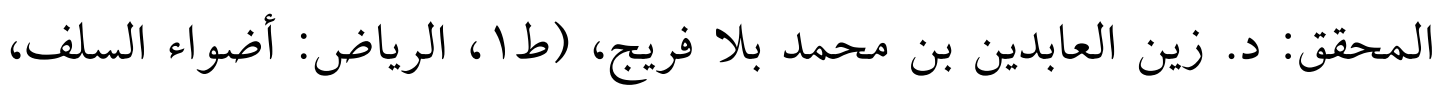

$$
\text { . }
$$

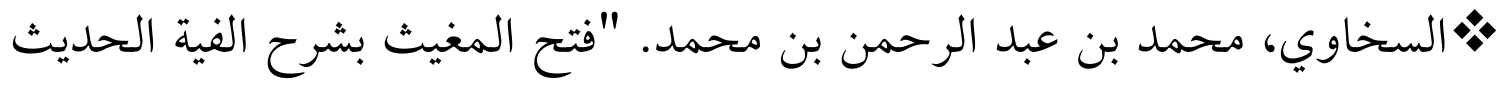

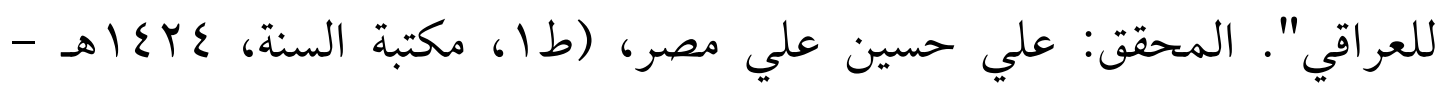

$$
\text { . }
$$

مابن سيده، علي بن إسماعيل المرسي. "المحكم والمحيط الأعظم". المحقق: عبد

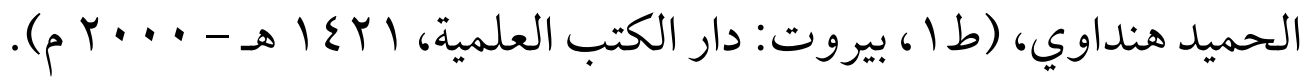


•) ابن أبي شيبة، عبد الله بن محمد بن إبر اهيم بن عثمان العبسي. "الكتاب المصنف في الأحاديث والآثار" المحقق: كمال يوسف الحوت، (الرياض: مكتبة الرشد،

$$
\text { (s) } \varepsilon \cdot q
$$

• صالح، سامية توفيق. "الحديث الموقوف الذى له حكم المرفوع". مجلة جامعة القرآن الكريم والعلوم الإسلامية، جامعة القرآن الكريم والعلوم الإسلامية - مركز

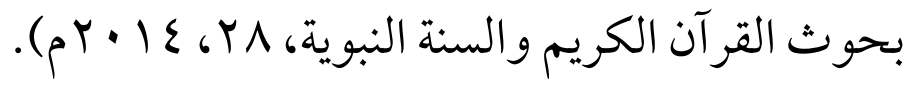

•) الصنعاني، عبد الرزاق بن همام. "المصنف" المحقق: حبيب الرحمن الأعظمي،

$$
\text { (ط (ط، الهند: المجلس العلمي، ب.ع (هـ). }
$$

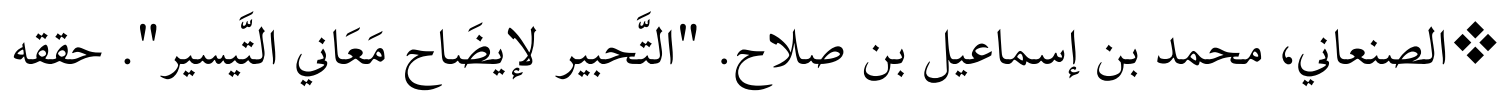

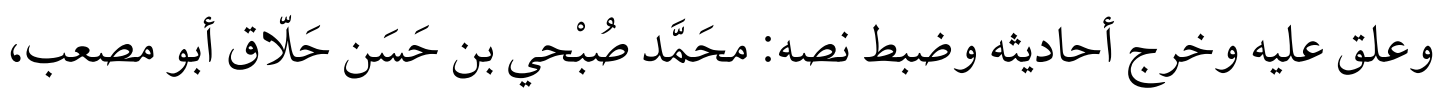

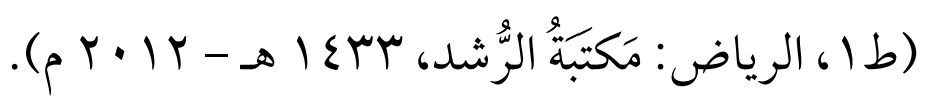

بـ ابن الصلاح، عثمان بن عبد الرحمن، "معرفة أنواع علوم الحديث". المحقق: نور

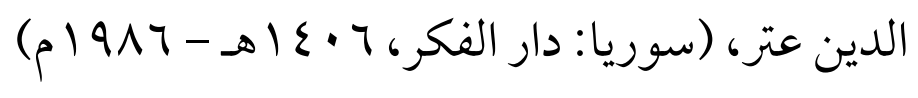

•) الطبراني، سليمان بن أحمد بن أيوب. "مسند الشاميين". المحقق: حمدي ابن

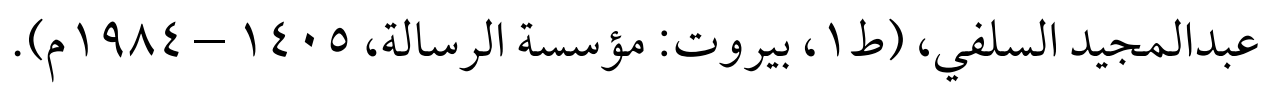

•الطبراني، سليمان بن أحمد بن أيوب. "المعجم الكبير" المحقق: حمدي ابن

$$
\text { عبد المجيد السلفي، (ط Y، القاهرة: مكتبة ابن تيمية). }
$$

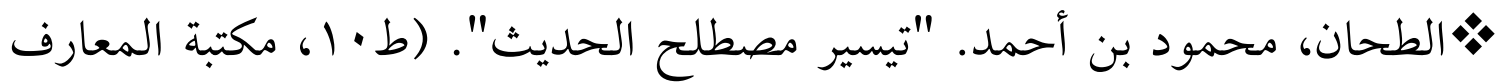

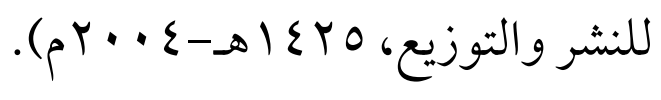

•. الطحاوي، أحمد بن محمد بن سلامة المصري. "شرح معاني الآثار" حققه وقدم له: 
(محمد زهري النجار - محمد سيد جاد الحق) من علماء الأزهر الشريف، راجعه ورقم كتبه وأبوابه وأحاديثه: د. يوسف عبد الرحمن المرعشلي - الباحث بمركز خدمة السنة بالمدينة النبوية، (ط (1، بيروت: عالم الكتب، ع ( ع أهـ، ع9 19 م). • ابن عدي، أبو أحمد الجرجاني. "الكامل في ضعفاء الرجال" تحقيق: عادل أحمد عبد الموجود-علي محمد معوض، شارك في تحقيقه: عبد الفتاح أبو سنة، (ط ا،

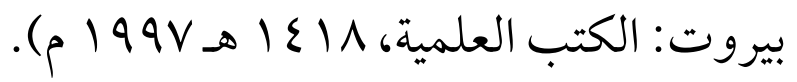
• العراقي، عبد الرحيم بن الحسين بن عبد الرحمن. "التبصرة والتذكرة". المحقق: عبد اللطيف الهميم - ماهر ياسين فحل، (طا، بيروت: دار الكتب العلمية،

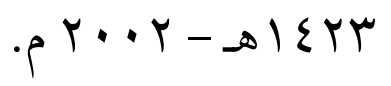
• العطفي، أحمد عيد. "معلقات الإمام البخاري في صحيحه دراسة تحليلية". مجلة كلية الدراسات الإسلامية والعربية بنات- دمنهور، Y( • (1)، IV • بم: صع • ع.

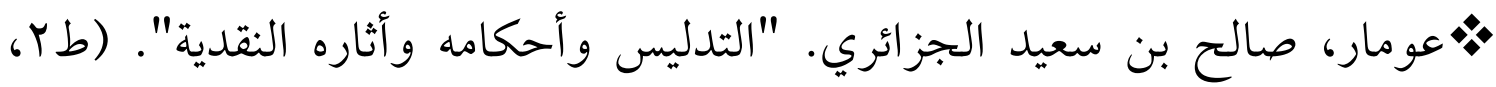

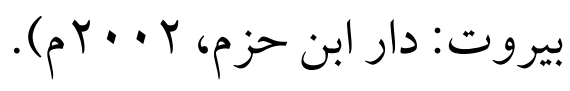

• العيني، محمود بن أحمد بن موسى الحنفي. "عمدة القاري شرح صحيح البخاري". (بيروت: دار إحياء التراث العربي).

• الفراهيدي، الخليل بن أحمد. "كتاب العين" المحقق: د. مهدي المخزومي، د إبراهيم السامرائي، (دار ومكتبة الهالال). •ابن فارس، أحمد بن زكريا الرازي. "معجم مقاييس اللغة" المحقق: عبد السلام

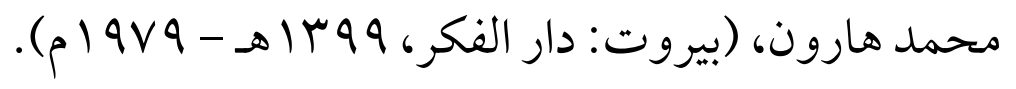
• فضلان، محمد عثمان وآخرون. "الأحاديث الموقوفة التي لها حكم الرفع وحجيتها

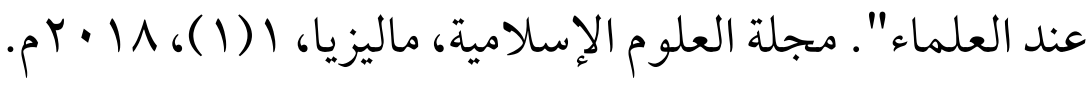


•القرطبي، محمد بن أحمد بن أبي بكر الخزرجي. "الجامع لأحكام القرآن" تحقيق:

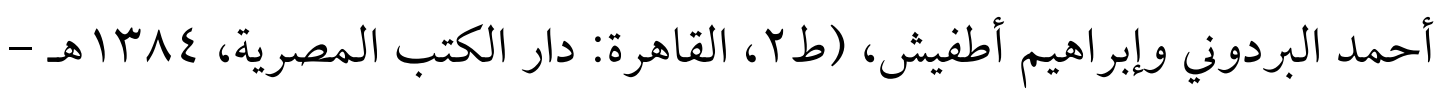

\section{.}

بـالقسلاني، أحمد بن محمد القتيبي المصري. "إرشاد الساري لشرح صحيح

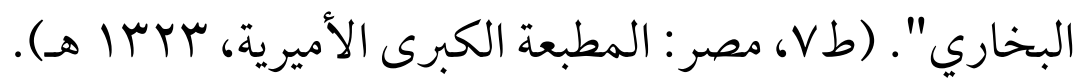

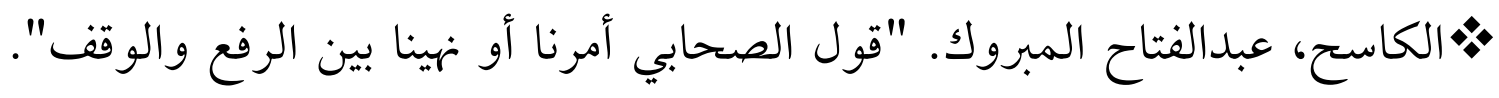

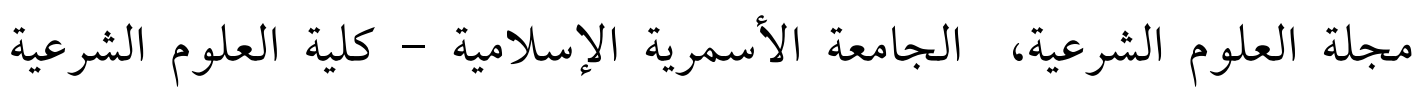

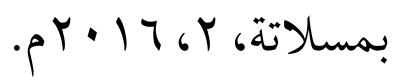

• ابن كثير، إسماعيل بن عمر القرشي الدمشقي. "اختصار علوم الحديث". المحقق:

$$
\text { أحمد محمد شاكر، (ط ז، بيروت: دار الكتب العلمية). }
$$

|بن ماجة، محمد بن يزيد القزويني. "سنن ابن ماجه". تحقيق: محمد فؤاد عبد

$$
\text { الباقي، (دار إحياء الكتب العربية - فيصل عيسى البابي الحلبي). }
$$

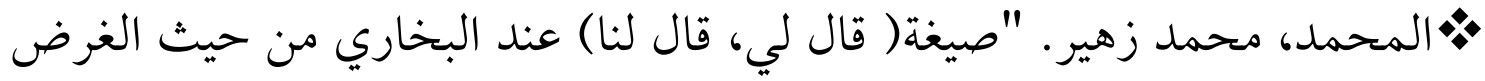

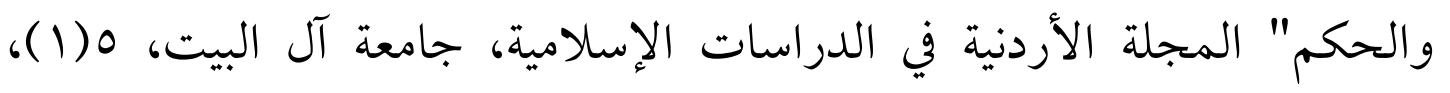

$$
\text { rro }
$$

•) المزي، يوسف بن عبد الرحمن. "تهذيب الكمال في أسماء الرجال". المحقق: د.

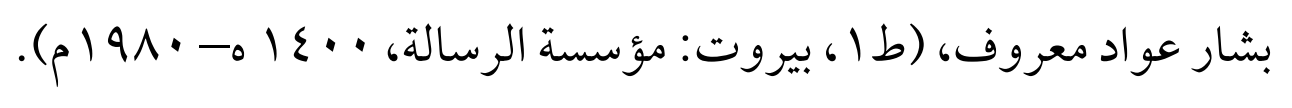

ثابن الملقن، عمر بن علي بن أحمد الشافعي المصري. "البدر المنير في تخريج الأحاديث والأثار الواقعة في الشرح الكبير". المحقق: مصطفى أبو الغيط وعبد الله

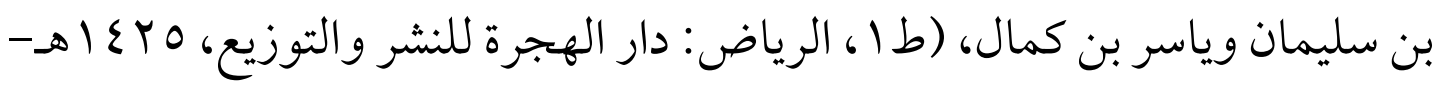

$$
\text { . }
$$


• ابن الملقن، عمر بن علي بن أحمد الشافعي المصري. "المقنع في علوم الحديث". المحقق: عبد الله بن يوسف الجديع، (ط ( ، السعودية: دار فواز للنشر، ساع (هـ). بن منظور، محمد بن مكرم بن علي. "لسان العرب". (طّا، بيروت: دار صادر، $(\rightarrow) \varepsilon) \varepsilon$ • النووي، يحيى بن شرف. "المجموع شرح المهذب". (دار الفكر) ). * النووي، يحيى بن شرف. "المنهاج شرح صحيح مسلم بن الحجاج". (ط (ط، بيروت: دار إحياء التراث العربي، بوس(ه). 


\section{Bibliography}

Al-Asnawi, Abdul Rahim bin Al-Hassan bin Ali Al-Shafei. "Guidance to illusions of sufficiency." The investigator: Majdi Muhammad Surur Baslum, (Dar Al-Kutub AlAlami, 2009 AD).

* Al-Asbahi, Malik bin Anas bin Malik bin Amer Al-Madani. Al-Muwatta '. Corrected, numbered, hadiths, and commented on it: Muhammad Fuad Abd al-Baqi (Beirut: Arab Heritage Revival House, 1406 AH - 1985 CE).

* Prince, Muhammad bin Ismail bin Salah al-San `ani. Inking to clarify the meanings of facilitation. He investigated it, commented on it, produced his hadiths, and set its text: Muhammad Sobhi bin Hassan Hallaq Abu Musab, (1st ed., Riyadh: Al-Rushd Library, 1433 AH - 2012 AD).

* Al-Bukhari, Muhammad bin Ismail bin Ibrahim bin al-Mughira. Middle History. Investigator: Mahmoud Ibrahim Zayed, ((1st floor, Aleppo, Cairo: House of Consciousness, Dar Al Turath Library, 1397-1977).

* Bukhari, Muhammad bin Ismail Abu Abdullah. "Raise the hands during prayer." With his margin, the eyes are clear by graduating the narrations of Al-Bukhari in the section on raising the hands, the investigator: Badi Al-Din Al-Rashidi, (Dar Ibn Hazm, 1416 - 1996 AD).

* Al-Bazar, Abu Bakr Ahmed bin Amr. "The Bazar Rack". The investigator: Mahfouz AlRahman Zain Allah and others, ((ed1, Medina: Library of Science and Governance, 1988 AD).

* Ibn Battal, Abu Al-Hassan Ali bin Khalaf. Explanation of Sahih al-Bukhari. Edited by: Abu Tamim Yasser bin Ibrahim, (2nd Edition, Riyadh: Al-Rashed Library, $1423 \mathrm{AH}$ 2003 AD).

* Al-Bayhaqi, Abu Bakr Ahmed bin Al-Hussein. "The Virtues of the Shafi'i" The verifier: Mr. Ahmed Saqr, (1st Edition, Cairo: Dar Al Turath Library, 1390 AH - 1970 AD.)

* Al-Bayhaqi, Ahmed bin Al-Hussein bin Ali. Al-Sunan Al-Kubra. The investigator: Muhammad Abdel Qader Atta, (3rd edition, Beirut: Dar Al-Kotob Al-Ilmiyya, 1424 AH - 2003 AD).

* Al-Tirmidhi, Muhammad bin Isa bin Surah. Sunan al-Tirmidhi, investigation and commentary by Ahmad Muhammad Shaker et al. (2nd Edition: Egypt, Mustafa alBabi al-Halabi Library and Press Company, 1395 AH - 1975 CE)

* Ibn Jama`ah, Muhammad bin Ibrahim bin Saad. "Al-Manhal Al-Nari in the Summary of the Sciences of the Prophetic Hadith." The investigator: Dr. Muhyiddin Abd alRahman Ramadan, (i 2: Damascus, Dar al-Fikr, 1406 AH).

* Ibn Hajar, Ahmed bin Ali Al-Asqalani. "Contouring the skill with innovative benefits from the ten edges", edited by: Sunnah and Biography Service Center, under the supervision of Dr. Zuhair bin Nasser Al-Nasser (reviewed and unified the commentary and output method), (1st Edition, Madinah: King Fahd Complex for the Printing of the Holy Quran, 1415 AH - 1994 AD) .

* Ibn Hajar, Ahmed bin Ali Al-Asqalani. "Close Commentary on Sahih Al-Bukhari" The investigator: Saeed Abdul-Rahman Musa Al-Qazqi, (First Edition, Amman: The Islamic Office, $1405 \mathrm{AH}$ ). 
Ibn Hajar, Ahmed bin Ali Al-Asqalani. "Al-Talebaz Al-Lubin in the Graduation of Hadiths of Al-Rafa'i Al-Kabeer" (ed. 1, Beirut: Dar Al-Kutub Al-Ulmiah, 1419 AH 1989 AD)

* Ibn Hajar, Ahmed bin Ali Al-Asqalani. Fath al-Bari Sharh Sahih al-Bukhari, the number of his books, chapters and hadiths: Muhammad Fuad Abd al-Baqi (Beirut: Dar al-Maarifa, $1379 \mathrm{AH}$ ).

* Ibn Khuzaymah, Abu Bakr Muhammad bin Ishaq al-Nisaburi. Saheeh Ibn Khuzaymah. He investigated it, commented on it, published his hadiths, and presented him: Dr. Muhammad Mustafa al-Azami, (3rd Edition, Amman: The Islamic Office, $1424 \mathrm{AH}$ - $2003 \mathrm{AD}$ ).

* Al-Khatib, Ahmed bin Ali bin Thabit Al-Baghdadi. Al-Jami 'for the narrator's ethics and the manners of the listener. Investigator: Dr. Mahmoud Al-Tahan (Riyadh: AlMaarif Library).

* Al-Khatib, Ahmed bin Ali bin Thabit Al-Baghdadi. Sufficiency in the science of the novel. Investigator: Abu Abdullah Al-Surqi, Ibrahim Hamdi Al-Madani, (Medina: the Scientific Library).

* Abu Dawud, Sulaiman bin Al-Ash'ath Al-Sijjasani. Correspondents. The investigator: Shuaib Al-Arna 'out, (1st ed., Beirut: Foundation for the message, 1408 A.H.).

* Ibn Duraid, Muhammad Ibn Al Hassan. "The Language Population", investigator: Ramzi Munir Baalbaki, (1st Edition, Beirut: Dar Al-Alam Al-Malayn, 1987 AD).

* Ibn al-Eid flour, Muhammad bin Ali al-Qushayri. "The suggestion in a statement of convention." (Beirut, Dar Al-Kutub Al-Ilmiyya).

* Ibn Rajab, Abdul Rahman bin Ahmed Al Salami Al Hanbali. Fath al-Bari, explanation of Sahih al-Bukhari. Edited by: Mahmoud bin Shaaban bin Abdul Maqsoud and others, (First Edition, Al-Madinah Al-Nabawiyyah: Al-Ghurabaa Archaeological Library, 1417 AH - 1996 AD).

* Al-Zarkashi, Mohammed bin Abdullah bin Bahadur Al-Shafei. Jokes about the introduction of Ibn Al-Salah. The investigator: Dr. Zain Al-Abidin Bin Muhammad Without Freej, (1st Edition, Riyadh: Adwaa Al-Salaf, 1419 AH - 1998 AD).

* Al-Sakhawi, Mohammed bin Abdul Rahman bin Mohammed. "Fath al-Maghith explains the millennial hadith to the Iraqi." Investigator: Ali Hussein Ali, Egypt (1st Edition, Sunna Library, 1424 AH - 2003 AD).

* The son of his master, Ali bin Ismail Al-Morsi. "The arbitrator and the greatest ocean." The investigator: Abdel Hamid Hindawi, (1st ed., Beirut: Dar Al-Kotob AlIImiah, 1421 AH - 2000 AD).

* Ibn Abi Shaybah, Abdullah bin Muhammad bin Ibrahim bin Othman al-Absi. "The Compiled Book on Hadiths and Archeology." The investigator: Kamal Yusef al-Hout (Riyadh: Al-Rashed Library, $1409 \mathrm{AH}$ )

* Saleh, Samia Tawfiq. "The mawqoof hadith which has the ruling on the marfoo '. Journal of the University of the Noble Qur'an and Islamic Sciences, University of the Noble Qur'an and Islamic Sciences - Center for Research of the Noble Qur'an and Sunnah, 28, 2014). 


\section{فهرس الموضوعات}

$r \cdot \varepsilon r$

موجز عن البحث

$r \cdot\{0$

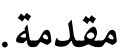

$r \cdot 0 \cdot$

تمهيد : الحديث الموقوف ( تعريفه، وأهميته ) .

$r \cdot 0 \cdot$

أولاً: تعريف الحديث الموقوف لغة واصطلاحًا .

$r \cdot 01$

ثانيًا: أهمية معرفة الموقوف

$r \cdot 0 \varepsilon$

المبحث الأول : المقاصد العامة لذكر البخاري للحديث الموقوف ..

المبحث الثاني : أنواع الموقوف من حيث الظهور والخفاء ومنهج البخاري فيه .. • · · ب

$r \cdot T \cdot$ المطلب الأول : أن يكون الحديث الموقوف جليًا: .

$r \cdot 71$ المطلب الثاني : أن يكون الحديث الموقوف خفيًا .

المبحث الثالث : أنواع الموقوفات عند البخاري من حيث الاتصال و التعليق ... بح · ب المطلب الأول : ما رو اه البخاري موقوفًا مسندًا .......................................

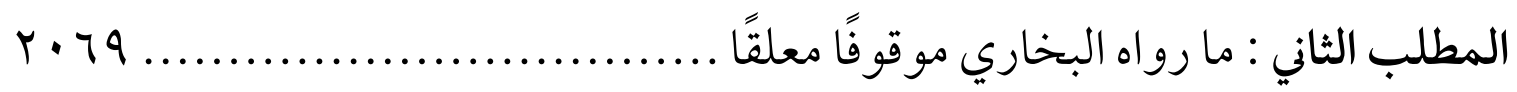
$r \cdot V \varepsilon$ المطلب الثالث : ما رواه البخاري بصيغة قال لنا ... $r \cdot V T$ المبحث الرابع : منهج البخاري في سياقة الموقوفات المطلب الأول : جمع البخاري لأكثر من حديث موقوف والمتن والإسناد واحد VT PT المطلب الثاني : جمع البخاري للموقوفات عن الصحابي الواحد وهي أحاديث متفرقة

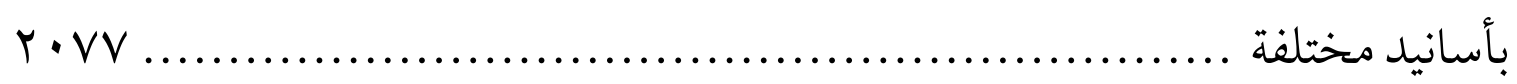
المطلب الثالث : جمع البخاري للموقوفات عن عدة صحابة وهي أحاديث متفرقة بأسانيد مختلفة . 
المبحث الخامس : العلاقة بين الحديث الموقوف وبين ترجمة الباب والحديث

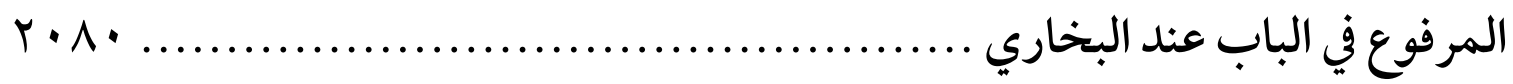

المطلب الأول : العلاقة بين الحديث الموقوف وترجمة الباب .................... • • • المطلب الثاني : العلاقة بين الحديث الموقوف والحديث المرفوع في الباب ..... rی • r

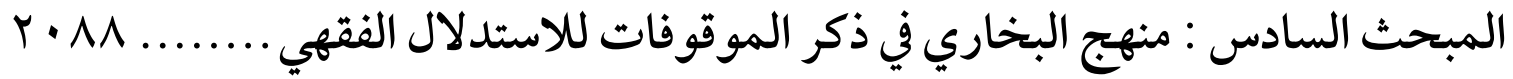
$r \cdot 91$ الخاتمة و النتائج $r \cdot 9 r$ ملحق: إحصائيات الموقوفات في صحيح البخاري في كل كتاب . $r \cdot 9 \varepsilon$ المصادر والمراجع $r \cdot 1$ Bibliography $r \cdot r$ فهرس الموضوعات . 